REVISTA DE DERECHO UNED, NÚM. 26, 2020

\title{
ANÁLISIS DE LA PROBLEMÁTICA DE LAS INFRACCIONES POR FALTA DE INGRESO TRIBUTARIO
}

\section{ANALYSIS OF THE PROBLEM OF INFRACTIONS DUE TO LACK OF TAX REVENUE}

\section{IVÁN PÉREZ JORDÁ}

Funcionario de Administración Local con habilitación de carácter nacional. Doctor en Derecho Financiero y Tributario. Profesor Asociado de Derecho Administrativo en la Universidad de Valencia. Licenciado en Ciencias Políticas. Doctorando en Filosofía y Letras en la UNED.

Resumen: El presente artículo se analiza detenidamente la problemática que plantean los supuestos infractores consistente en dejar de ingresar la deuda tributaria.

Abstract: The present article analyses in detail the problem posed by the alleged offenders consisting in the failure to pay the tax debt.

Palabras clave: Prescripción, cómputo, dies a quo, infracción, dejar de ingresar, regularización encubierta.

Keywords: Prescription, computation, dies a quo, infraction, failure to pay, concealed adjustment.

Sumario: I. Introducción. II. El cómputo del plazo prescriptivo de las infracciones tributarias. III. La consumación del plazo prescriptivo de las infracciones tributarias. IV. La prescripción de la infracción tributaria consistente en dejar de ingresar la deuda tributaria. 4.1. Supuesto de hecho de la prescripción de la infracción tributaria consistente en dejar de ingresar la deuda tributaria, como infracción que causa o puede causar perjuicio económico. 4.2. Naturaleza del tipo infractor. 3.3. Exención por regularización. 4.4. 
Infracción por incumplimiento de la obligación de retener, de efectuar pagos a cuenta o fraccionados. 4.5. Obtención de devolución tributaria solicitada indebidamente. 4.6. La regularización tributaria encubierta. V. Otros supuestos de hecho infractores, consistentes en dejar de ingresar la deuda tributaria, no previstos en la LGT. VI. Circunstancias calificativas de la infracción. VII. Compatibilidades infractoras. VIII. Conclusiones.

Recepción original: 8-1-2020

Aceptación original: 1-6-2020

\section{INTRODUCCIÓN}

El presente artículo pretende analizar la regulación de los diferentes supuestos infractores que tengan por objeto el dejar de ingresar una deuda, estudiando cada supuesto de hecho, así como la viabilidad de la exoneración de la responsabilidad infractora por regularización, sus compatibilidades con otros supuestos infractores, y la posible aplicación en cada caso de las circunstancias agravantes o atenuantes, todo ello bajo el paraguas del instituto de la prescripción de la infracción tributaria, por lo que pondremos especial énfasis en el cómputos de los plazos inicial y final.

\section{EL CÓMPUTO DEL PLAZO PRESCRIPTIVO DE LAS INFRACCIONES TRIBUTARIAS}

Cuando de prescripción se trata, los plazos establecidos son normalmente por meses o por años. Tradicionalmente, en todos los sectores de nuestro ordenamiento jurídico, el cómputo de los plazos señalados por meses o año se ha venido haciendo de fecha a fecha, sin exclusión de los días inhábiles, tal y como señala el artículo $5.1^{\circ}$ del Código Civil.

En relación con este aspecto son varias las cuestiones que es preciso abordar para determinar con exactitud cómo opera el dies a quo de la prescripción en el ámbito de las infracciones tributarias.

En primer lugar, es preciso concretar cómo ha de computarse el plazo de prescripción de cuatro años en el ámbito de la responsabilidad derivada de la comisión de una infracción tributaria; este aspecto suscita, entre otras, cuestiones tan interesantes como cuál es el momento a partir del que comienzan a correr los plazos de prescripción; cómo se determina ese momento en cada supuesto infractor; en qué medida hay que aplicar el plazo de prescripción de cuatro años 
con carácter retroactivo; e incluso como ya hemos tratado, de qué modo se computan los plazos de prescripción de la responsabilidad derivada de una conducta en función de que ésta se califique como criterio de graduación de la sanción o como supuesto de infracción.

El artículo $189.2^{\circ}$ de la LGT establece que el plazo de prescripción para imponer sanciones tributarias será de cuatro años y comenzará a contarse «desde el momento en que se cometieron las correspondientes infracciones ${ }^{1} »$, sin que la clandestinidad u ocultación ${ }^{2}$ en la infracción sea óbice para el inicio de su prescripción,

1 LAMOCA PÉREZ critica la reducida regulación frente a la exhaustiva de los artículos 66 a 70 LGT, y así lo podemos ver en la ausencia de normas sobre el inicio del plazo de prescripción, y en la deficiente, por escasa, referida a su interrupción. LAMOCA PÉREZ,C.: Infracciones y sanciones tributarias. Análisis crítico del nuevo sistema de infracciones y sanciones en la Ley General Tributaria, CEF, Madrid, 2005, pág. 215; El plazo deberá computarse a partir del día que la actividad del particular se haya realizado. Ahora bien, tal actividad ha de constituir el presupuesto suficiente para que pueda ejercitarse la potestad administrativa de que se trata. AGUADO I CUDOLÂ, V.: Prescripción y caducidad en el ejercicio de potestades administrativas, Marcial Pons, Madrid,1999, pág. 36; Y ello con independencia de que los efectos de la infracción se manifiesten o no de manera periódica. STSJ Aragón de 27 de febrero de 2001; En el ámbito penal, frente al sistema vigente, en el que el dies a quo -en general- se computa desde el momento de su comisión-, RAGUÉS estima que el modelo que se decanta por el día de trascendencia pública es una opción a tener en cuenta, aunque no parece aportar muchas ventajas si se lo compara con el sistema vigente. Con todo, no debe descartarse la conveniencia de esta posibilidad si en un determinado sector de delincuencia se detecta un número excesivamente elevado de impunidades por prescripción, que pueda afectar negativamente al correcto cumplimiento de la función del sistema penal. En tales casos nada se opone a que se establezca algún tipo de regla ad a.C. que retrase el inicio del cómputo de los plazos hasta el momento de conocimiento (o conocimiento potencial) de la víctima o colectividad...como en el caso de los delitos con víctimas menores de edad. RAGUÉS I VALLÉS, R.: La prescripción penal: fundamento y aplicación, Atelier, Barcelona 2004, págs. 149-150.

2 Con la LGT, sin embargo, a la mitad de las infracciones tributarias concretamente, las previstas en los arts. 194, 195, 196, 197, 200, 202, 205 y 206- nunca se les va a poder incrementar las sanciones por la concurrencia de algún criterio de graduación. Y lo cierto es que no parece existir un criterio que justifique esta diferencia de trato. Desde luego, la justificación de esta diferenciación no reside en la clase de infracción, porque hay infracciones leves a las que sí se le aplican criterios de graduación (es el caso de la infracción por el incumplimiento de los deberes de facturación o documentación prevista en el art. 201.4); infracciones graves a las que no se le aplican criterios de graduación [así, solicitar indebidamente devoluciones (art. 194.1), determinar o acreditar improcedentemente partidas positivas o negativas o créditos tributarios aparentes (art. 195), cualquiera de las dos infracciones que pueden cometer las entidades sometidas al régimen de imputación de rentas (arts. 196 y 197), el incumplimiento de obligaciones contables y registrales (art. 200), o, en fin, el incumplimiento de los deberes de las entidades de crédito en relación con el NIF (art. 202.2)]; e infracciones muy graves para las que tampoco está prevista en ningún caso el incremento de la sanción por la concurrencia de criterios de graduación (es el caso del incumplimiento del deber de comunicar correctamente datos al pagador

(C) UNED. Revista de Derecho UNED, núm. 26, 2020 


\section{lo que en la práctica podría conducir a la imprescriptibilidad de las}

de rentas sometidas a retención o ingreso a cuenta, cuando el obligado tributario no tenga la obligación de presentar autoliquidación que incluya dichas rentas, tipificado en el art. 205.3). Tampoco reside en el perjuicio económico ocasionado a la Hacienda Pública, porque la cuantía de lo dejado de ingresar o de la devolución indebidamente obtenida puede ser muy elevada y, sin embargo, si la infracción es leve (porque no concurre ninguno de los criterios de calificación del art. 184 LGT), no se aplicarán las agravantes de reincidencia y perjuicio económico para la Hacienda Pública previstas en los apartados 3 y 4 de los arts. 191, 192 y 193 LGT. En fin, ni siquiera la falta de aplicación de los criterios de graduación a algunas infracciones responde siempre a la naturaleza de esta última porque existen criterios como el de comisión repetida de infracciones tributarias que, en principio, no resulta incompatible con ningún tipo infractor y, sin embargo, como veremos, sólo está previsto para las infracciones de los arts. 191, 192, 193, 199, apartados 4 y 5, y 204,.. En efecto, como hemos expuesto antes, la LGT, a diferencia de la LGT 1963, al definir cada uno de los comportamientos infractores especifica qué criterios de graduación -y cuáles únicamente- les resultan aplicables... Sentado lo anterior, debemos recordar que sólo es posible aplicar los criterios de graduación previstos en el art. 187.1 LGT para aquellas infracciones en las que se establezca expresamente esta posibilidad. Pues bien, la LGT (apartados 3 y 4 , in fine, de los arts. 191, 192 y 193; y arts. 199.6 y 204.2), sólo contempla la posibilidad de aplicar la agravante de reincidencia en relación con cinco tipos infractores LGT... si bien debe tenerse en cuenta que en las infracciones de los arts. 191, 192 y 193 LGT 2003 el criterio de graduación que examinamos se aplicará únicamente cuando las infracciones se califiquen como graves o muy graves... Por último, interesa también precisar que, a diferencia de lo que establecía la normativa derogada (en particular, el art. 17.2 del RD 1930/1998), para la aplicación del criterio de graduación que examinamos basta con que las infracciones sancionadas con anterioridad sean de la misma naturaleza, sin que sea preciso que los comportamientos descritos en los arts. 191, 192 y 193 LGT hayan tenido lugar en relación con el mismo tributo o un tributo distinto pero gestionado por la misma Administración tributaria... los criterios de graduación son el modo de plasmar el principio constitucional de proporcionalidad, principio que obliga a adecuar la magnitud de la sanción a la gravedad de la conducta (3). Y es evidente que esta no es la función que cumple la reducción por acuerdo o conformidad, dado que, una vez cometida la infracción, cuando ésta se ha detectado por la Administración tributaria (es decir, no estamos hablando del supuesto del art. 27 LGT) y ha concluido el procedimiento de aplicación de los tributos, la conformidad con la liquidación o la sanción nada suma o resta a la gravedad de la conducta infractora. Como es de sobra conocido, la reducción por acuerdo o conformidad -como señaló en su día el Tribunal Constitucional- no constituye más que un «una técnica cuyo designio es lograr una simplificación y celeridad en los procedimientos tributarios» (4), un modo de "conseguir el objetivo de agilización de las actuaciones y disminución de la litigiosidad»... la LGT integra el acuerdo o conformidad del obligado tributario entre los criterios de graduación del art. 187....A nuestro juicio, no se compadece con el principio de proporcionalidad que para determinar el porcentaje de incremento de la sanción por las infracciones de los arts. 191, 192 y 193 LGT se tenga en cuenta exclusivamente la calificación de la infracción que se toma como antecedente, con independencia de la cuantía del perjuicio ocasionado a la Hacienda Pública... El art. 187.2 LGT, finalmente, establece que «[1] os criterios de graduación son aplicables simultáneamente», entendiendo como criterios de graduación, como hemos dicho, tanto los que efectivamente pueden ser considerados como tal como el acuerdo o conformidad del interesado. Dada la claridad de la norma en este punto, baste aquí con hacer dos precisiones. La primera de ellas es que no a todas las infracciones tipificadas en los arts. 191 a 206 LGT le son aplicables alguno de los criterios de graduación o 


\section{infracciones ${ }^{3}$.}

El momento de la comisión de las infracciones, tal y como se ha expuesto en líneas precedentes, coincide con el de la concurrencia de todos los elementos de la conducta que se tipifica como tal, y precisamente, en ese instante, se produce la consumación ${ }^{4}$ del ilícito. El día inicial en el cómputo de la prescripción viene determinado por un hecho extraprocedimental como es la fecha en que se cometió la infracción $n^{5}$. Ahora bien, la consumación de la infracción se pone de manifiesto en momentos distintos en función de que la conducta tipificada consista en una acción o en una conducta omisiva y que exija o no la consecución de un resultado ${ }^{6}$. Así las infracciones de

reducción de las sanciones contenidos en el art. 187.1 LGT o en el resto de la LGT. En particular, no admiten agravación o atenuación alguna de la sanción impuesta las infracciones de los arts. 195, 196, 197, 198, apartados 4 a 6, 200, 202, 205 y 206, LGT; y no admiten la reducción por acuerdo o conformidad las infracciones contenidas en los arts. 198 a 206 LGT. La segunda precisión que queremos recordar es que en las infracciones en las que está legalmente prevista la graduación o/y reducción de la sanción, no resultan aplicables todos y cada uno de los criterios previstos en la Ley, sino únicamente aquellos que aparecen expresamente autorizados en el precepto en el que se tipifica la infracción. De manera que: - A las infracciones recogidas en los arts. 191, 192 y 193 LGT, sólo se les aplican los criterios de la comisión repetida de infracciones y de perjuicio económico para la Hacienda Pública, así como la reducción por acuerdo o conformidad... De lo anterior se deduce que cuando el art. 187.2 LGT precisa -a nuestro juicio, innecesariamente que los criterios de graduación serán aplicables simultáneamente, sólo puede estar refiriéndose a las sanciones por las infracciones de los arts. 191, 192, 193, 194, 199 (únicamente a la consistente en la presentación incorrecta de declaraciones exigidas con carácter general en cumplimiento de la obligación de suministro de información) y 203.5 LGT.AGUALLO AVILÉS, A. y. BUENO GALLARDO,E.: «Los criterios de graduación de las sanciones tributarias establecidos en la LGT», Estudios y notas, Crónica Tributaria, núm. 134, 2010, págs. 7, 11, 12, 13, $15,17,19,35$.

3 LOZANO CUTANDA,B.: La extinción de las sanciones administrativas y tributarias, Marcial Pons,Madrid,1990, págs.212-213.

4 No cabe excluir la culpabilidad porque el recurrente ha dejado de ingresar parte de la cuota correspondiente. Infracción tributaria muy grave: servirse de facturas sin el respaldo de servicios realmente prestados, pone de manifiesto una conducta voluntaria y tendente a reducir el ingreso tributario (STSJ Madrid, Sala de lo Contencioso-Administrativo, Sec. 5. ${ }^{\text {a }}$ 1.6.2017)

5 DE DIEGO DÍEZ, L.A.: Prescripción y caducidad en el Derecho administrativo sancionador, Bosch, Barcelona, 2006, pág.46.

6 MEMENTO PRÁCTICO FRANCIS LEFEVBRE. Inspección de Hacienda 2008-2009, Francis Lefevbre, Madrid,2008, pág. 325. El manual establece «la prescripción de la acción para imponer sanciones tributarias se regula de forma separada de la prescripción del derecho de la Administración a determinar la deuda tributaria mediante la oportuna liquidación, incluso tratándose de las infracciones causantes del perjuicio económico tipificadas en la LGT. No obstante el plazo de prescripción en ambos casos es el de cuatro años y el inicio del cómputo de dicho plazo coincide, dado que la infracción se considera cometida no cuando se presenta la autoliquidación o declaración incorrecta, sino cuando finaliza el plazo de declaración presentada evitando incurrir en los tipos definidos en la LGT». Sólo en el supuesto 
acción consisten en una conducta positiva que supone la contravención de una norma prohibitiva, cuyo momento de consumación dependerá de la estructura del tipo infractor. Las infracciones de omisiones, se configuran como conductas negativas, que infringen una norma preceptiva, entre las que se incluyen aquellas descritas por la ley con la expresión 'retraso', 7 'negativa' o similares, aunque no es la negativa o el retraso en sí mismo considerado lo que comporta la violación de la norma, sino la omisión del acto o de los actos que la norma misma ordena. La omisión sancionable consiste en un voluntario $^{8}$ no hacer concreto, constituyendo sus notas esenciales la naturaleza positiva del precepto y radicar el hecho delictivo en el mismo acto voluntario de inacción. Esta categoría integra las infracciones atinentes a la desobediencia o incumplimiento de los ciudadanos

de obtención indebida de devoluciones (art. 193 LGT) no se inician en el mismo momento el plazo de prescripción del derecho de la administración a determinar la deuda tributaria y el de su derecho a sancionar la infracción cometida pues, normalmente, no coincide el momento en que se obtiene la devolución con la finalización del plazo voluntario de declaración; Por su parte, DÍEZ OCHOA indica que "la Administración tributaria entiende que en los casos de los artículos 191 a 198 LGT, tanto si se presenta declaración como si ésta no se presenta, la infracción se entiende cometida el último día del período reglamentario de presentación (excepto la infracción tipificada en el art. 193 L. 58/2003, y en el art. 194 LGT si se presenta la autoliquidación fuera del plazo de declaración). En este sentido la Sentencia del TS, de fecha 26 de julio de 1999. En el caso de que el obligado tributario hubiera presentado la declaración o autoliquidación, se entiende cometida igualmente. El último día del plazo reglamentario de presentación de la correspondiente declaración o autoliquidación. En este sentido la Sentencia del TS de fecha 6 de noviembre de 2000 (se consuma en el momento en que expira el plazo legal voluntario para realizar el pago. Antes no cabe hablar de consumación, pues el sujeto aún podría desistir voluntariamente verificando el pago a través de una declaración complementaria. DÍEZ OCHOA, J.M. Derecho Tributario Sancionador. Comentarios y casos prácticos, CEF, Madrid, 2005, pág. 249.

7 Retraso en la imputación temporal entre periodos de declaración mensual o trimestral de cantidades a ingresar (decalaje) [RTEAC, Vocalía 6. $\left.{ }^{a}, 19-5-2010\right]$.

8 La aplicación de la renuncia a la exención de IVA, no procediendo ésta, supone una conducta, por parte de la entidad obligada tributaria, nada diligente en cuanto que no viene amparada por una interpretación razonable de la norma aplicable. Se aprecia culpabilidad en la conducta de la entidad obligado tributario al poder considerarla, cuando menos, como negligente, en tanto en cuanto que autoliquidó el tributo consignando una tipo de gravamen inferior al que resultaba procedente (STSJ Aragón, Sala de lo Contencioso-Administrativo, Sec. 2. a, 17.5.2017). Concurre culpabilidad porque no se han declarado todos los ingresos obtenidos y se han contabilizado gastos no devengados y gastos inexistentes, lo que solo se puede producir de una manera consciente y voluntaria. El Acuerdo sancionador no carece de falta de motivación sino de motivación errónea por entenderse incorrectos lo argumentos y no ser ciertas las razones fácticas en las que se basa, teniendo que demostrarlo quien lo alega, no siendo así en el presente (STSJ Castilla y León, Burgos, Sala de lo Contencioso-Administrativo, Sec. 2. a, 12.5.2017).Se da el tipo infractor del artículo 191 LGT en el caso de beneficiarios de exenciones y tipos reducidos obligados a presentar autoliquidación que dejan de ingresar la deuda tributaria (RTEAC, Vocalía 12. ${ }^{a}, 21.1 .2016$ ). 
de lo que la ley o la autoridad mandan en concretos casos. Las infracciones de omisión se consumarían en el momento en que el sujeto hubiera debido, lo más tarde, realizar la conducta debida, plazo que partirá en el momento en que debió realizarse la acción que del sujeto se espera9 . Por otra parte, desde el punto de vista del bien jurídico protegido es sabido que algunas infracciones tratan de salvaguardar la lesión efectiva del mismo, mientras que otras se adelantan a ese momento y tratan de evitar su puesta en peligro.

Por este motivo, es conveniente reiterar el significado de los conceptos mencionados $\mathrm{y}$, con apoyo en los mismos, será preciso determinar en qué momento se consuma ${ }^{10}$ cada una de las infracciones que se tipifican ${ }^{11}$ en la LGT, teniendo en cuenta la distinción que esta norma realiza entre infracciones leves, graves y muy graves.

9 MARTÍN CÁCERES,A.F.:La prescripción del crédito tributario, Marcial Pons,Madrid,1994, pág.114.

10 En relación a este punto merece la pena señalar que, conforme a la doctrina del Tribunal Supremo, en las infracciones tributarias consistentes en dejar de ingresar en plazo mediante la falta de presentación de las autoliquidaciones o la presentación de éstas de forma incorrecta (art. 191 LGT) el momento de la consumación varía en función del comportamiento del sujeto infractor: si este no presentó la autoliquidación, la consumación se produce al día siguiente al de la conclusión del plazo para la presentación de la misma; y si la presentó de forma incorrecta, el mismo día de la presentación. Esta es la doctrina que se sienta, concretamente, en las SSTS de 5-5-1993 (RJ 1993\3600), FD 2; de 19-12-1995 (RJ 1995\9869), FD 2; de 12-11-1997 (RJ 1997\9299), FD 2; de 25-2-1998 (RJ 1998\1409), FD 2; y de 4-10-2002 (RJ 2003\907), FD 4. AGUALLO AVILÉS, A. y. BUENO GALLARDO,E.: "Los criterios ...op.cit.”, Estudios y notas, Crónica Tributaria, núm. 134, 2010, pág.18.

11 De la lectura del artículo 25 de la Constitución pueden surgir dudas en relación con el alcance del principio de legalidad en materia de sanciones administrativas, por su parte, el Título IX de la LRJ-PAC[hoy en algunos preceptos de la Ley 39/2015, de 1 de octubre, del Procedimiento Administrativo Común de las Administraciones Públicas -arts. 1.1, 25.1.b, 36.1.h, 53.2, 55.2, 60.2, 61.3, 62, 63, 64, 77.4, 85, 88.7 in fine, 89,90, 96.5, 98.1.b, 98.2, 103.2, 114.1.f 128.2 y DA1.2.c-, y en el Capítulo III del Título Preliminar de la Ley 40/2015, de 1 de octubre, de Régimen Jurídico del Sector Público], en el cual se desarrollan los preceptos constitucionales que regulan la potestad sancionadora de la Administración, incluye, en su artículo 127, este principio. ZORNOZA PÉREZ, J. J.: El sistema de infracciones ...op. cit., págs. 72 y 73; El principio de legalidad, aunque observado desde un punto de vista formal, se pone de manifiesto en el aforismo «nullum crimen, nulla poena sine lege». En función de este principio, ningún hecho puede ser considerado como delito sin que una Ley lo haya configurado como tal, ni ninguna pena podrá aplicarse si no ha sido previamente establecida por la Ley.24 La distinción entre principio de legalidad formal y material, supone responder a la pregunta de si ¿debe ser castigado como vulneración del ordenamiento, sólo lo previsto en la Ley o todo comportamiento socialmente dañoso? El artículo 25.1 de la CE indica que «nadie puede ser condenado o sancionado por acciones u omisiones que en el momento de producirse no constituyan delito, falta o infracción administrativa, según la legislación vigente en aquel momento». A la expresión «legislación vigente» utilizada por la Constitución, se le ha dado un diverso significado en el ámbito penal y administrativo... el término «Ley» es un término equívoco, pues puede tener diversas acepciones, así, puede ser utilizado para designar las normas surgidas de la «potestas normandi» del Estado, es decir, las normas de origen estatal decretadas

(C) UNED. Revista de Derecho UNED, núm. 26, 2020 
por la organización política constituida en forma de Estado, aunque, en un sentido más estricto, puede referirse a un determinado tipo de norma que ocupa un lugar preponderante entre las emanadas del Estado o de las CC AA, en este sentido "Ley» se opone a reglamento, Resulta generalmente admitido que la expresión «legislación vigente» del artículo 25.1 de la $\mathrm{CE}$, tendrá diverso significado al hacer referencia al ordenamiento Penal y al Administrativo. Si bien la identidad sustancial entre el ilícito penal y el administrativo, justifica su regulación unitaria en la Constitución, la intervención represiva que se produce en el ámbito penal tiene mayor intensidad que la producida en el ámbito administrativo, puesto que puede afectar a la libertad o a otros derechos fundamentales, es esta razón la que acredita el uso de elementos legislativos diversos, como la Ley orgánica o la ordinaria. En función de ello, y de la interpretación conjunta del artículo 25 de la CE con los artículos 9.3, 53.1 y 103 de la CE, consideramos que resulta aplicable en el ámbito sancionador administrativo el principio de legalidad, aunque manifestándose en este ámbito con menor intensidad... administrativo. La cuestión de la intensidad con que este principio deba ponerse de manifiesto en el ámbito sancionador administrativo, va a plantear diversas cuestiones, así, debe determinarse si es la Ley la que debe regular íntegramente las infracciones y sanciones administrativas, o si ésta podrá establecer principios y criterios en función de los cuales se determinen reglamentariamente; en el primer caso estaríamos ante una reserva absoluta, y en el segundo ante una relativa. La gran mayoría de la doctrina va a posicionarse a favor de la segunda de las opciones, aunque defendiendo la necesidad de que la Ley realice una descripción genérica de las conductas sancionables, sin que la remisión a normas reglamentarias suponga una deslegalización de la materia. Sobre este tema señala el TC que resulta necesario que la potestad sancionadora de la Administración se encuentre otorgada mediante norma con rango de Ley, no excluyendo esto la posibilidad de que las leyes contengan remisiones a normas reglamentarias, aunque será necesario que en las primeras se contengan los elementos esenciales de las conductas antijurídicas, la naturaleza y límites de las sanciones a imponer. El principio de legalidad prohibirá una remisión al Reglamento que haga posible una regulación independiente y no claramente subordinada a la Ley. PARADA distingue entre "el principio de "reserva absoluta de Ley" -que opera en materia penal-y de "cobertura legal" -aplicable a las sanciones administrativas-... en el primer caso, la ley legitimadora ha de cubrir por entero tanto la previsión de la penalidad como la descripción de la conducta ilícita (tipicidad) sin posibilidad de completar esa descripción por un reglamento de aplicación o desarrollo; mientras que el principio de "cobertura legal" de las sanciones administrativas sólo exige cubrir con ley formal una descripción genérica de las conductas sancionables y las clases y cuantía de las sanciones, pero con la posibilidad de remitir a la potestad reglamentaria la descripción pormenorizada de las conductas ilícitas, es decir, la tipicidad». CORDERO GARCÍA,J.A.:"La potestad sancionadora de la administración tributaria: principios reguladores”, $J T$, núm.5,2000, págs.1-7; Llegados a este punto, resulta significativa una polémica existente en la actualidad en Francia, donde los artículos 1729 y 1730 del CGI (Code Général des Impôts) establecen de una forma rígida la cuantía de las sanciones más usuales, ante esta situación parte de la doctrina y diversos planteamientos jurisprudenciales defienden la posibilidad de que las sanciones fijadas legalmente sean consideradas como límites máximos dentro de los cuales pueda imponerse una sanción más reducida. Consideramos que el respeto al principio de legalidad no puede suponer obviar otros como el de proporcionalidad de la sanción, pero la solución al problema francés no debe ser la atribución de una competencia discrecional a la Administración o a los órganos jurisdiccionales, al margen de lo previsto en la Ley. [ Vid. Corte Europea de Derechos del Hombre, Sentencias de 1 de diciembre de 1992 (caso Perrin), de 24 de febrero de 1994 (caso Bendenoun), de 29 de mayo de 1997 


\section{LA CONSUMACIÓN DEL PLAZO PRESCRIPTIVO DE LAS INFRACCIONES TRIBUTARIAS}

Teniendo presentes estas posibles combinaciones, preliminarmente esclareceremos en qué momento se consuman las distintas infracciones que se recogen en el articulado de la LGT ${ }^{12}$. No obstante, con carácter previo, se puede decir que las infracciones que producen perjuicio económico pueden ser leves, graves o muy graves, según el grado de culpabilidad ${ }^{13}$ en que incurra la conducta del presunto in-

(caso Malige), de 10 de febrero de 1983 (caso Lecomte), y de 23 de octubre de 1995 (Caso Schmautzer), entre otras. Consejo de Estado Francés, Sentencias de 5 de abril de 1996 (caso Houdmond), y de 4 de marzo de 1991, Corte de Casación Francesa, Sentencia de 29 de abril de 1997 (Caso Ferreira), Consejo Constitucional, Sentencia de 30 de diciembre de 1997. Tribunal Administrativo de Estrasburgo, Sentencia de 8 de diciembre de 1994 (caso Simon).]

12 La gran mayoría de los tipos infractores tributarios necesitan ser completados por las normas reguladoras de los tributos concretos, esta necesidad de integración afecta no sólo a la mayoría de las infracciones tributarias, sino a una gran parte de las correspondientes al Derecho Administrativo económico. Así, por ejemplo, para determinar cuándo se ha producido el disfrute indebido de una exención, o cuándo se ha acreditado improcedentemente una partida positiva o negativa en la base o en la cuota, será necesario acudir a la normativa de los tributos concretos, sin la cual resulta imposible calificar uno de estos supuestos como infracción. En función de todo ello, en el ámbito tributario nos encontramos con normas que establecen mandatos o unas prohibiciones concretas, y normas sancionadoras que incluyen conductas genéricas que engloban el incumplimiento de las prohibiciones o mandatos concretos. Como señala acertadamente RODRÍGUEZ BEREIJO, «el tipo de las infracciones tributarias difícilmente puede ser completo y consistir en una descripción directa de la conducta infractora, sino que surgirá, como regla, de la conjunción de dos normas, a saber: la que establece el mandato o prohibición y la que advierte que su incumplimiento es infracción, estableciendo la sanción correspondiente». RODRÍGUEZ BEREIJO, A.: "Derecho Penal Tributario y Derecho Sancionador en España", Revista Iberoamericana de Derecho Tributario, Derecho Penal y Sancionador Tributario (II), núm. 13, 1996, págs. 76 a 78; ZORNOZA PÉREZ,J.J.:El sistema de infracciones y sanciones tributarias. Los principios constitucionales del derecho sancionador, Civitas, Madrid,1992, págs. 87 y 88.

13 La prueba del acta de liquidación de haber dejado de ingresar las diferencias entre lo declarado en el IVA y los datos contables confirman la sanción en materia de IVA que se impone al recurrente. La prueba de la intencionalidad aunque fuese a título de simple negligencia ratifica la sanción tributaria (S TSJ Castilla y León, Burgos, Sala de lo Contencioso-Administrativo, Sec. 2. ${ }^{a}$, 1.3.2019). La inexistencia de bases negativas de ejercicios anteriores a compensar queda probado en el expediente administrativo que motiva la sanción, probándose la sanción del impuesto de sociedades por falta de ingreso de la deuda debida. La prueba de la simulación de las adquisiciones cuya deducibilidad se pretendía confirma el elemento subjetivo, el dolo y la voluntariedad en la elusión del pago del impuesto, merecedor de la sanción (S TSJ Castilla y León, Burgos, Sala de lo Contencioso-Administrativo, Sec. 2. $\left.{ }^{a}, 22.2 .2019\right)$. Basarse en el mero resultado obtenido en el procedimiento inspector es insuficiente para entender acreditado el elemento subjetivo de la culpabilidad cuando dice que no se puede sancionar por el mero resultado (TSJ Murcia, Sala de lo Contencioso-Administrativo, Sec. 2. $\left.{ }^{a}, 17.5 .2018\right)$. Para que exista sanción tributaria es requisito sine qua non la voluntad de querer ocultar o no declarar cualquier

(C) UNED. Revista de Derecho UNED, núm. 26, 2020 
fractor, y así, normalmente, son infracciones graves aquellas en las que se da la ocultación, existencia de facturas falsas ${ }^{14}$ o existencia de anomalías contables que no superen una determinada proporción, y muy graves aquellas en las que se produce la utilización de medios fraudulentos. Las conductas que no generen perjuicio económico, igualmente, se pueden calificar en leves, graves o muy graves, en función de la gravedad del comportamiento. De todos modos podemos distinguir dos grandes grupos de conductas sancionables, según la existencia o no de perjuicio económico para la Hacienda Pública. El primer grupo, englobaría las infracciones reguladas en los artículos 191 a 197 y 206 bis LGT, se puede identificar con las infracciones graves de la antigua Ley General Tributaria, y el segundo grupo ${ }^{15}$,

elemento sujeto a tributación por lo que no cabe el error de interpretación como elemento subjetivo del tipo. La sanción administrativa debe conllevar la intención del administrado de querer ocultar hechos imponibles así, el error de calificación en el tributo, no debe considerarse como elemento esencial de culpabilidad que integra la sanción tributaria (S TSJ Andalucía, Málaga, Sala de lo Contencioso-Administrativo, Sec. 2. $\left.{ }^{a}, 21.12 .2017\right)$. No procede la deducción de las facturas presentadas por empresas vinculadas porque no se acredita que éstas desarrollen ningún tipo de actividad. Procede la imposición de sanción porque está debidamente justificada en el hecho de que el recurrente dejó de pagar parte del IVA al deducirse gastos que no debía (STSJ Madrid, Sala de lo Contencioso-Administrativo, Sec. 5. ${ }^{a}, 14.12 .2017$ ).

14 Concurre el requisito de la culpabilidad en la actuación del interesado, porque se dedujo gastos que nos se corresponden con operaciones efectivamente realizadas por el emisor de la factura, amparándose en facturas que contienen datos falseados (STSJ Extremadura, Sala de lo Contencioso-Administrativo, Sec. 1. ${ }^{\text {a }}$, 28.4.2015).

15 Las infracciones formales presentan graves problemas de concepción y tipificación, en primer lugar, por el solapamiento del incumplimiento base, que denominamos instrumentalización de la tipificación, en segundo lugar, por la reiteración en la sanción de unas mismas conductas o instrumentalización de la infracción y, en tercer lugar, por el establecimiento de sanciones inadecuadas a su carácter formal o la instrumentalización de la sanción. $1^{\circ}$. Instrumentalización de la tipificación. En tal contexto existe el peligro de la identificación mimética entre incumplimiento e infracción, como si ambas realidades fueran una misma cosa. Con ello, se desconocerían los requisitos y exigencias propias de la infracción, y el papel del bien jurídico en tal contexto. Así, respecto de las obligación de presentar declaración, resulta que cualquier incumplimiento al mismo es infracción (art. 198 y art. 199 de la LGT), pues basta la mera inexactitud. Respecto de las obligaciones contables y registrales, las de facturación, o las relativas al uso del NIF, existe un pleno solapamiento entre incumplimiento de la obligación e infracción, ya que tales preceptos se remiten expresamente a la regulación de dicha obligación, coincidiendo incumplimiento e infracción. En los comportamientos de resistencia y negación a colaborar con la actuación de la Administración (art. 203 de la LGT), su configuración resulta próxima a las órdenes, y a posicionar al obligado como vinculado en una relación de especial de sujeción, más propia de un súbdito que de un ciudadano. También existe dicho solapamiento en las infracciones relativas a las obligaciones entre particulares resultantes del tributo, como el deber de sigilo, y las obligaciones de comunicar datos o entregar certificados en supuestos de retención (art. 204 a 206 de la LGT)... Tal estado de cosas aboca a que la descripción típica efectuada no es garantía de seguridad, no es propiamente 
que comprende las infracciones previstas en los artículos 198 a 206 LGT $^{16}$, encontraría su correspondencia con las denominadas infracciones simples de la antigua Ley General Tributaria.

La clasificación de las infracciones y sanciones tributarias recogida en el capítulo III del título IV de la LGT, que abarca los artículo 191 a 206 bis $^{17}$, ambos inclusive, recoge un buen número de conduc-

tipificación... $2^{\circ}$.Instrumentalidad de la infracción. Tal instrumentalización es llevada a cabo a través de la sanción reiterada de una misma obligación y de una misma conducta. Así, por un lado, se pune la reiteración de incumplimientos dentro de una misma obligación. O sea, la existencia de tantas infracciones como datos inexactos, falsos u omitidos de una misma obligación, aboca a una exacerbación punitiva de tales infracciones. De ahí resulta, que las infracciones basadas en obligaciones que coadyuvan al cumplimiento de la obligación principal, puedan ser sancionadas más gravemente que ésta, sin establecer, en muchas ocasiones, claros límites cuantitativos. Resulta un arduo problema dilucidar si a cada obligación le corresponde una sola infracción, o de si existen tantas como incumplimientos.. En definitiva, con tal sistema de sanciones se instituye una situación de sujeción que comporta una subordinación administrativa especial, impropia de la condición de ciudadano. No se ha de confundir colaboración con la Administración con una genérica y difusa obediencia y sumisión... $3^{\circ}$. Instrumentalidad de la sanción. En tercer lugar, aparece dicha instrumentalizad derivada del establecimiento de sanciones proporcionales para muchas de las infracciones formales. Con ello se evidencia una sanción inadecuada, ya que carece de relación a la conducta desvalorada... La sanción proporcional implica imponer un mal teniendo en cuenta el perjuicio de la conducta infractora. Dicha sanción no se corresponde con el comportamiento infractor, pues no se evalúa correctamente el mismo. Si la acción no comporta un resultado lesivo ¿cómo es posible establecer una sanción proporcional respecto del mismo? Con la sanción proporcional en las infracciones formales, que no causan perjuicio económico, se reprime lo que no se hace. Ha de existir una sanción acorde a la conducta objeto de reprensión. Tal situación favorece a la posición en el procedimiento de la Administración, pues no ha de probar perjuicio alguno. Dicha sanción configura a las infracciones formales como una figura hibrida y compleja. La complejidad e hibridez a que nos referimos deriva del hecho de que parece punirse un peligro abstracto para la obligación tributaria principal. De alguna manera, parece afirmarse que con tales infracciones, no solamente se vulnera una obligación formal, sino que se pone en peligro la deuda tributaria. Así, sin probar la existencia o derivación de dicho peligro para la deuda tributaria, de facto se sanciona como si existiera. Es una sanción discordante en relación a la conducta, vulnerando el principio de proporcionalidad y de culpabilidad...Por ello, si la infracción formal no conlleva resultado ni perjuicio evaluable, no procede imponer una sanción proporcional, sino fija. SÁNCHEZ HUETE, M.A.: "Elementos para un análisis del sistema de infracciones de la Ley General Tributaria”, CT, núm. 132, 2009,págs.191-194.

16 De este parecer son GARBERÍ LLOBREGAT, J.(Dir) et alii: El procedimiento administrativo sancionador, Tirant lo Blanch, Valencia, 1998, págs. 471 a 490; y MEMENTO PRÁCTICO FRANCIS LEFEVBRE. Inspección de Hacienda 2008-2009... op.cit. pág. 329.

17 De este modo, se viene a establecer un sistema de infracciones y sanciones enormemente complejo por la pretensión del legislador de describir, de forma casi matemática, la conducta concreta que se sanciona. Ello implica una cierta oscuridad de la norma para los ciudadanos y para los operadores jurídicos que, sólo 
tas infractoras del ordenamiento fiscal descritas individualmente, lo que trasluce desde un primer momento la sensación de que, en lugar de redactar los tipos hipotéticos de infracciones reconduciéndolos en lo posible y con el debido rigor al menor número de modalidades de infracciones, se ha optado por la descripción individualizada de todas las conductas que los autores del texto legal han considerado, sin el debido análisis que podrían constituir otras tantas situaciones infractoras, metodología que también se ha utilizado en la regulación establecida, entre otros, en los artículo 8 (materias reservadas), 29.2 (obligaciones tributarias formales), 35.2 (obligados tributarios), 92.3 (colaboración social en la aplicación de los tributos), 117.1 (actuaciones de gestión) e 141 (inspección).

Con esta metodología es imposible evitar el solapamiento en la descripción de algunas de las situaciones tipificadas separadamente, todo ello, además, en el ámbito de una Ley en la que no se recoge expresamente el principio non bis in idem.

La finalidad que persigue la vigente Ley General Tributaria es que la sanción sea menor en aquel contribuyente que simplemente ha defraudado a la Hacienda Pública, porque ha interpretado de manera incorrecta, pero no razonable, la norma, que en aquel otro, en el que están presentes la ocultación y/o los medios fraudulentos y/o cualquier otra circunstancia, que el legislador utiliza para calificar la infracción tributaria como grave o muy grave ${ }^{18}$. Por tanto, la calificación de las infracciones tributarias como graves o muy graves depende, respectivamente y en los principales tipos de infracción, de la existencia de ocultación de datos a la Administración Tributaria $\left(184.2^{\circ}\right.$ LGT) y de la utilización de medios fraudulentos $\left(184.3^{\circ}\right.$ LGT), siendo leve en aquellos casos en que no se den las anteriores circunstancias, así como en aquellos otros en que por razón de la cuantía descubierta la propia ley la califique de leve.

Como infracciones tributarias muy graves prevé la Ley General Tributaria las siguientes:

1. Las infracciones por dejar de ingresar toda o parte de la deuda; por incumplir la obligación de presentar declaraciones y documentos para liquidación administrativa, y por obtener indebi-

\footnotetext{
después de una minuciosa lectura alcanzan a comprender la conducta, los medios y el resultado que es preciso para que se cometa la infracción tributaria. ANEIROS PEREIRA,J.: Las sanciones tributarias, Marcial Pons, Madrid, 2005, pág.63.

18 RAMÓN DE LA POZA, L.M.: Procedimientos Tributarios. Infracciones y Sanciones, Ediciones Experiencia, Barcelona, 2005, pág. 35.
} 
damente devoluciones cuando se utilicen medios fraudulentos (apartado 4 de los artículos.191, 192 y 193 LGT)

2. La infracción por expedir facturas falsas o documentos sustitutivos con datos falsos o falseados (artículo 201.3 LGT).

3. La infracción por incumplir la obligación de proporcionar datos al pagador de rentas sometidas a retención o ingreso a cuenta, cuando se deriven de ello retenciones o ingresos a cuenta inferiores a los procedentes y el obligado tributario tenga obligación de presentar autoliquidación que incluya dichas rentas (artículo $205.3^{\circ}$ LGT).

Como infracciones tributarias graves se contemplan ${ }^{19}$ :

1. Las infracciones por dejar de ingresar toda o parte de la deuda, por incumplir ${ }^{20}$ la obligación de presentar ${ }^{21}$ declaraciones y documentos para liquidación administrativa, y por obtener indebidamente devoluciones, cuando se utilicen medios cuasi fraudulentos y cuando existiendo ocultación la base ${ }^{22}$ de la sanción supere los 3.000 euros (artículos 191,192 y 193 LGT).

2. La infracción por solicitar indebidamente devoluciones, beneficios o incentivos fiscales (artículo 194 LGT).

19 Siguiendo en esta relación a MARTÍN QUERALT,J.et alii: Derecho Tributario...op.cit.págs.222 a 224; Aunque también la exponen criticando que la previsión legal de una clasificación no comporta una obligación de la existencia de dicha clasificación en todas las infracciones. Tampoco resulta coherente ni proporcional en tanto que no establece la misma sanción para la misma calificación. SÁNCHEZ HUETE, M. A.: Las infracciones en la nueva Ley General Tributaria, Marcial Pons, Madrid,2007, pág. 129.

20 La ausencia de autoliquidación e ingreso en el plazo es constitutiva de infracción tributaria grave pero, por si misma, no conlleva agravación por ocultación (STS, Sala Tercera, de lo Contencioso-Administrativo, Sec. 2. , 27.10.2010).

21 No se presentó declaración, lo que no hubiera sido descubierto sin la correspondiente actuación inspectora, por lo que se aprecia culpabilidad de la conducta constitutiva de infracción grave (STS, Sala Tercera, de lo ContenciosoAdministrativo, Sec. 2. $\left.{ }^{\mathrm{a}}, 14.6 .2010\right)$.

22 No se aprecia desproporción entre la cuota exigida y la base de la sanción impuesta, siendo ésta la cantidad que la propia entidad reconoce que dejó de ingresar en su autoliquidación en concepto de retenciones. Cuando el art. 8.1 RD 2063/2004 (RGST) establece que la base de la sanción en la infracción prevista en el art. 191 Ley 58/2003 (LGT) será el importe de la regularización practicada, debe entenderse e interpretarse conforme a lo establecido en la norma legal a la que sirve de desarrollo, de manera que la base de la sanción será el importe de la regularización practicada en cuanto coincida con la cantidad no ingresada por el retenedor en la autoliquidación y que debiera haberlo sido(STSJ Galicia núm. 540/2016 de 2 de noviembre de 2016). 
3. La infracción por determinar o acreditar improcedentemente partidas positivas o negativas o créditos tributarios aparentes (artículo 195 LGT).

4. La infracción por imputar incorrectamente o no imputar bases imponibles, rentas o resultados por las entidades sometidas a un régimen de imputación de rentas (artículo 196 LGT).

5. La infracción por imputar incorrectamente deducciones, bonificaciones y pagos a cuenta por las entidades sometidas a un régimen de imputación de rentas (artículo 197 LGT).

6. La infracción por presentar de forma incompleta, inexacta o con datos falsos autoliquidaciones o declaraciones, así como los documentos relacionados con las obligaciones aduaneras ${ }^{23}$, siempre que no se haya producido o no se pueda producir perjuicio económico a la Hacienda Pública, o contestaciones a requerimientos individualizados de información (artículo 199 LGT).

7. La infracción por incumplimiento de las obligaciones tributarias y registrales (artículo 200 LGT).

8. La infracción por incumplir obligaciones de facturación, salvo el caso de expedición de facturas o documentos sustitutivos con datos falsos o falseados (artículo 201.1 LGT).

9. La infracción por incumplimiento de las obligaciones específicas de las entidades de crédito relativas a la utilización del número de identificación fiscal y de otros números o códigos establecidos por la normativa tributaria o aduanera (artículo 202.2 LGT).

10. La infracción por resistencia, obstrucción, excusa o negativa a las actuaciones de la Administración Tributaria (artículo 203 LGT).

11. La infracción por incumplimiento del deber de sigilo exigido a los retenedores y a los obligados a realizar ingresos a cuenta (artículo 204 LGT).

23 El párrafo segundo del art. 36.1 LGT, completa la definición del sujeto pasivo con una referencia al ámbito aduanero. Éste, como sabemos, es un terreno propio del sistema fiscal de la Unión Europea, regulado por el Código Aduanero Común (Reglamento 2913/1992, de 12 de octubre, del Consejo) [hoy regulado en el Reglamento 952/2013, de 9 de octubre, regulador del Código Aduanero de la Unión], donde se contiene una tipología de los deudores inspirada en principios singulares, no homologables con los empleados en las definiciones de la LGT. PÉREZ ROYO,F.: Derecho Financiero y Tributario. Parte General, Civitas, Madrid, 2009, pág.159. 
12. El incumplimiento de las obligaciones tributarias mediante la realización de actos o negocios cuya regularización se hubiese efectuado con ocasión de procedimiento de conflicto en aplicación de la norma tributaria y en la que hubiese resultado acreditada cualquiera de las situaciones previstas en los artículos 191, 193, 194 y 195 LGT (artículo 206 bis LGT)

Se consideran por la Ley como infracciones tributarias leves las siguientes:

1. Las infracciones por dejar de ingresar toda o parte de la deuda, por incumplir la obligación de presentar declaraciones y documentos para liquidación administrativa, y por obtener indebidamente devoluciones ${ }^{24}$, cuando no se utilicen medios fraudulentos ni cuasi fraudulentos y no se haya producido ocultación administrativa, y por obtener indebidamente devoluciones, cuando no se haya producido ocultación o la base de la sanción sea igual o inferior a 3.000 euros (artículos 191, 192 y 193 LGT).

2. Las infracciones por no presentar en plazo autoliquidaciones, declaraciones o documentos, cuando no exista perjuicio económico para la Hacienda Pública (artículo 198.1 LGT).

3. Las infracciones por incumplir la obligación de comunicar el domicilio fiscal de los no empresarios (artículo 198.5 LGT).

4. Las infracciones por incumplir las condiciones establecidas en las autorizaciones de autoridad aduanera o de las condiciones a que quedan sujetas las mercancías por aplicación de la normativa aduanera, cuando dicho incumplimiento no constituya otra infracción (artículo 198.6 LGT).

5. La infracción por incumplimiento de las obligaciones relativas a la correcta expedición o utilización de los documentos de circulación exigidos por la normativa de los Impuestos Especiales, salvo que constituya infracción tipificada en la ley reguladora de dichos Impuestos (artículo 201.4 LGT).

6. La infracción por incumplimiento de las obligaciones relativas a la utilización del número de identificación fiscal y de otros números o códigos establecidos por la normativa tributaria o

24 La infracción tributaria por la obtención indebida de devoluciones tiene el carácter de leve porque la base de la sanción no supera $3.000 €$, por lo que se impone el 50\% de la cantidad dejada de ingresar (STSJ Andalucía, Granada, Sala de lo Contencioso-Administrativo, Sec. 1. ${ }^{\mathrm{a}}, 26.9 .2011$ ). 
aduanera, salvo que se trate de deberes específicos de entidades de crédito (artículo 202 LGT).

7. La infracción por incumplir la obligación de proporcionar datos al pagador de rentas sometidas a retención o ingreso a cuenta, cuando se deriven de ello retenciones o ingresos a cuenta inferiores a los procedentes y el obligado tributario deba de presentar autoliquidación que incluya dichas rentas (artículo 205 LGT).

8. La infracción por incumplir la obligación de entregar el certificado de retenciones o ingresos a cuenta (artículo 206 LGT)

Así pues, dado que el bien jurídico protegido a través de la tipificación de las infracciones tributarias es la recaudación de los ingresos, las infracciones que tratan de proteger la efectiva lesión del mismo, esto es, la defraudación tributaria, se pueden denominar infracciones de lesión mientras que los tipos infractores que pretenden evitar que este bien se ponga en peligro, pueden recibir, lógicamente esta calificación. Además, la conducta puede llevarse a cabo realizando una acción que está prohibida por el ordenamiento o no realizando la que la ley exige. Por último, puede ser suficiente la acción u omisión ${ }^{25}$, sin que sea preciso obtener un resultado -son las infracciones de mera actividad cuando hay acción o las de omisión propia cuando no la hay, esto es, se castiga sólo un no hacer, con independencia del resultado-, o se puede requerir que éste se consiga -denominadas infracciones de resultado en los casos en los que hay acción o infracciones de omisión impropia, cuando no es suficiente con el no hacer sino que a su vez ha de producirse un resultado ${ }^{26}$.

En el vigente sistema, los criterios que van a determinar la mayor o menor gravedad de la infracción son el perjuicio económico causado, el riesgo de la conducta y la mayor o menor intencionalidad del autor reflejada en la naturaleza de los medios utilizados para vulnerar la ley.

25 MARTÍN QUERALT,J.; LOZANO SERRANO,C.; POVEDA BLANCO,F.: Derecho Tributario, Aranzadi, Navarra,2008, pág.222.

26 FERREIRO siguiendo a Mir Puig, clasifica las infracciones de resultado (arts. 191 a 193 y 201 LGT) y las de mera actividad (el resto de infracciones de la LGT). A su vez distingue si el tipo requiere lesión o basta su puesta en peligro, y los de esta última naturaleza los subdivide en infracciones de peligro concreto-que requiere una efectiva situación de peligro-, y los de peligro abstracto- que no requieren que en el caso concreto la acción cree un peligro efectivo-... FERREIRO LAPATZA, J.J.: Curso de Derecho Financiero Español: Instituciones, Marcial Pons, Madrid,2006, pág. 560. 


\section{LA PRESCRIPCIÓN DE LA INFRACCIÓN TRIBUTARIA CONSISTENTE EN DEJAR DE INGRESAR LA DEUDA TRIBUTARIA}

\subsection{Supuesto de hecho de la prescripción de la infracción tributaria consistente en dejar de ingresar la deuda tributaria ${ }^{27}$, como infracción que causa o puede causar perjuicio económico ${ }^{28}$}

27 La ocultación inherente a este tipo infractor, así como al de los arts. 192 y 193 de la LGT, resulta elemento subjetivo inherente a la descripción típica de estas infracciones por lo que en ningún caso puede volverse a desvalorar como circunstancia cualificante, no podrá ser objeto de una doble sanción, de una parte como elemento intrínseco y de otra como circunstancia específica de dichos preceptos que sirva para agravarlos. La ocultación no entraña una controversia sobre aspectos jurídicos, sobre una calificación jurídica, sino sobre una situación fáctica derivada de la conducta del imputado. SÁNCHEZ HUETE,M.A.: Las infracciones...op.cit.págs.154 y 155; La ocultación no puede depender de la conducta de la Administración Tributaria (STS de 4 de marzo de 2003); La Administración puede conocer cuando regulariza a través de los datos ya declarados por el contribuyente. (STS de 2 de junio de 2001, STSJ Castilla-León de 22 de febrero de 1993, y RTEAC de 20 de julio de 1994); SsTSJ de Madrid de 9 y 16 de julio de 2009 (FJ7 ${ }^{\circ}$ y FJ5, respectivamente; STSJ de Madrid de 19 de noviembre de $2009\left(\mathrm{FJ}^{\circ}\right)$ y STS de 15 de enero de 2009.

28 Algún autor efectúa la división de infracciones de la LGT en aquellas que causan perjuicio económico (arts. 191 a 194), las que preparan el perjuicio económico(arts. 195 a 197), y las infracciones de deberes relacionados con la aplicación de los tributos (arts. 198 a 206). MARTÍNEZ LAGO, M.A. y GARCÍA DE LA MORA, L.: Lecciones de Derecho Financiero y Tributario, Iustel, Madrid, 2009, págs. 531 a 555; Sin embargo seguiremos la tradicional distinción entre infracciones sustanciales y formales, establecida en base a la existencia de un perjuicio económico que existe en las primeras y no en las segundas; En igual sentido MESTRE GARCÍA, E. y CERVANTES SÁNCHEZ-RODRIGO, C. J.: Guía de infracciones y sanciones tributarias, CISS, Valencia, 2005, pág. 120; Aunque ZORNOZA critica este criterio porque entre las infracciones que consideramos con perjuicio económico se cuentan algunos tipos sancionadores en los que dicho perjuicio no existe, al menos de forma directa, por referirse a comportamientos que, como máximo, tienen carácter preparatorio de otras acciones y omisiones que serán, la que , en caso de realizarse, originen el perjuicio. ZORNOZA PÉREZ,J.J.: El sistema...op.cit. pág. 226; Distinguiendo entre infracciones materiales (arts. 191 a 197 LGT) y formales (arts. 198 a 206) encontramos a SÁNCHEZ HUETE,M.A.: Las infracciones...op.cit.pág. 133; también a PÉREZ ROYO,F.: Infracciones y Sanciones Tributarias, IEF, Madrid,1972, págs. 99 a 101; Distinguiendo entre infracciones de contenido pecuniario y formal. SÁNCHEZ HUETE, M.A.: "Una visión crítica del sistema sancionador de la LGT", JT,2006,BIB 2006\327; cabe distinguir entre las infracciones basadas en incumplimientos de la obligación tributaria principal, de las que se basan en los incumplimientos de obligaciones sin contenido pecuniario o formal. Dentro de las primeras, cabe diferenciar, a su vez, entre las conductas que causan perjuicio a la Hacienda Pública -si derivadas de autoliquidación (art. 191), si de una declaración (art. 192) o relativas a obtener devolución (art. 193)-; y las conductas que preparan dicho perjuicio, cuya sanción se impone en la medida que implica un peligro para la obligación principal -en 
La comisión de esta infracción se produce en caso de falta de ingreso $^{29}$ de la totalidad o parte de la deuda tributaria ${ }^{30}$ que debería re-

caso de solicitar devoluciones (art. 194), determinar o acreditar partidas (art. 195), imputación incorrecta en el régimen de imputación de rentas (art. 196 y art. 197)-. Dentro de las infracciones formales, basadas en el incumplimiento de obligaciones que no tienen un contenido pecuniario y que, en ningún caso, generan perjuicio económico directamente evaluable, se tipifican las relativas a la presentación de declaraciones o autoliquidaciones (art. 199 y art. 198), al deber de contabilidad (art. 200), al deber de facturación (art. 201), a los deberes del NIF (art. 202), las que refieren a la resistencia, obstrucción, excusa o negativa (art. 203), y las basadas en obligaciones formales relativas al mecanismo de la retención -deber de sigilo, comunicación y certificación (arts. 204, 205 y 206)-. SÁNCHEZ HUETE,M.A.: "Una visión crítica...op.cit."; Con otro criterio, PÉREZ ROYO, más correcta le parece la opción de distinguir y clasificar los tipos en función del deber infringido. Todas las infracciones tributarias consisten en la violación de alguno de los deberes impuestos por la Ley a los obligados tributarios...Violación de deberes, todos ellos, de carácter formal, aunque en algunos casos los más significativos, se exige también que, como consecuencia de esa violación de deberes formales, se haya producido también un resultado de daño para la recaudación tributaria. Nuestra propuesta es clasificar las infracciones en función de la naturaleza del deber infringido. PÉREZ ROYO,F.: Derecho Financiero....,op.cit.,2009,págs.398-399; AA.VV. (Coord. PELÁEZ MARTOS, J. Ma ${ }^{\mathrm{a}}$ ): Todo procedimiento Tributario 2007-2008, CISS, Valencia,2007, págs. 318-330, se recogen los diferentes modelos de declaraciones, autoliquidaciones y comunicaciones, y su normativa -en el ámbito de la AEAT-.

29 La ausencia de acreditación por la Administración de la falta de ingreso en plazo de la deuda tributaria que debiera resultar de la correcta autoliquidación, conlleva la retirada de la sanción (STSJ Andalucía, Sevilla, Sala de lo ContenciosoAdministrativo, Sec. 3. $\left.{ }^{\mathrm{a}}, 18.12 .2008\right)$.

30 No todo el contenido de la deuda tributaria que explicita el art. 58 de la LGT, es sancionado, sino sólo el contenido principal del art. 58.1, y o el del art. 58.2. SÁNCHEZ HUETE,M.A.: Las infracciones...op.cit., pág. 148; También respecto de la LGT de 1963, PÉREZ ROYO,F.: Los delitos y las infracciones en materia tributaria, IEF, Madrid,1986, pág. 325; Según la STSJ Región de Murcia de 23 de noviembre de 2009, la obligación de realizar pagos fraccionados tiene carácter autónomo respecto de la obligación principal, y por tanto, el sujeto sancionado estaba obligado a realizar los pagos fraccionados, con independencia de que, al realizar la declaración anual del ejercicio, resultase una cuota a devolver. Considera que al haberse realizado sobre el importe total de la cuota del pago fraccionado que se dejó de ingresar, se ha obtenido un resultado desproporcionado. Entiende que la Administración ha de tener en cuenta el resultado final de la liquidación del ejercicio y tomar, como base para el cálculo de la sanción, únicamente el perjuicio efectivo que le ha supuesto la falta de realización de los pagos fraccionados, que se concreta en la pérdida del anticipo de liquidez que suponen dichos pagos a cuenta. ZOZAYA MIGUÉLIZ,E.: "Sólo cabe sancionar por el daño realmente causado", Aranzadi Doctrinal, núm. 5,2010; Conforme a la Ley 35/2006 IRPF: Artículo 39. Ganancias patrimoniales no justificadas. Tendrán la consideración de ganancias de patrimonio no justificadas los bienes o derechos cuya tenencia, declaración o adquisición no se corresponda con la renta o patrimonio declarados por el contribuyente, así como la inclusión de deudas inexistentes en cualquier declaración por este impuesto o por el Impuesto sobre el Patrimonio, o su registro en los libros o registros oficiales. Las ganancias patrimoniales no justificadas se integrarán en la base liquidable general del período impositivo respecto del que se descubran, salvo que el contribuyente pruebe 
suficientemente que ha sido titular de los bienes o derechos correspondientes desde una fecha anterior a la del período de prescripción; Comentando dicho precepto MARTÍN LÓPEZ expresa que "Conclusiones. La STC 87/2001 declara, de un modo concluyente a lo largo de la misma, que la figura de los «incrementos no justificados de patrimonio» contenida en el artículo 20 párrafo $13^{\circ}$ de la Ley 44/1978, de 8 de septiembre, según la redacción dada por la Ley 48/1985, de 27 de diciembre, constituye renta a los efectos del Impuesto sobre la Renta de las Personas Físicas, negando, por tanto, que dichos incrementos sean una presunción «iuris tantum» de renta establecida «ex lege». Afirmación que tiene como principal consecuencia admitir la posibilidad de sancionar penalmente la defraudación de cuotas tributarias que se deriven de la apreciación de incrementos no justificados de patrimonio, sin que con ello se lesione el derecho a la presunción de inocencia o el principio de legalidad penal. Pero el carácter concluyente con que el Alto Tribunal realiza tal aserto no parece igualmente predicarse del razonamiento empleado para sustentarlo. En efecto, la idoneidad de la argumentación utilizada por la Sentencia para calificar los incrementos no justificados de patrimonio como una modalidad más de renta ha sido, cuanto menos, puesta en no pocas dudas al analizar en el apartado precedente los Fundamentos Jurídicos de la Sentencia. Dudas que hemos puesto de manifiesto desde una triple perspectiva: primero, por la imposibilidad de considerar los incrementos no justificados de patrimonio como una clase o especie de incremento patrimonial, lo que ha quedado suficientemente acreditado tras el análisis de uno y otro concepto; segundo, por la distinta naturaleza que los incrementos no justificados de patrimonio poseen con respecto al resto de elementos integrantes de la renta, lo que también ha quedado demostrado después de examinar el concepto de renta gravable acogido por la Ley; tercero, por la discutible concepción de la estructura de la norma efectuada por el Tribunal, al integrar dentro del supuesto de hecho la posibilidad de prueba en contrario, es decir, la actividad probatoria.... Más acorde con la norma hubiera sido admitir el carácter presuntivo de dicho instituto para, a pesar de no poder imponer una sanción con base en ella debido a las exigencias que derivan del derecho constitucional a la presunción de inocencia, acudir posteriormente al régimen de la prueba indiciaria en orden a posibilitar el castigo penal del mencionado fraude fiscal."MARTÍN LÓPEZ,J.: "Incrementos no justificados de Patrimonio y Delito Fiscal", Jurisprudencia Tributaria Aranzadi, núm. 2,2002 (Estudio), Pamplona, 2002, BIB 2002\521,pág.15; Según SIMÓN ACOSTA, al tratar los incrementos no justificados de renta observa que «el problema de fondo es si la adquisición onerosa o el patrimonio oculto están dentro del concepto de renta adoptado por el legislador. Ciertamente no hay un concepto de renta externo o anterior a la Ley. Es la Ley la que puede ordenar que la adquisición onerosa o el patrimonio oculto sean renta. Pero resulta que la Ley española no lo ordena, pues no delimita el hecho imponible en función del destino que se da a la renta (consumo más variación de patrimonio, donde estarían como un elemento más los patrimonios ocultados) sino en su origen o fuente: son renta todas las afluencias de riqueza al patrimonio. Por tanto el patrimonio no encaja dentro del concepto legal de renta, sino que es simplemente uno de los posibles destinos que pueden darse a la renta. los incrementos no justificados de patrimonio no son renta tal y como ésta es concebida por la ley, lo que ocurre es que el concepto legal de renta, que se refiere a la renta en su origen o fuente, es enormemente amplio e incluye casi todas las afluencias de riqueza. Por tanto, es perfectamente coherente con el concepto legal de renta el establecimiento de una presunción mediante la cual el patrimonio ocultado se convierte en renta salvo que se pruebe que no lo es». SIMÓN ACOSTA, E.: "Los incrementos no justificados de patrimonio", Cuadernos de Jurisprudencia Tributaria, Aranzadi, 1997, pág. 48; la STS de 16 de marzo de 2002 anula una sanción señalando

(c) UNED. Revista de Derecho UNED, núm. 26, 2020 


\section{sultar de una correcta ${ }^{31}$ autoliquidación ${ }^{32}$ del tributo dentro de los}

que no se puede sancionar por el mero «incumplimiento de obligaciones tributarias». No resulta admisible, pues, una sanción por el mero resultado. Además, la decisión de sancionar «debe estar soportada no por juicios de valor ni afirmaciones generalizadas, sino por datos de hecho suficientemente expresivos y detallados, con descripción individualizada, incluso, de las operaciones que puedan entenderse acreedoras de sanción»... la STC 164/2005, de 20 de junio... llegó a la conclusión de que la imposición de una sanción vulneró el derecho de los recurrentes a la presunción de inocencia al señalar que se vulnera el derecho a la presunción de inocencia cuando "se impone la sanción por el mero hecho de no ingresar, pero sin acreditar la existencia de un minimo de culpabilidad y de ánimo defraudatorio, extremo del que en la resolución judicial viene a prescindirse», y que «no se puede por el mero resultado y mediante razonamientos apodícticos sancionar, siendo imprescindible una motivación específica en torno a la culpabilidad o negligencia y las pruebas de las que ésta se infiere». ANEIROS PEREIRA, J.: "El elemento subjetivo de las infracciones tributarias y sus consecuencias en la aplicación del Derecho Sancionador", Quincena Fiscal, Aranzadi núm. 21, 2011, BIB 2011\1751, pág.7; Por otra parte, también habrá que atender a la existencia de normas internacionales, especialmente a los convenios de doble imposición, pues, si existieran, la aplicación del IRNR dependerá de que el convenio atribuya competencia para gravar las rentas concretas que sean objeto de exención al Estado de la fuente, ya sea de forma exclusiva o compartida con el Estado de residencia. SERRANO ANTÓN,F.: Fiscalidad Internacional, CEF, Madrid, 2006, pág.47. Se cuestiona que la BASE DE CÁLCULO de la sanción en el IRPF debe reducirse en el importe de las cuotas que resultaron a devolver en la misma regularización, por lo que hace a la sociedad interpuesta. No es posible tal interpretación, a la luz del art. 191 de la LGT, que tipifica la infracción y cuantifica la sanción sin contemplar tal posibilidad. Se reitera criterio fijado en resolución de 5/06/2014, RG.3478/2013 (RTEAC 7.5.2015).

31 Comentando el ejercicio de opciones que según la normativa tributaria se deban ejercitar, solicitar o renunciar, con la presentación de una declaración (autoliquidación o comunicación de datos) la LGT señala que no podrán rectificarse con posterioridad a ese momento, salvo que la rectificación se presente dentro del período reglamentario de la declaración (STSJ Cataluña 15.06.2001, RTEAC 0.03.1995). Por primera vez con este precepto se prohíbe la rectificación de opciones válidamente ejercitadas en el momento de presentar la correspondiente declaración. Cuestión distinta es que no se haya ejercitado la correspondiente opción, dentro del plazo previsto para ello, y posteriormente se pretenda el ejercicio de dicha opción mediante la declaración presentada fuera de plazo. El cálculo de la deuda tributaria mediante un sistema de tributación más desfavorable para el interesado debe considerarse un error que puede fundamental la solicitud de rectificación de la autoliquidación (STSJ CCAA Valenciana 26.03.2004). La renuncia extemporánea al régimen de estimación objetiva del IRPF o al régimen simplificado del IVA produce plenos efectos, con independencia de la posible infracción por la presentación del modelo 036 fuera de plazo (RTEAC 13.02.2004). AA.VV. (Coord. PELÁEZ MARTOS, J.M ${ }^{\mathrm{a}}$.): Todo procedimiento...op.cit. pág.420; La sanción por falta de ingreso en una autoliquidación exige que ésta sea manifiestamente errónea o temeraria (STS 27.09.1999); No puede sancionarse la falta de ingreso por considerar como no deducibles determinados gastos al no poderse considerar la declaración como manifiestamente errónea o inexistente (STSJ Andalucía 30.10.2003, STSJ Murcia 14.03.2001). Ibíd...op.cit.pág.1000.

32 La expresión legal no puede llevar a afirmar que la actuación administrativa posterior de comprobación que corrige lo declarado por el contribuyente se retrotraiga e integre el contenido de dejar de ingresar. No puede ser sancionada la 
plazos $^{33}$ establecidos ${ }^{34}$. Por ende, el plazo de prescripción se iniciará a partir del día siguiente ${ }^{35}$ al que finalice el plazo para autoliquidar la

falta de ingreso de una deuda tributaria inexistente en el momento de producirse. SAN de 26 de febrero de 2004; Al igual que la infracción que antes contemplaba el art. 79.a) LGT 1963, tenemos como elemento caracterizador el de referirse sólo a tributos en los que opere el procedimiento de autoliquidación. Véanse por ejemplo la SsTSJ La Rioja de 14 de febrero de 2000 y de Castilla y León de 7 de marzo de 2000.El tipo infractor no alcanza a las faltas de ingreso amparadas por la presentación, dentro de plazo, de una declaración-liquidación que, aunque pueda resultar incorrecta, sea completa por reflejar todos los datos requeridos tal y como aparezcan en una contabilidad regular (STS de 27 de septiembre de 1999, STSJ Cataluña de 22 de junio de 2000). AA.VV. (Dir. HERRERA MOLINA,P.M.): Factbook Fiscal, IEF, Thomson-Aranzadi, Navarra, 2004, pág. 291.

${ }_{33}$ La sanción resulta procedente cuando no se acredite que el estado de salud de su padre le impidiera dedicar tiempo al cumplimiento de la obligación de ingresar la deuda tributaria ni tampoco un erróneo asesoramiento recibido (S TSJ Castilla y León, Valladolid, Sala de lo Contencioso-Administrativo, Sec. 1. $\left.{ }^{a}, 13.7 .2015\right)$; Se confirma la sanción por retrasar sistemáticamente la mayor parte del ingreso del IVA devengado al cuarto trimestre, al no justificar que las administraciones a las que prestaba servicio haya sido en ese momento y no otro (SAN, Sala de lo Contencioso-Administrativo, Sec. 6. ${ }^{\mathrm{a}}, 23.6 .2015$ ).

34 PÉREZ ROYO,F.: Los delitos...op.cit. pág. 321; PÉREZ ROYO, F. y AGUAllo AVILÉS, A.: Comentarios a la Reforma de la Ley General Tributaria, Aranzadi, Navarra, 1996, pág. 246; es «la hipótesis más clásica de la infracción tributaria», FERNÁNDEZ CUEVAS, A.: "Las infracciones tributarias" en la obra colectiva Comentarios a las Leyes tributarias y financieras, Tomo I, Edersa, Madrid, 1985, pág. 107; es la «infracción reina», PONT CLEMENTE, J.F.: "Delimitación de las infracciones graves consistentes en la falta de ingresos tributarios repercutidos o de cantidades retenidas o que hubieran debido retenerse a cuenta de cualquier impuesto (art. 88.3 LGT)”, Revista Técnica Tributaria, núm. 29, 1995, pág. 70.

35 DÍEZ OCHOA opina se entenderá cometida esta infracción el último día del plazo de presentación. DÍEZ OCHOA, J.M.: Derecho Tributario...op.cit. pág. 247; En el ámbito penal, la doctrina mayoritaria -en materia de IVA- sostiene que la regla del art. 305.2 CP tiene una doble función. Por un lado, sería una regla de acumulación en los casos en los que las diversas liquidaciones periódicas no alcanzaran a defraudar la cuantía típica, en cuyo caso, si se alcanzara la referida cuantía sumándose todas las liquidaciones periódicas realizadas a lo largo del año natural, habría delito. Por otro lado, sería una regla que impide la valoración autónoma de lo defraudado en cada período, debiendo esperarse hasta el final del año. Ello se pretende sostener incluso por razones específicas del IVA. Así se indica que, dada la deducibilidad del IVA soportado, podría ser que la cantidad defraudada en dos o tres trimestres superara la cuantía típica y, en cambio, a final del año aquella cantidad acabara quedando por debajo de la frontera de la tipicidad- esto mismo acontecería con el Impuesto de Sociedades (IS)-. La consecuencia principal del planteamiento dominante es que el delito se consumaría el día treinta de enero del año natural siguiente al considerado, fecha que determinaría el punto de inicio para el cómputo de la prescripción. Y que incluso en el caso de que lo defraudado en cada uno de los períodos por separado superase la cuantía típica no podría apreciarse un delito continuado, sino un solo delito único (SAP Madrid Secc. 6ª de 20 de septiembre de 2002). SILVA SÁNCHEZ,

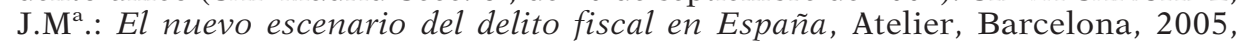
págs.103-108.

() UNED. Revista de Derecho UNED, núm. 26, 2020 
deuda ${ }^{36}$. Esta infracción, que puede denominarse como «omisión de ingresos tributarios» ${ }^{37}$, es la más común e importante de las infracciones tributarias ya que va a producir un resultado que afecta negativamente a la recaudación tributaria. Es un supuesto de infracción por omisión impropia, ya que se ordena a evitar un resultado lesivo, no siendo suficiente el no hacer o no $\operatorname{presentar}^{38}$ la autoliquidación, sino que exige la falta de ingreso ${ }^{39}$.

Siguiendo el comentario al precepto 191 LGT, al señalar el mencionado artículo que la falta de ingreso ${ }^{40}$ se ha de producir dentro de los plazos reglamentarios, se está refiriendo a la presentación de declaraciones que conllevan una liquidación-impropia-, es decir, los su-

36 Hubiese sido más correcto iniciar la cuenta del plazo desde el momento del nacimiento de la obligación, desde la perspectiva del Derecho de Obligaciones. Es cierto que la Administración no puede actuar hasta pasado el plazo de pago voluntario, pero también lo es que dispone de información muy frecuente que permite un seguimiento temporal cuasi continuo de los distintos hechos y elementos que pueden dar lugar a la generación de la obligación tributaria. CALVO ORTEGA,R.: Curso de Derecho Financiero. Derecho Tributario. Parte General, Civitas, Madrid,2010, pág. 243.

37 La conducta típica se realizará con los datos que se declaran o con la cuantificación del tributo que efectúe el sujeto en la autoliquidación pero nunca por la falta de recaudación de las cantidades derivadas de una autoliquidación presentada. ANEIROS PEREIRA,J.: Las sanciones...op.cit. pág. 73; ZORNOZA PÉREZ,J.J.: "De la omisión de ingresos tributarios a las infracciones de omisión. Comentario a la Resolución del TEAC de 20-11-1990", CT, núm. 64, 1992, pág. 141.

38 STS núm. 364/2019, de 18 de marzo de 2019. FJ TERCERO.- Criterios interpretativos sobre el artículo 37.2 LIRPF/1998 . 1) De la literalidad del artículo 37.2, párrafo segundo, LIRPF/1998, se desprende que para imputar las aportaciones efectuadas a una cuenta corriente a un concreto periodo impositivo lo determinante es el momento en el que la Administración descubre las ganancias patrimoniales no justificadas, debiéndose imputar en la base liquidable general del período impositivo en el que afloran. 2) Para que las ganancias patrimoniales no justificadas no se integren en la base liquidable general del período impositivo en que se descubran, basta, conforme al artículo 37.2, párrafo segundo, LIRPF/1998 , con probar que se es titular o propietario de los bienes o derechos -en este caso, del dinero aportado en las cuentas- desde una fecha anterior a la del período de prescripción, sin que sea preciso además identificar la fuente u origen de la que proceden tales bienes o derechos.

39 BLASCO DELGADO,C.: La prescripción de las infracciones y las sanciones, Civitas, Madrid, 2003, pág.123; No se puede sancionar por dejar de ingresar la cuota de IVA de una factura y por no haberla emitido (STSJ Cataluña 27.01.1999).

40 "Lo que hace ver, como con todo acierto señala Pérez Royo, que nos hallamos ante una infracción de resultado. Lo que se castiga no es sólo la falta de ingreso (dejar de ingresar en la equívoca terminología de la Ley), sino el incumplimiento de la obligación de autoliquidar que produce o posibilita el resultado cierto y efectivo de la falta de ingreso en los plazos queridos por la Ley .Falta de autoliquidación completa y veraz y falta real y efectiva del ingreso son los dos elementos esenciales que configuran el núcleo de la acción que..se tipifica....”. FERREIRO LAPATZA, J.J.: Curso de Derecho .... Instituciones, ...op.cit., pág. 557. 
puestos de autoliquidación, y no así a los supuestos en los no se presenta la declaración para que la Administración pueda liquidar, pues esta último caso se recoge en el art. 192 LGT, y como se verá, hace referencia a otro supuesto diferente al ahora analizado.

Lo que caracteriza a esta infracción es la falta de ingreso en plazo ${ }^{41}$, pero debemos preguntarnos cuándo se entiende que se ha ingresado en plazo, para lo que resulta esclarecedora la STS de 2 de abril de 1996, en la que siendo la discrepancia la determinación de cuál es la fecha de ingreso, o bien el día en que se ingresa en la entidad colaboradora, o bien el día en que esta última abona el importe de la deuda tributaria en la cuenta dispuesta al efecto por Administración, concluimos con el Tribunal Supremo que a la vista de lo establecido por los arts. 78 LGT 1963 (actual 191 LGT 2003) y 80.7 RGR 1990 (actual $34.4^{\circ} \mathrm{RGR}$ ) la fecha de ingreso del sujeto pasivo es aquélla en la que ingresa en la entidad colaboradora, independientemente de que se haya abonado inmediatamente en la cuenta abierta por la Administración acreedora.

Respecto de la culpabilidad ${ }^{42}$, en general, « la apreciación de la culpabilidad en la conducta del sujeto infractor es una exigencia que surge directamente de los principios constitucionales de la seguridad jurídica y de legalidad en cuanto al ejercicio de potestades sancionadoras de cualquier naturaleza. El principio de culpabilidad constituye un elemento básico a la hora de calificar la conducta de una persona como sancionable, es decir, es un elemento esencial en todo ilícito administrativo, y es un principio que opera no sólo a

41 Sancionar por la falta de ingreso de la cuota derivada de incrementos no justificados de patrimonio puede ser contrario al principio de presunción de inocencia, habida cuenta de que la citada cuota tributaria resulta de una presunción legal de obtención de renta y no de una renta cuya existencia haya sido probada ( Resolución del TEAC de 23 de febrero de 2001).SIMÓN ACOSTA,E.: "Incrementos no justificados de patrimonio y sanciones tributarias", $J T, 2001$, BIB 2001\960; Por el contrario, justificando la imposición de sanciones y exponiendo las diferentes teorías al respecto, GRAU RUÍZ,M.A.: "La posibilidad de sancionar los incrementos no justificados de patrimonio", $Q F$,núm.19,1995.

42 Si con anterioridad a la fecha de una liquidación practicada por la Administración, el contribuyente había compensado el IVA pendiente de acuerdo con sus cálculos, y estos son considerados posteriormente como improcedentes por razón de unos hechos que se califican en el expediente de regularización como no constitutivos de infracción tributaria, porque se entiende acreditado que el contribuyente actuó con la diligencia debida, no procede la apreciación de negligencia en los períodos posteriores que queden afectados por la regularización, porque son los hechos regularizados en el período de origen (calificados como no negligentes) los que han motivado la improcedente cuantificación del saldo a compensar en los períodos posteriores y las consecuentes erróneas autoliquidaciones (RTEAC, Vocalía 5. ${ }^{\mathrm{a}}$, 26.4.2011). 
la hora de analizar la conducta determinante de la infracción, sino también sobre las circunstancias agravantes.

Las alegaciones en cuanto a la interpretación razonable de la norma que puedan esgrimirse, deben ser puestas en relación con el examen de que se ha cumplido en ese caso la necesaria motivación del acuerdo sancionador, sin perjuicio que también lo pueda ser la resolución o liquidación del correspondiente procedimiento de aplicación de los tributos del que pueda traer causa el sancionador ${ }^{43}$.

El Tribunal Supremo es especialmente exigente en esta materia, pudiendo citarse la sentencia de 15 de enero de 2009 que expresa: «...como señalamos en el fundamento de derecho Sexto de la Sentencia de 6 de junio de 2008 (rec. cas. para la unificación de doctrina núm. 146/2004), «es evidente que en aquellos casos en los que, como el presente, la Administración tributaria no motiva mínimamente los hechos o circunstancias de los que deduce que el obligado tributario ha actuado culpablemente, confirmar la sanción porque este último no ha explicitado en qué interpretación alternativa y razonable ha fundado su comportamiento, equivale, simple y llanamente, a invertir la carga de la prueba, soslayando, de este modo, las exigencias del principio de presunción de inocencia, en virtud del cual, «la carga de la prueba corresponda a quien acusa, sin que nadie esté obligado a probar su propia inocencia» [ SSTC 76/1990, de 26 de abril , FJ B); 14/1997, de 28 de enero, FJ 5 ; 169/1998, de 21 de julio, FJ 2 ; 237/2002, de 9 de diciembre, FJ 3 ; y 129/2003, de 30 de junio,

43 Si se dispone de los datos o pruebas necesarios para la fijación en el procedimiento sancionador de los elementos determinantes de la infracción y la sanción, resulta posible la aplicación del régimen sancionador tributario a los incumplimientos de obligaciones tributarias materiales sin necesidad de tramitar previamente un procedimiento de aplicación de los tributos destinado a comprobar esas obligaciones materiales. Tales datos o pruebas habrán de haberse obtenido en todo caso en el seno de un previo procedimiento de aplicación de los tributos que, sin estar destinado necesariamente a la comprobación de obligaciones tributarias materiales, sea adecuado a su finalidad. En el caso concreto que da lugar al criterio, se trata de un supuesto en el que el obligado tributario presenta, previo requerimiento de la Administración -requerimiento éste formulado en el seno de un procedimiento de control de la obligación formal de presentar declaraciones/autoliquidaciones-, autoliquidaciones complementarias, incluyendo rentas procedentes de cuentas en Suiza que no habían sido declaradas en plazo, siendo sancionado por la Administración por la infracción tipificada en el artículo 191 de la LGT. El previo procedimiento de comprobación del cumplimiento de la obligación de presentar declaraciones, que finaliza con la regularización del propio obligado tributario con la presentación de las autoliquidaciones complementarias, se estima idóneo para el inicio del ulterior procedimiento sancionador por la infracción tipificada en el art. 191 de la LGT por dejar de ingresar el importe que hubiera debido resultar de la correcta autoliquidación del tributo (RTEAC 3.7.2014). 
FJ 8], de manera que «no es el interesado quien ha de probar la falta de culpabilidad, sino que ha de ser la Administración sancionadora la que demuestre la ausencia de diligencia» [ Sentencia de 5 de noviembre de 1998 (rec. cas. núm. 4971/1992 ), FD Segundo].

En efecto, como se destaca en la STS de 10 de julio de 2007 (rec. cas. para la unificación de doctrina núm. 306/2002 ) que «en el enjuiciamiento de las infracciones es al órgano sancionadora quien corresponde acreditar la concurrencia de los elementos constitutivos de la infracción, en este caso de la culpabilidad», de manera que "no es la recurrente quien ha de acreditar la razonabilidad de su posición, sino que es el órgano sancionador quien debe expresar las motivaciones por las cuales la tesis del infractor es «claramente» rechazable» (FJ Segundo).

Y es que sólo cuando la Administración ha razonado, en términos precisos y suficientes, en qué extremos basa la existencia de culpabilidad, procede exigir al acusado que pruebe la existencia de una causa excluyente de la responsabilidad, como es el caso de la que establecía el art. 77.4.d) LGT («cuando el contribuyente haya presentado una declaración veraz y completa y haya practicado, en su caso, la correspondiente autoliquidación, amparándose en una interpretación razonable de la norma»), que, con otras palabras pero con idéntico alcance, se recoge ahora en el art. 179.2 d) de la Ley 58/2003 ( «cuando el obligado haya actuado amparándose en una interpretación razonable de la norma») [SsTS núm. 690/2017, de 20 de abril de 2017, FJ 4ं STS 723/2017, de 27 de abril de 2017, FJ 4ª].

Por tanto, no resultará válido el argumento esgrimido sobre la debida diligencia que se ha puesto en el cumplimiento de sus obligaciones tributarias, cuando las declaraciones presentadas, a juicio del órgano jurisdiccional, no sean en absoluto veraces, pues la valoración que debe dar el obligado tributario a la operación u hecho realizado ha de resultarle de aplicación unos criterios medianamente rigurosos.

Asimismo, cabe señalar que efectivamente en aquellos casos en los que el obligado tributario se ampara en una interpretación razonable de la norma, aunque esta resulte errónea, se excluye la responsabilidad por falta del elemento subjetivo de la infracción, de acuerdo tanto por lo establecido en el artículo 179.2.d) de la Ley 58/2003, de 17 de diciembre, General Tributaria, como en una constante jurisprudencia. El Tribunal Supremo ha manifestado que para excluir la responsabilidad las interpretaciones discrepantes deben ser razonables y razonadas. Así, por ejemplo, la STS de 20 de noviembre de 
1991 determinó que «... Sin embargo, sin desconocer la doctrina jurisprudencial que, ante una diferencia razonable de criterio respecto de la interpretación de normas tributarias, admite que esta dificultad puede ser causa excluyente de culpabilidad, en el campo de la potestad sancionadora de la Hacienda Pública, hay que convenir en que la aplicación de este criterio no debe extenderse hasta llegar a acoger cualquier duda que se suscita en orden al sentido y alcance de una normativa tan señaladamente susceptible de controversia, pues de otro modo quedaría sin contenido la más común de las infracciones fiscales, deducida de la falta de declaración del hecho imponible». Y la STS de 19 de diciembre de 1997 declara que: "[a]unque es cierto que una consolidada doctrina jurisprudencial excluye la existencia de infracción tributaria, y por lo tanto la procedencia de sanción, de aquellos supuestos en que se produzca una discrepancia sobre las normas jurídicas a considerar -en su alcance, contenido o aplicación al caso controvertido- de suerte que llegue a demostrarse que no hay ánimo de ocultar o evitar a la Administración el conocimiento del hecho imponible del tributo cuestionado, en más cierto que, para que tal doctrina resulte viable y aplicable es necesario que la discrepancia interpretativa o aplicativa pueda calificarse de razonable, es decir, que esté respaldada, aunque sea en grado mínimo, por fundamento objetivo. En caso contrario, o sea, de no exigirse ese contenido mínimo de razonabilidad o fundamentación, en todo supuesto de infracción, bastaría la aportación de cualquier tipo de alegación contraria a la sostenida por la Administración para que conductas objetivamente sancionables resultaran impunes. No basta pues que exista una discrepancia jurídica; es preciso, además, que la misma tenga el grado necesario de razonabilidad».

Por ende la invocación de estas causas no opera de modo automático como excluyentes de la culpabilidad sino que han de ser ponderadas caso por caso, en función de las circunstancias concurrentes, de tal modo que excluyan la calificación de la conducta como negligente, ya sea por la existencia de una laguna legal, ya por no quedar clara la interpretación de la norma o porque la misma revista tal complejidad que el error haya de reputarse invencible.

Novedosamente, se incluye en el tipo de infracción la falta de ingreso por los socios, herederos, comuneros o partícipes de las entidades en régimen de atribución de rentas, de las cantidades no atribuidas o atribuidas incorrectamente ${ }^{44}$, sin perjuicio de la sanción

44 En el régimen de atribución las rentas son obtenidas directamente por los socios, comuneros o partícipes y ellos son los responsables de su correcta declaración. En cambio, en el régimen de imputación d rentas, las rentas son obtenidas por la entidad, que es la que tiene la obligación de declararlas e 
que, en su caso, pudiera corresponder a la propia comunidad o entidad obligada a atribuir rentas por las infracciones que hubiera cometido ${ }^{45}$. Así en el caso de una comunidad de bienes, dicha entidad

imputarlas a los socios o partícipes y la que incurre en una conducta infractora en caso de no hacerlo; La nueva LGT no introduce cambio alguno sobre la anterior, sino que aclara el alcance de la obligación de acuerdo con la entidad en régimen de atribución de rentas-donde los socios obtienen la renta- de que trata el párrafo. MESTRE GARCÍA, E. y CERVANTES SÁNCHEZ-RODRIGO, C. J.: Guía de infracciones...op.cit. pág.122; Efectivamente, tal y como ha sido señalado por la Dirección General de Tributos, el régimen de entidades en atribución de rentas implica que las rentas correspondientes a sociedades civiles, tengan o no personalidad jurídica, herencias yacentes, comunidades de bienes y demás entidades que, carentes de personalidad jurídica, constituyen una unidad económica o un patrimonio separado, se atribuirán a los socios, herederos, comuneros y partícipes, según las normas aplicables y si no constasen a la Administración, se atribuirán por partes iguales. ES decir, que se prescinde de la entidad, siendo los miembros de la misma quienes deben integrar en su declaración por el IRPF, por el IS o por el IRNR las rentas obtenidas a través de la misma, de tal forma que la entidad en atribución se configura como una agrupación de contribuyentes a quienes se atribuyen las rentas generadas por la misma (Resoluciones de 10 de junio y 10 de julio de 1997); El problema es que para que el comportamiento de los socios, herederos...resulte sancionable, será necesario apreciar, al menos, negligencia, lo no cual no siempre va a ser sencillo dado que su conducta estará provocada por la ausencia de información de la misma por la entidad (ex art. 69.2. RD 1775/2004 [actual art. 70.2 del Real Decreto 439/2007, de 30 de marzo, por el que se aprueba el Reglamento del Impuesto sobre la Renta de las Personas Físicas y se modifica el Reglamento de Planes y Fondos de Pensiones, aprobado por Real Decreto 304/2004, de 20 de febrero]), de modo que, cuando dicha culpabilidad no pueda ser probada, aquello, por las cantidades dejadas de ingresar no van a recibir ningún tipo de sanción, pero al mismo tiempo el comportamiento de la entidad que, actuando de forma dolosa o negligente, no realice o realice de forma incorrecta la atribución de cantidades a sus miembros puede quedar en algunos casos impune, al no encontrar acomodo en ninguno de los tipo de infracción previstos en la LGT. Se advierte que el art. 90 de la Ley 35/2006 exime de la obligación informativa de rentas a atribuir cuando no ejerzan actividades económicas y sus rentas no excedan de 3.000 euros anuales. ANÍBARRO PÉREZ, S y SESMA SÁNCHEZ,B.: Infracciones y sanciones tributarias, Lex Nova, Valladolid,2005, págs. 114 y 115; En efecto, si bien en el art. 195 de la LGT podrían encuadrarse algunos de los incumplimientos descritos, no sucede así con la falta total de atribución por parte de la entidad a sus miembros, ni tampoco varias de las hipótesis de incorrecta atribución de cantidades a los mismos. RODRÍGUEZ MÁRQUEZ,J.:"La colaboración de terceras personas en las infracciones tributarias: el caso particular de las entidades en régimen de atribución de rentas", JT, núm.4,2003, pág. 27.

45 La conducta negligente o culposa ha de darse en la propia entidad obligada a atribuir rentas (por arts. 196, 197 y 198.1 LGT), de tal forma que si en ésta no se apreciase..... será difícil apreciar la comisión de una infracción en los socios, herederos, comuneros o partícipes. DÍEZ OCHOA, J.M.: Derecho Tributario...op.cit. pág. 265. Este mismo autor observa que en los supuestos de falta de ingreso que deriva de los rendimientos, deducciones, bonificaciones y pagos a cuenta no imputados o imputados incorrectamente, sigue siendo de aplicación el criterio de entender que existe un único sujeto infractor, la entidad que no imputa o imputa 


\section{puede ser sujeto infractor por conductas relacionadas con obligacio-}

incorrectamente, no siendo sancionable en el socio de la misma la falta de ingreso que derive de las rentas, deducciones, bonificaciones y pagos a cuenta no imputados o imputados incorrectamente; Advierte SIMÓN ACOSTA que «se puede producir aquí un concurso de infracciones con el tipo previsto por el art. 195 de la LGT (determinar o acreditar improcedentemente partidas positivas o negativas o créditos tributarios aparentes) pues la comunidad o entidad sin personalidad jurídica que atribuye la renta a sus partícipes es sujeto activo de esta otra infracción. La infracción de determinar partidas improcedentemente es medio necesario para cometer la de la falta de ingreso por los partícipes y el desvalor de la conducta está contemplado por la infracción de dejar de ingresar». A su juicio, además, se trata del mismo sujeto infractor. "Tipología de las infracciones tributarias en la LGT», La nueva Ley General Tributaria, Civitas, 2004, pág. 756; Siendo esto así, la conclusión que obtenemos es que, en la mayor parte de las ocasiones, el partícipe de la entidad que no elabora su declaración, por carecer de la información, o la confecciona con los datos erróneos suministrados por la entidad del art. 33 de la LGT no padecerá consecuencia sancionadora alguna, por falta de culpabilidad. Sobre todo, le resultará muy difícil a la Administración demostrar la existencia de dicha culpabilidad,... La conclusión anterior se refuerza si tenemos en cuenta los últimos pronunciamientos judiciales, que refuerzan la aplicación del principio de culpabilidad en la aplicación del art. 79.a) de la LGT. A título de ejemplo, pero muy expresivo de lo que queremos decir, la STS de 27 de septiembre de 1999. 4 afirma que «el tipo de infracción grave del apartado a) del art. 79, antes y después de la precitada reforma introducida por la Ley 25/1995, de 20 de julio, en un régimen de autoliquidación preceptiva, requería y requiere que se haya producido una falta de ingreso derivada de una declaración-liquidación manifiestamente errónea y hasta cabría decir que temerariamente producida». RODRÍGUEZ MÁRQUEZ,J.:"La colaboración ...”,op.cit..JT, núm.4,2003; La atribución de rentas es un concepto acuñado en la normativa del IRPF e Impuesto de Sociedades y referido a los casos de rentas o resultados, en general, obtenidos por sociedades civiles y entes sin personalidad jurídica, como las comunidades de bienes y herencias yacentes. Este tipo de entidades, aunque realicen una actividad económica, no son sujeto pasivo del IRPF ni del IS: las rentas y resultados se obtienen y atribuyen a los socios o partícipes, que deben integrarla en su propia base imponible y tributar en el IRPF o IS, según que se trate de personas físicas o jurídicas....ahora bien, aunque la entidad no es sujeto pasivo, los resultados de su actividad se determinan inicialmente de forma unitaria, en cabeza de la propia entidad, la cual debe, a continuación, atribuirlos a los socios o partícipes sobre la base de las cuotas que a cada uno correspondan. En un régimen de este tipo, caben al legislador dos opciones, en cuanto a la tipificación de las infracciones. Cabría sancionar como infracción la ocultación de los beneficios por la entidad, pues la posterior conducta de los partícipes es simplemente una consecuencia casi necesaria de la tributación que hace la entidad. Sería un sistema similar al que se emplea respecto de las entidades en régimen de imputación de rentas...La opción alternativa, es la de sancionar la infracción en la conducta de cada socio, por la comisión del tipo general de dejar de ingresar total o parcialmente la cantidad correspondiente a las rentas o bases imponibles no atribuidas o atribuidas de manera incorrecta. Esta segunda fue la opción que eligió la LGT anterior, y también...ha elegido la nueva. PÉREZ ROYO,F.: Derecho Financiero ... 2009,pág.402; ...debemos llegar a la conclusión que el incumplimiento de la obligación impuesta por el art. 74.bis.3de la LIRPF (1998) puede dar lugar a responsabilidad por infracción de la propia entidad. Ahora bien, para que ello sea posible es necesario que la conducta se encuentre tipificada como tal infracción, ya 


\section{nes formales, o por la falta de ingreso de impuestos en los que sea}

sea grave o leve. Infracciones graves. Comenzando con las infracciones graves, debe diferenciarse entre los tipos de incumplimiento que pueden producirse por parte de la entidad. De un lado, la omisión absoluta de la comunicación y, de otro, su emisión con falsedades, omisiones o inexactitudes. La omisión de la notificación. En cuanto al primero, parece que tenemos que desechar su posible subsunción en alguno de los tipos de infracción grave regulados en la LGT. En primer lugar, puede pensarse en incluir esta conducta en los tipos regulados en las letras a), b) y c) del art. 79 de la LGT (1963). Sin embargo, según la interpretación usual de los mismos, sólo se refieren, como sujeto activo, al propio obligado tributario que acaba omitiendo el ingreso. Por tanto, desde un punto de vista práctico y aunque no compartamos su fundamento, no puede entenderse que la entidad en régimen de atribución realice el tipo descrito en dichas normas. A nuestro juicio, la posición anterior no es la correcta. Esta cuestión se enmarca, en realidad, en la problemática acerca de la posibilidad de que un tercero, distinto del obligado, pueda ser autor de un ilícito tributario. En efecto, respecto de la obligación del partícipe, la entidad, en principio, constituye un tercero, ya que no es la persona que debe realizar la prestación debida a favor de la Hacienda Pública. Por tanto, debemos preguntarnos si, en el estado actual de nuestra legislación, es posible sancionar a un tercero que defrauda la cuota tributaria del obligado. Dicha posibilidad resulta controvertida, habiéndose suscitado las mayores dudas en relación con el delito fiscal. En efecto, la doctrina discrepa acerca de la naturaleza de dicho delito, discutiéndose si es especial o común... Trasladando este problema al ámbito de las infracciones administrativas -y centrándonos en el tipo más importante, es decir, en el regulado en las letras a) y b) del art. 79 de la LGT (1963) -, hemos de preguntarnos si éstas sólo pueden ser cometidas por el obligado principal, o se admite la participación, en concepto de autor, de terceras personas, ajenas a la relación tributaria. Ya hemos señalado en trabajos anteriores que, a nuestro juicio, debe ser considerado «sujeto infractor»-según la terminología empleada por la LGT- de la infracción tipificada en las letras a), b) y c) del art. 79 de la LGT (1963) cualquier persona que realice la conducta consistente en dejar de presentar o en falsear las declaraciones o autoliquidaciones, siempre que ello dé lugar a un perjuicio económico para la Hacienda Pública. El falseamiento de declaraciones y autoliquidaciones sí puede ser ejecutado por el deudor y un tercero de forma conjunta o, incluso, sólo por este último. De esta forma, entendemos que pueden ser sujetos infractores todas aquellas personas que, según los conceptos empleados en Derecho Penal, deban ser calificados como autores o coautores... En el caso que nos ocupa, ¿̇realiza la acción típica la entidad que omite la certificación o sólo colabora a su ejecución? Dejando de lado las importantes discusiones doctrinales que se han suscitado sobre esta materia en el ámbito penal, la jurisprudencia de nuestro Tribunal Supremo tampoco resulta muy clara. Así, durante mucho tiempo ha mantenido (Entre otras, pueden citarse las SsTS de 22 de febrero de 1985, de 13 de mayo de 1986 y de 5 de julio de 1990) la tesis del acuerdo de voluntades, que supone que siempre que exista un concierto entre dos o más personas para llevar a efecto la realización de un plan delictivo trazado por ellos, dicho acuerdo establece un vínculo de solidaridad penal que les hace partícipes con igual grado de responsabilidad, cualquiera que sea la función o contenido que a cada uno de los concertados se les asigne. Con arreglo a dicha tesis, desde luego, puede considerarse que la entidad que se concierta con sus partícipes para omitir la comunicación, provocando así que éstos no puedan elaborar su declaración del impuesto, debe considerarse coautor. Pero es más, la tesis del acuerdo de voluntades está siendo objeto de revisión por parte del propio Tribunal Supremo. Así, en sus últimas resoluciones entiende que dicho acuerdo es condición necesaria pero no suficiente para que pueda hablarse de coautoría, de 
sujeto pasivo, como en el IVA. Pero no será sujeto infractor por la renta no declarada de la entidad, ya que corresponde hacerlo a sus socios y, por tanto, ellos son los sujetos infractores mencionados en el art. 191 de la LGT $^{46}$.

El tipo absorbe la falta de presentación o presentación incorrecta de autoliquidaciones ${ }^{47}$.

manera que a aquél debe sumarse el dominio funcional del hecho (STS de 7 de octubre de 2002), dicho dominio «se manifiesta en el papel que le corresponde en la división del trabajo, integrado en la decisión conjunta del hecho». Por tanto, existe coautoría «cuando a la decisión común acompaña una división de papeles o tareas que no importe subordinación de unos respecto de otro o de otros y ese aporte principal exterioriza el dominio funcional de cada uno sobre el hecho que se va a realizar». Por tanto, ya no bastaría con la existencia de un acuerdo entre la entidad y sus miembros, sino que cada uno de ellos debe tener el dominio del hecho en el sentido expuesto, lo que dificulta más la apreciación de un supuesto de coautoría. Otra posibilidad de sancionar estas conductas a través de los tipos que venimos examinando pasa por obviar la posible existencia de un concierto y la culpabilidad del partícipe -dada la dificultad de acreditar estos extremos-, centrándonos en el comportamiento de la entidad. De esta forma, nos encontraríamos ante un supuesto de autoría mediata de la entidad, en la que el partícipe sería un mero instrumento. Ello, salvo que se pueda apreciar negligencia en su comportamiento, en cuyo caso sí sería un autor inmediato. Es decir, la entidad sería calificada como «autor tras el autor». No obstante, no se nos escapa que, si ya es difícil que la práctica administrativa y judicial admitan la existencia de supuestos de coautoría en las infracciones tributarias, la apreciación de una autoría mediata es poco menos que una quimera.La conclusión que se obtiene de todo ello es que, como indicábamos al principio, resulta muy difícil castigar a la entidad mediante la aplicación de las letras a), b) o c) del art. 79 de la LGT (1963)... la emisión de la notificación pero con falsedades, omisiones o inexactitudes, el examen de la tipicidad de la conducta exige dos tipos de análisis previos. De un lado, es preciso conocer el contenido exacto de la notificación que están obligadas a cursar las entidades a sus partícipes. De otro lado, se requiere un estudio de cada uno de los tipos en que pudiera tener encaje. Comenzando por la primera... pueden identificarse tres tipos de alteraciones en la comunicación que pueden provocar una falta de ingreso en la declaración del partícipe. En primer lugar, la omisión o el falseamiento de los ingresos a imputar. En segundo lugar, la certificación de bases de deducciones superiores a las procedentes. Por último, la comunicación de obligaciones a cuenta satisfechas superiores a las reales. RODRÍGUEZ MÁRQUEZ,J.: "La colaboración... ",op.cit.págs.4-6.

46 AA.VV. (Coord. PELÁEZ MARTOS, J.Mª): Todo procedimiento...op.cit. pág. 1070.

47 MESTRE GARCÍA, E. y CERVANTES SÁNCHEZ-RODRIGO, C. J.: Guía de infracciones...op.cit. págs.121 y 122.; No presentar declaración hace presumir que existe una voluntad del sujeto de evasión, de dejar de pagar. Asimismo, no se cuestiona el legislador si la Administración conoce o puede conocer el contenido de aquello que tenía que declarar el obligado. Pues si conoce, no existe la lesión del bien jurídico que ampara dicha infracción. Se ha de partir de la base que la sanción es el último medio que posee el ordenamiento para restaurar el orden quebrantado. SÁNCHEZ HUETE,M.A.; “Una visión crítica..."op.cit., JT, BIB 2006\327; para que la Administración tributaria pueda sancionar por... los tipos que hacen hoy referencia a declaraciones inexactas o incorrectas -siempre, e importa resaltarlo, 


\subsection{Naturaleza del tipo infractor}

Observamos, como hace Pérez Royo ${ }^{48}$, al tratar la infracción del deber de declarar el presupuesto de hecho de la deuda tributaria con resultado de daño para la recaudación (arts. 191, 192 y 193 LGT), que el primero deberes formales de los obligados al pago de deudas tributarias es el poner en comunicación de la Administración el hecho imponible (en caso de la obligación principal) o el presupuesto de hecho de las obligaciones de pago a cuenta (pagos fraccionados, retenciones e ingresos a cuenta de pagos en especie). Adveramos que esta declaración es imprescindible para que la Administración pueda practicar la liquidación, en el caso de los tributos que se exigen mediante este procedimiento ${ }^{49}$, o, en todo caso, para que la Adminis-

en supuestos de autoliquidación impuesta al sujeto pasivo- es lógico exigir que la declaración-liquidación sea tan manifiesta e injustificadamente errónea como para calificarla de inexistente. FALCÓN Y TELLA,R.: "La motivación de las sanciones y la STS 10 julio 2007: la necesidad de que el órgano administrativo justifique el carácter irrazonable de la conducta del contribuyente", $Q F$, núm. 7, 2008; la Administración tributaria no puede eludir, a la hora de practicar una valoración de una transferencia de bienes entre entidades vinculadas, los actos previos de cálculo que haya podido realizar cuando éstos hacen referencia a los mismos bienes, y ello con independencia de que se realicen en el marco de uno u otro tributo, pues en estos supuestos debe prevalecer el principio constitucional de seguridad jurídica con respecto a la libre disponibilidad de la Inspección de elegir el método de verificación indiciario contemplado en la Ley (STS de 30 de noviembre de 2009). CÁNCIO FERNÁNDEZ,R.C.: "Valoración de ventas entre sociedades vinculadas: La libre elección del método indiciario no puede socavar el principio de seguridad jurídica", $Q F$, núm.12,2010; En relación con la falta de ingresos de pagos a cuenta, la SAN 15.02.2001, estando vigente la Ley 230/1963, consideró que no efectuar los pagos a cuenta del I. Sociedades, estando obligado a ello, con independencia de que en un momento posterior y una vez efectuada la autoliquidación del ejercicio resultara a devolver todo o parte de lo ingresado en concepto de dicho pago a cuenta, se considera que la conducta es constitutiva de infracción grave, sin que la liquidación anual ulteriormente presentada comporte la aplicación del art. 61 LGT, en aplicación de lo dispuesto en el art. 79 LGT. AA.VV. (Coord. PELÁEZ MARTOS, J.M ${ }^{\mathrm{a}}$.): Todo procedimiento..op.cit.pág.1071.

48 PÉREZ ROYO,F.: Derecho Financiero ...,op.cit.,2009, págs.400-401.

49 A este respecto debe destacarse que la generación de la deuda aduanera derivada de las operaciones de importación resulta de un proceso complejo que comienza con la introducción de la mercancía en el territorio aduanero y la presentación de la declaración sumaria, continúa con la presentación de la declaración aduanera y el subsiguiente reconocimiento y aforo, y culmina con la liquidación y pago de los derechos y la expedición del levante, que permite al interesado disponer de la mercancía importada. La relevancia de todos los elementos que configuran este proceso complejo la pone de manifiesto el Código Aduanero cuando señala: - artículo 37 (hoy art. 134 del Reglamento (UE) $\mathrm{n}^{\circ}$ 952/2013 del Parlamento Europeo y del Consejo, de 9 de octubre de 2013, por el que se establece el código aduanero de la Unión -CAU-]) "1. Las mercancías introducidas en el territorio aduanero de la Comunidad estarán bajo vigilancia aduanera desde su introducción. Podrán ser sometidas a controles por parte 
tración pueda comprobar el correcto cumplimiento de sus obligaciones por el sujeto pasivo, en los casos en que el ingreso se realiza mediante autoliquidación. En resumen, estamos ante una infracción de resultado o de daño para la recaudación tributaria, pero que se produce mediante la violación o incumplimiento del deber de declarar. Tanto en el supuesto de hecho del artículo 191 como en el artículo 192, la infracción se cometerá (o empezará a cometerse) con la violación del deber de declarar ${ }^{50}$. Esto debe ser advertido especialmente

de las autoridades aduaneras, de conformidad con las disposiciones vigentes. 2. Permanecerán bajo vigilancia aduanera todo el tiempo que sea necesario para determinar su estatuto aduanero y en lo que se refiere a mercancías no comunitarias y sin perjuicio de lo dispuesto en el apartado 1 del artículo 82, hasta que o bien cambien de estatuto aduanero, o bien pasen a una zona franca o depósito franco o bien se reexporten o destruyan, de conformidad con el artículo 182". - artículo 202.1 (hoy art. 79.1 CAU): "Dará origen a una deuda aduanera de importación: a) la introducción irregular en el territorio aduanero de la Comunidad de una mercancía sujeta a derechos de importación". A los efectos del presente artículo, se entenderá por introducción irregular: "Cualquier introducción que viole las disposiciones de los artículos 38 a 41". - artículo 50: "Hasta tanto reciban un destino aduanero, las mercancías presentadas en aduana tendrán, desde el momento de su presentación, el estatuto de mercancías en depósito temporal". - artículo 204.1.a): "Dará origen a una deuda aduanera de importación el incumplimiento de cualquiera de las obligaciones a que quede sujeta una mercancía sometida a derechos de importación como consecuencia de su estancia en depósito temporal". De todo lo anterior debe deducirse el carácter de declaración tributaria de la declaración sumaria y, en consecuencia, el incumplimiento o el cumplimiento incorrecto de las obligaciones relativas a su presentación podría constituir una infracción tributaria simple, en los términos previstos en el artículo 78 de la Ley General Tributaria (consulta 0698-03 de la SG de Impuestos Especiales y de Tributos sobre el Comercio Exterior).

50 En cualquier caso el acuerdo sancionador ha de expresar adecuadamente los elementos objeto y subjetivo que conforman la infracción cometida, de tal forma que la simple afirmación de "dejar de ingresar la deuda tributaria" a modo de motivación no es admisible en un estado de derecho. En ese sentido la STSJ Castilla-León (Valladolid) núm. 1485/2015, de uno de julio de dos mil quince, sentenció "FJ CUARTO.- Sobre la infracción del principio de culpabilidad. Literalmente, el acuerdo sancionador refiere lo siguiente « MOTIVACIÓN Y OTRAS CONSIDERACIONES Dejar de ingresar deuda Art. 191 L.G.T. «. En relación con la aplicación al ámbito sancionador de los principios y garantías del derecho penal, el Tribunal Constitucional ( STC 76/1990, 120/1994, 154/1994, 23/1995, 97/1995, 147/1995 y 45/1997 ) ha establecido como uno de los pilares básicos para la interpretación del Derecho Administrativo sancionador que los principios y garantías básicas presentes en el ámbito del derecho penal son aplicables, con ciertos matices, en el ejercicio de cualquier potestad sancionadora de la Administración Pública. Más concretamente, respecto del exigible elemento subjetivo de la culpabilidad objeto de controversia, con carácter general ha de señalarse la STS de 23 octubre 2009 establece que la mera constatación de que procedía la regularización del ejercicio por haberse deducido indebidamente determinados gastos, no permite fundar la imposición de sanciones tributarias, dado que éstas no "pueden ser el resultado, poco menos que obligado, de cualquier incumplimiento de las obligaciones tributarias a cargo de los contribuyentes", no 
en el caso de las autoliquidaciones, en las que la infracción del de-

pudiendo fundarse la existencia de infracción en la mera referencia al resultado de la regularización practicada por la Administración tributaria porque no es posible sancionar por la mera referencia al resultado. Así lo ha puesto de manifiesto también, en términos que no dejan lugar a dudas, el Tribunal Constitucional en la STC 164/2005, al señalar que se vulnera el derecho a la presunción de inocencia cuando « impone la sanción por el mero hecho de no ingresar, pero sin acreditar la existencia de un mínimo de culpabilidad y de ánimo defraudatorio, extremo del que en la resolución judicial viene a prescindirse ", y que " no se puede por el mero resultado y mediante razonamientos apodícticos sancionar, siendo imprescindible una motivación específica en torno a la culpabilidad o negligencia y las pruebas de las que ésta se infiere ". A este respecto, la STS de 15 de septiembre de 2011 dictada en el recurso 3334/2007 resume su doctrina señalando que " la no concurrencia de alguno de los supuestos del art. 77.4 de la LGT "no es suficiente para fundamentar la sanción " porque "el principio de presunción de inocencia garantizado en el art. 24.2 CE no permite que la Administración tributaria razone la existencia de culpabilidad por exclusión o, dicho de manera más precisa, mediante la afirmación de que la actuación del obligado tributario es culpable porque no se aprecia la existencia de una discrepancia interpretativa razonable -como ha sucedido en el caso enjuiciado o la concurrencia de cualquiera de las otras causas excluyentes de la responsabilidad de las recogidas en el art. 77.4 LGT (actual art. 179.2 Ley 58/2003 ), entre otras razones, porque dicho precepto no agota todas las hipótesis posibles de ausencia de culpabilidad. A este respecto, conviene recordar que el art. 77.4.d) LGT establecía que la interpretación razonable de la norma era, «en particular» [el vigente art. 179.2.d) Ley 58/2003, dice «[entre otros supuestos»], uno de los casos en los que la Administración debía entender necesariamente que el obligado tributario había "puesto la diligencia necesaria en el cumplimiento de las obligaciones y deberes tributarios"; de donde se infiere que la circunstancia de que la norma incumplida sea clara o que la interpretación mantenida de la misma no se entienda razonable no permite imponer automáticamente una sanción tributaria porque es posible que, no obstante, el contribuyente haya actuado diligentemente" [...Sentencia 25 de febrero de 2010 (rec. cas. núm. 2166/2006 ); y de 31 de marzo de 2011 (rec. cas. núm. 290/2008 )]. Es evidente, por tanto, que la Sentencia de la Audiencia Nacional impugnada viene a confirmar la sanción impuesta por la Administración tributaria sin especificar, con el suficiente grado de detalle que la imposición de una medida punitiva merece, de qué concretos comportamientos se infiere que la sociedad recurrente actuó culpablemente. En fin, como acabamos de señalar, ninguno de los argumentos empleados por la Sentencia de la Audiencia Nacional recurrida en casación resultan útiles para fundar la existencia de culpabilidad. Pero, aunque hubiera ofrecido otros idóneos para fundar la concurrencia de simple negligencia, tampoco ello podría conducir a la confirmación de la sanción, dado que los órganos de la jurisdicción contenciosoadministrativa no pueden subsanar los defectos de motivación cometidos por el órgano competente para imponer las sanciones administrativas. En particular, como venimos recordando desde la Sentencia de 6 de junio de 2008, "en la medida en que la competencia para imponer las sanciones tributarias previstas en la LGT corresponde exclusivamente a la Administración tributaria, es evidente que los déficit de motivación de las resoluciones sancionadoras no pueden ser suplidos por los órganos de la jurisdicción ordinaria que, en este ámbito, sólo pueden llevar a cabo un mero control de la legalidad. En este sentido se ha pronunciado también el Tribunal Constitucional que, con fundamento en que no son los Tribunales Contencioso- Administrativos, sino la Administración Pública quien, en uso de sus prerrogativas constitucionales, sanciona a los administrados, ha señalado que "una

(C) UNED. Revista de Derecho UNED, núm. 26, 2020 
ber de declarar va acompañada de la falta de ingreso o de ingreso in-

ulterior Sentencia que justificase la sanción en todos sus extremos nunca podría venir a sustituir o de alguna manera sanar la falta de motivación del acto administrativo" [ STC 7/1998, de 13 de enero... y SSTS de 10 de diciembre de 2009 (rec. cas. núm. 3850/2004 ); y de 14 de abril de 2011 (rec. cas. núm. 2507/2009 )]. Y es que, efectivamente, el máximo intérprete de nuestra Constitución viene advirtiendo sobre "la inadecuación constitucional de considerar que el proceso judicial de impugnación de una sanción administrativa subsane las lesiones del art. 24.2 CE causadas en el ámbito del procedimiento administrativo sancionador supliendo sus deficiencias en el seno del propio proceso judicial, sustituyendo así en sus funciones propias a la Administración autora del acto, fiscalizado en el proceso". La razón estriba en que "no existe un proceso contencioso-administrativo sancionador en donde haya de actuarse el ius puniendi del Estado, sino un proceso contencioso-administrativo cuyo objeto lo constituye la revisión de un acto administrativo de imposición de una sanción. En consecuencia, no es posible concluir que sean los Tribunales contencioso- administrativos los que, al modo de lo que sucede en el orden jurisdiccional penal, «condenen» al administrado. Muy al contrario, la sanción administrativa la impone siempre la Administración pública en el ejercicio de la potestad que le reconoce la Constitución. De otra manera no se respetaría la exigencia constitucional de que toda sanción administrativa se adopte a través de un procedimiento que respete los principios esenciales reflejados en el art. 24 CE " ( STC 243/2007, de 10 de diciembre; en el mismo sentido, entre otras, SSTC 89/1995, de 6 de junio; 7/1998, de 13 de enero; y 35/2006, de 13 de febrero ) «. La más reciente STS 11 de junio de 2012 (recurso 588/2009, ponente Excmo. Sr. Huelin Martínez de Velasco) confirma la anterior doctrina sobre que la motivación de, al menos, la simple negligencia exigida por el artículo 77.1 de la Ley General Tributaria de 1963 debe encontrarse en el acuerdo sancionador, cuya insuficiencia no puede ser subsanada por los Tribunales Económico-Administrativos ni tampoco por los órganos judiciales (por todas, la sentencia de 29 de octubre de 2009 , casación 2422/03 ); sobre que la mera constatación de la falta de ingreso no permite fundar la imposición de sanciones tributarias, dado que éstas no pueden ser el resultado, poco menos que obligado, de cualquier incumplimiento de las obligaciones tributarias a cargo de los contribuyentes, insistiendo en la insuficiencia de la mera referencia al resultado de la regularización practicada por la Administración tributaria o en la simple constatación de la falta de un ingreso de la deuda tributaria, porque el mero hecho de dejar de ingresar no constituía en la Ley General Tributaria de 1963 -ni constituye ahora- infracción tributaria y porque no es posible sancionar por la mera referencia al resultado, sin motivar específicamente de dónde se colige la existencia de culpabilidad; y sobre que la no concurrencia de alguno de los supuestos del artículo 77.4 de la Ley General Tributaria de 1963 es insuficiente para fundamentar la sanción, porque el principio de presunción de inocencia garantizado en el artículo 24.2 de la Constitución española no permite que la Administración tributaria razone la existencia de culpabilidad por exclusión o, dicho de manera más precisa, mediante la afirmación de que la actuación del obligado tributario es culpable porque no se aprecia la existencia de una discrepancia interpretativa razonable, o la concurrencia de cualquiera de las otras causas excluyentes de la responsabilidad de las recogidas en el artículo 77.4 de la Ley General Tributaria de 1963 [actual artículo 179.2 Ley 58/2003, de 17 de diciembre, General Tributaria ], de donde se infiere que la circunstancia de que la norma incumplida sea clara o que la interpretación mantenida de la misma no se entienda razonable no permite imponer automáticamente una sanción tributaria porque es posible que, no obstante, el contribuyente haya actuado diligentemente. La aplicación al presente caso de la 
ferior $^{51}$ al debido. Esto es, probablemente, lo que indujo al redactor del precepto a su simplificación con el «dejar de ingresar» (simplificación que arranca desde la reforma de 1985), pero, como señaló la doctrina y posteriormente aclaró la Ley, la simple falta de ingreso no puede ser sancionable. Repetimos aquí lo que suele decirse en el análisis del delito fiscal: no existe en el Derecho moderno la prisión por deudas, ni, podríamos añadir, la multa por el simple dejar de ingresar.

Para nosotros ${ }^{52}$ esta infracción se considera como de resultado ${ }^{53} \mathrm{y}$ provocadora de un perjuicio directo a la Hacienda Pública ${ }^{54}$. Esta in-

anterior doctrina nos lleva a la estimación de la demanda y es que, sobre la base de que el acuerdo de imposición de sanción ha de ser literosuficiente en cuanto expresivo de los elementos objetivos y subjetivos que conforman la infracción, y la afirmación apodíctica de «dejar de ingresar la deuda tributaria» a modo de motivación no es admisible en un estado de derecho, a la simple lectura del art. 9 CE \#78. No colma, desde luego, las mencionadas exigencias sobre respeto al principio de culpabilidad al no especificar, con el suficiente grado de detalle que la imposición de una medida punitiva merece, en qué consistieron los importantes errores determinantes de un incorrecto cálculo de la retención. De hecho, la motivación empleada en el acuerdo sancionador en realidad serviría respecto de la incorrección de cualquier obligación, razones que nos llevan a apreciar el defecto de insuficiente motivación denunciado y, con ello, a la estimación de la demanda. Es este criterio una reproducción de lo ya dicho en nuestra STSJ, Contencioso sección 3 del 05 de Septiembre del 2013 (ROJ: STSJ CL 3706/2013), Recurso: 1830/2009 | Ponente: Francisco Javier Pardo Muñoz."

51 La aplicación de exención a sabiendas de la improcedencia de la misma, cuando no cabe una interpretación razonable de la norma, será objeto de sanción (STSJ Castilla y León, Burgos, Sala de lo Contencioso-Administrativo, Sec. 2. ${ }^{a}$, 22.1.2010).

52 MARTÍN CÁCERES,A.F.:La prescripción...op.cit.pág.116.

53 Basarse en el mero resultado obtenido en el procedimiento inspector es insuficiente para entender acreditado el elemento subjetivo de la culpabilidad cuando dice que no se puede sancionar por el mero resultado (STSJ Murcia, Sala de lo Contencioso-Administrativo, Sec. 2. ${ }^{\mathrm{a}}, 1$ 17.5.2018).

54 La prueba de la culpabilidad y de la falta de ingreso de la deuda derivada de la pérdida de la reducción por la transmisión del inmueble hacen correcta la sanción en materia del impuesto de sucesiones (STSJ Castilla-León, Burgos, Sala de lo Contencioso-Administrativo, Sec. 2. $\left.{ }^{a}, 26.7 .2019\right)$. En igual sentido cabe indicar que "[l]a motivación de las sanciones tributarias es necesaria, sin que la mención del precepto aplicable subsane el error cometido, y sin que puedan alegarse las circunstancias subjetivas del contribuyente para alegar su conocimiento de ley y culpabilidad"(STSJ Murcia, Sala de lo Contencioso-Administrativo, Sec. 2. , 29.5.2019). La falta de la debida motivación del presupuesto de la culpabilidad en la sanción por la presentación fuera de plazo sin requerimiento de la declaración de bienes y derechos del recurrente en el extranjero, provoca la nulidad (STSJ Cataluña, Sala de lo Contencioso-Administrativo, Sec. 1. $\left.{ }^{a}, 27.5 .2019\right)$. Si bien es cierto que al recurrente no le asiste la razón en relación a la exención de las dietas y asignaciones controvertidas, se acuerda la nulidad de la sanción impuesta por no haberse motivado con suficiencia el elemento de culpabilidad (STSJ Castilla y León, Valladolid, Sala de lo Contencioso-Administrativo, Sec. 3. , 
fracción comprende ciertos comportamientos omisivos que provocan un perjuicio económico directo. Su consumación tiene lugar, por tanto, en la fecha en que el sujeto pasivo debía, lo más tarde, realizar la conducta exigida, esto es, el ingreso de la deuda, fecha que coincide con la causación del resultado que se debió evitar. Como se infiere del precepto citado, el transcurso del último día del plazo reglamentario sin que se verifique el ingreso determinaría la consumación de la conducta infractora, lo que significa que la prescripción de la acción para sancionarla comienza en el día siguiente a la finalización de dicho plazo. Ahora bien, esta fecha varía en función del modelo de gestión del tributo respecto del que se produce la infracción omisiva. Así las infracciones cometidas con ocasión de tributos gestionados mediante autoliquidación se consuma el día en que finaliza el plazo de presentación de la declaración liquidación. En otro caso, cuando el impuesto se gestiona por medio de liquidación administrativa, y aún cuando la omisión tiene lugar a través de la declaración, como ha señalado Pérez Royo, no puede afirmarse que la omisión se consuma con la presentación de la declaración, puesto que el precepto no está sancionando un acto preparatorio, sino la efectiva producción del resultado lesivo, que en puridad tiene lugar -y en consecuencia la omisión se consuma- en la fecha en que finaliza el plazo de pago voluntario. La prescripción de las infracciones cometidas bajo este modelo de gestión se iniciarán, pues, en el día siguiente a aquel en que este último plazo finalice.

Especial interés se ha de poner en la configuración normativa concreta de impuestos y tasas, y que del juego combinado del articulado, incluidos los anexos normativos, se satisfaga la reserva constitucional de ley, pues la norma legal, además de crear la figura tributaria concreta, deberá establecer las pautas generales para la determinación de sus elementos configuradores, como el hecho imponible, devengo, sujetos pasivos, base imponible, tipo de gravamen y cuota tributaria ${ }^{55}$, susceptibles de desarrollo y precisión a través de Reales Decretos. Sin embargo, cuando nada conste en la Ley acerca del modo de exacción y gestión del tributo ni, desde luego, sobre la

23.5.2019). El argumento es esencialmente estereotipado, incompleto en sus datos y en ningún caso especifica el motivo o causa de las incorrecciones apreciadas del acuerdo sancionador (TSJ Cataluña, Sala de lo Contencioso-Administrativo, Sec. $\left.1{ }^{\mathrm{a}}, 5.4 .2019\right)$. No se ha motivado con suficiencia la concurrencia de culpa o negligencia, lo que conduce a anular la sanción; entre otros aspectos el ISD experimentó cambios normativos durante el devengo (STSJ Madrid, Sala de lo Contencioso-Administrativo, Sec. 9. a , 31.1.2019).

55 Cuando no existe cuota, bien por falta de determinación, bien porque la determinada ha sido anulada, la sanción impuesta resulta improcedente (STSJ Asturias, Sala de lo Contencioso-Administrativo, Sec. 1. ${ }^{\mathrm{a}}$, 11.4.2011). 
obligación de los sujetos pasivos de presentar ante el órgano gestor la declaración correspondiente al periodo de devengo ${ }^{56}$, mal cabrá imputarle consecuencias al incumplimiento de esta inexistente obligación, previsiones que no pueden aparecen por primera vez en el articulado reglamentario ${ }^{57}$.

\subsection{Exención por regularización}

No está de más recordar que, como reiteradamente viene expresando la doctrina del Tribunal Supremo ${ }^{58}$ "no puede fundarse la existencia de infracción en la mera referencia al resultado de la regularización practicada por la Administración tributaria o en la simple constatación de la falta de un ingreso ${ }^{59}$ de la deuda tributa-

56 La imposición de la sanción es correcta, porque el contribuyente no declaró operaciones sujetas al IVA que no suscitaban dudas en cuanto a la fecha del devengo, dando lugar a una declaración inferior de la base imponible (STSJ Extremadura, Sala de lo Contencioso-Administrativo, Sec. 1. $\left.{ }^{\mathrm{a}}, 16.4 .2015\right)$.

57 Este es el caso de la STS de 25.02.2005, al tratar la tasa general de operadores en el sector de las telecomunicaciones, establecida en la Ley 32/2003 (art.29.1 y Anexo I.1) [hoy art. 31.1 y Anexo I.1de la Ley 9/2014, de 9 de mayo, General de Telecomunicaciones] y desarrollada en el Real Decreto 1620/2005 (art. 24.3).

58 Por todas, la STS de 28.01.2013 (FJ.4º, que confirma que esta Sala se viene pronunciando sobre cuestiones similares a la que nos ocupa habiéndose conformado un cuerpo doctrinal sobre la materia en el sentido de que no basta para justificar y acreditar la concurrencia del elemento subjetivo que las normas aplicables sean claras, precisando en numerosas ocasiones que....no era suficiente para fundamentar la sanción porque el principio de presunción de inocencia garantizado en el artículo 24.2 CE no permite [razonar] la existencia de culpabilidad por exclusión o, dicho de manera más precisa, mediante la afirmación de que la actuación del obligado tributario es culpable porque no se aprecia la existencia de una discrepancia interpretativa razonable ...o la concurrencia de cualquiera de las otras causas excluyentes de la responsabilidad...Así lo ha puesto de manifiesto, en términos que no dejan lugar a dudas, el Tribunal Constitucional en la [...] STC 164/2005, al señalar que se vulnera el derecho a la presunción de inocencia cuando se "impone la sanción por el mero hecho de no ingresar, pero sin acreditar la existencia de un mínimo de culpabilidad y de ánimo defraudatorio". En este punto, la STS de 15 de enero de 2009 recordaba las de 6 de junio de 2008 (casación para la unificación de doctrina 146/04, FJ 6º), 18 de abril de 2007 (casación 3267/02, FJ 8).

59 Un ejemplo lo encontramos en las SsTSJICAN 409 y 410, 7.10.2005, de cuyos FJ $5^{\circ}$ expresaron: QUINTO.- Ahora bien, la liquidación girada, una vez conocida por la AEAT la no existencia de cupo, incluyó intereses de demora. Entiende el TEAR en la resolución aquí impugnada que "siendo criterio general en nuestro ordenamiento interno la aplicación general de intereses de demora en los ingresos fuera del plazo en que debieron efectuarse, cuando su exigencia se hubiera derivado de la actuación comprobatoria o investigadora de la Administración» según los arts. 36.1, 61.2 y 77.5 de la LGT y el art. 69 del RD 939/1986, de 25 de abril , por el que se aprueba el Reglamento General de la Inspección de Tributos, procede su liquidación, condicionada a lo establecido en el art. 7 del Reglamento de la Comunidad Económica 
ria, porque el mero dejar de ingresar no constituía en la Ley General Tributaria de $1963^{60}$-ni constituye ahora- infracción tributaria, y porque no es posible sancionar por la mera referencia al resultado,

Europea 1197/1979, de 24 de julio , que requiere para su exigencia que el ingreso a posteriori no fuera debido a error de las autoridades competentes. Tal como se expone en la presente resolución, el procedimiento para la liquidación derivado del DUA presentado, requiere una serie de trámites que se verifican tanto ante la Administración Nacional como ante la Administración Europea, de lo que se deriva que la eficacia de la primera liquidación esté sujeta a una condición resolutoria, esto es, al informe de la Comisión en el que se indique si el contingente, cupo o saldo correspondiente está o no agotado, por lo que en el presente caso, dado su agotamiento, se procede por la Administración Nacional a girar la posterior liquidación, a la vista de la información remitida por las autoridades europeas, sin que se deba entender que el ingreso a practicar como consecuencia de dicha liquidación tenga la consideración de ingreso realizado fuera de plazo. Por ello debe ser estimado el recurso en este punto, en aplicación a sensu contrario de lo dispuesto en el art. 232 del Reglamento 2913/1992 de la Comisión , conforme al cual «cuando no se haya abonado el importe de derechos en el plazo establecido: b) se percibirá un interés de demora además del importe de derechos».

60 La LGT/2003 tipifica expresamente esta conducta, por lo que a partir de la entrada en vigor de la norma, se debe considerar como una infracción tributaria leve. En la LGT/1963 no estaba tipificada esta conducta, por lo que no se debe imponer la sanción tributaria, debiendo ser sustituida por los recargos correspondientes. La falta de tipificación en la LGT del ingreso fuera de plazo sin requerimiento previo en el momento de su comisión, anula la sanción y la sustituye por los recargos correspondientes (STSJ Cataluña, Sala de lo ContenciosoAdministrativo, Sec. 1. a , 11.6.2008). Al aplicarse la LGT de 1963, se debe sustituir la sanción tributaria y los correspondientes intereses de demora, con el recargo correspondiente (STSJ Cataluña, Sala de lo Contencioso-Administrativo, Sec. 1. a, 12.6.2008).Así eran anuladas las sanciones tributarias, porque la antigua LGT en declaraciones extemporáneas sólo exigía el ingreso sin requerimiento previo (SsTSJ Cataluña, Sala de lo Contencioso-Administrativo, Sec. 1. ${ }^{\mathrm{a}}$, 21.5.2008;y de 16.3.2006). Por el principio de retroactividad, es procedente la revisión de la sanción en los supuesto de regularización voluntaria sin requerimiento previo (STSJ Castilla-La Mancha, Sala de lo Contencioso-Administrativo, Sec. 2. ${ }^{\mathrm{a}}$, 30.4.2008). 
sin motivar ${ }^{61}$ específicamente de donde se colige la existencia ${ }^{62}$ de

61 Está motivada la resolución sancionadora porque indica que la sanción se debe a que el obligado declaró por el régimen simplificado de empresa de reducida dimensión cuando su facturación el año anterior había sido superior a $600.000 €$ (S TSJ Murcia, Sala de lo Contencioso-Administrativo, Sec. 2. ${ }^{a}, 30.11 .2017$ ). Los hechos e indicios reales y objetivamente constatados por la Inspección son prueba suficiente para comprobar la realidad de la falta de declaración de los ingresos y del fraude efectuado por la sociedad recurrente. No se trata de un mero error o de la realización de una interpretación razonable de la norma sino de la realización de una conducta voluntaria dirigida al incumplimiento de la norma (STSJ Extremadura, Sala de lo Contencioso-Administrativo, Sec. 1. ${ }^{\text {a }}$, 30.11.2017). La interpretación razonable de la norma constituye supuesto de exclusión de la responsabilidad por infracción tributaria, entendiendo la Administración que el obligado tributario ha puesto la diligencia necesaria en cumplir sus obligaciones. La ausencia de prueba justificativa de los costes declarados revela comportamiento negligente dándose la concurrencia del elemento objetivo y subjetivo de la conducta infractora dejar de ingresar dentro del plazo legal la deuda tributaria (STSJ Baleares, Sala de lo Contencioso-Administrativo, Sec. 1. $\left.{ }^{a}, 30.11 .2017\right)$. Falta motivación en las sanciones porque no recogen el elemento de culpabilidad sino que se limitan a señalar que el recurrente no declaró cuanto procedía determinados ingresos de IVA (STSJ Castilla y León, Valladolid, Sala de lo ContenciosoAdministrativo, Sec. 3. ${ }^{\text {, }}$ 28.4.2017). No están justificados algunos gastos deducibles porque las facturas en las que se incluyen en nada se asemejan a otras facturas del mismo proveedor y además son facturas pagadas en efectivo y no tener el proveedor esa estructura empresarial. Procede la sanción al concurrir culpa por haberse utilizado facturas falsas para deducir gastos (STSJ Asturias, Sala de lo ContenciosoAdministrativo, Sec. 1. a , 24.3.2017). Se excluye la imposición de sanciones por el mero resultado y sin atender a la conducta del contribuyente. No se motiva una sanción indicando que la conducta no puede atribuirse a interpretación razonable de la norma, ni a ninguna causa de exoneración de responsabilidad de acuerdo con la Ley (S TSJ Castilla y León, Valladolid, Sala de lo Contencioso-Administrativo, Sec. 1. a, $11.5 .2015)$. Procede la anulación de la sanción dado que la Administración indica la cantidad de retención que debería aplicar sin ofrecer método de cálculo y la norma no establece un procedimiento matemático claro para hallar aquella cuantía (STSJ Castilla y León, Valladolid, Sala de lo Contencioso-Administrativo, Sec. 1. $\left.{ }^{\mathrm{a}}, 11.5 .2015\right)$. La motivación del acuerdo sancionador es insuficiente porque se limita a constatar que para el cálculo de la base imponible del grupo consolidado no se tomó en cuenta la base imponible individual, sino un importe consolidado (STSJ Castilla y León, Valladolid, Sala de lo Contencioso-Administrativo, Sec. 3. , 10.4.2015). la providencia de apremio es nula puesto que parte de un título inválido, al no poderse liquidar el IVA sobre el año natural sin detallar cada trimestre (STSJ Baleares, Sala de lo Contencioso-Administrativo, Sec. 1. $\left.{ }^{\mathrm{a}}, 31.3 .2015\right)$. Se aprecia la alegada falta de motivación, anulándose el acuerdo sancionador, al no razonar por qué la interpretación del contribuyente es rechazable (STSJ Cataluña, Sala de lo Contencioso-Administrativo, Sec. 1. a , 19.9.2013). La sanción impuesta no está motivada puesto que, aunque menciona los hechos, el artículo que los tipifica y la cuantía de la sanción, omite el elemento intencional del sujeto sancionado (STSJ Galicia, Sala de lo Contencioso-Administrativo, Sec. 4. $\left.{ }^{\mathrm{a}}, 21.12 .2009\right)$.

62 STS, Sala Tercera, de lo Contencioso-Administrativo, Sec. 2. ${ }^{\text {a }}$ 2.2.2017; STSJ Madrid, Sala de lo Contencioso-Administrativo, Sec. 5. ${ }^{\mathrm{a}}, 1.2 .2017$; Procede sanción al aplicar el régimen de empresa de reducida dimensión cuando formaba parte de un grupo de sociedades. Concurre culpabilidad y motivación de la sanción (STSJ Madrid, Sala de lo Contencioso-Administrativo, Sec. 5. ${ }^{\text {, }}$ 30.11.2016). El acuerdo de 
imposición de sanción no está motivado porque no expresa los elementos objetivo y subjetivo que conforman la infracción ni especifica en qué consistió la conducta infractora y la omisión de la diligencia exigible (STSJ Castilla y León, Valladolid, Sala de lo Contencioso-Administrativo, Sec. 3. a , 28.11.2016). Las cartas de porte, cartas verdes, justificantes de matriculación o documentos del transportista no acreditan el hecho del transporte intracomunitario de vehículos: procedencia de la sanción tributaria impuesta (STSJ Comunidad Valenciana, Sala de lo ContenciosoAdministrativo, Sec. 3. a , 3.11.2016). Frente a las presunciones e indicios de la Administración pueden y deben practicarse medios de prueba suficientes para desvirtuar la prueba de indicios (STSJ Murcia, Sala de lo ContenciosoAdministrativo, Sec. 2. $\left.{ }^{\mathrm{a}}, 27.10 .2016\right)$. Revocación de sanción impuesta por existir duda razonable en la aplicación de las normas, no manteniendo, además, la Administración un criterio uniforme en la materia (IVA: cambio del epígrafe) [STSJ Castilla-La Mancha, Sala de lo Contencioso-Administrativo, Sec. 2. ${ }^{\mathrm{a}}$, 14.6.2016]. No existe prueba suficiente para acreditar que el vehículo turismo AUDI A3, cuyos gastos de gasolina, reparación y amortización pretende, se encontraba plenamente afecto a la actividad del interesado $\backslash$ Para la validez de la sanción por infracción tributaria era necesaria una motivación específica que no concurre, porque no se duda de la realización de algunos de los desplazamientos a las empresas a las que facturó sus servicios profesionales (STSJ Murcia, Sala de lo ContenciosoAdministrativo, Sec. 2. ${ }^{\mathrm{a}}$, 12.5.2016). Los importes de las facturas recibidas no se corresponden con el precio real de los servicios prestados por la persona física a la sociedad, por lo que el IVA no es deducible. La Inspección aplica el método de estimación directa para fijar los importes del IVA soportado no deducible y el de los gastos no deducibles en el IS, teniendo en cuenta los pagos acreditados con origen en una cuenta bancaria del contribuyente. La conducta del sujeto pasivo es culpable, y la buena fe o inexistencia de culpa, presumida por la Ley, queda destruida por la prueba de que el contribuyente no ha puesto la diligencia debida en el cumplimiento de sus obligaciones tributarias (STSJ Madrid, Sala de lo Contencioso-Administrativo, Sec. 5. a , 5.4.2016). Deducción de gastos por luz y agua dada la afección de la vivienda al ejercicio de la actividad profesión y de vehículo: dada las numerosas consultas DGT y de algún TSJ con opinión contraria, no se aprecia culpabilidad aunque sea fiscalista (STSJ Castilla y León, Burgos, Sala de lo Contencioso-Administrativo, Sec. 2. $\left.{ }^{\mathrm{a}}, 4.4 .2016\right)$. La interesada es sujeto pasivo del IEDMT por haber efectuado la $1^{\mathrm{a}}$ matriculación definitiva a su nombre en España de los vehículos objeto de comprobación -vehículos de demostración o prueba- acogiéndose improcedente al supuesto de no sujeción. Cada matriculación definitiva en España constituye un hecho imponible independiente por lo que hay 7 infracciones tributarias, una por cada cuota no ingresada (STSJ Castilla y León, Valladolid, Sala de lo Contencioso-Administrativo, Sec. 3. $\left.{ }^{\mathrm{a}}, 1.4 .2016\right)$. De la escritura de compraventa no resulta que la venta se hubiese perfeccionado con anterioridad a la misma, siendo que correspondía al interesado la prueba de que la transmisión se perfeccionó en fecha anterior, por lo que no existe prescripción. Se ha producido la conducta típica de la sanción, al haber dejado de ingresar la cuota que liquida la Inspección como consecuencia de haber omitido una parte sustancial del precio de venta de las fincas transmitidas mediante escritura pública (S TSJ Murcia, Sala de lo Contencioso-Administrativo, Sec. 2. ${ }^{a}, 23.3 .2016$ ). No procediendo la exención del IVA al no acreditarse que los bienes descritos en las facturas emitidas hayan sido transportados a otro Estado de la UE, ni que se haya cumplido el requisito de la correcta identificación del destinatario a efectos del IVA, concurre al menos negligencia por omisión del deber de cuidado mínimo exigible, máxime cuando se trata de una empresa habituada al tráfico comercial 
culpabilidad"63.

intracomunitario (STSJ Castilla-La Mancha, Sala de lo Contencioso-Administrativo, Sec. 1. $\left.{ }^{a}, 21.3 .2016\right)$. Se acredita el elemento subjetivo de la infracción porque se ha deducido cuotas de IVA soportado correspondientes a facturas irregulares emitidas por la persona física que no responden al coste real de los servicios prestado (STSJ Madrid, Sala de lo Contencioso-Administrativo, Sec. 5. a , 18.3.2016). La base de la sanción será la cuantía no ingresada en la autoliquidación como consecuencia de la comisión de la infracción (STSJ Madrid, Sala de lo ContenciosoAdministrativo, Sec. 5. a 18.3.2016). El comportamiento del interesado, conocedor de la normativa por su condición de profesional, evidencia la falta de cualquier mínimo interés y diligencia en el cumplimiento de sus obligaciones fiscales. En el caso de existir alguna duda sobre cómo efectuar el cálculo de la plantilla media, una mínima diligencia hubiese exigido una simple consulta a la Tesorería General de la Seguridad Social (STSJ Castilla y León, Burgos, Sala de lo ContenciosoAdministrativo, Sec. 2. ${ }^{a}$, 18.3.2016).

63 La motivación del acuerdo sancionador, pese a su aparente amplitud, no pasa de ser genérica y estereotipada, en tanto que es predicable de todos aquellos casos en que el obligado tributario deje de ingresar determinado tipo de deuda tributaria, la de las retenciones por IRPF a los trabajadores. En el caso enjuiciado concurrieron circunstancias particulares que merecían una consideración específica; en concreto las relacionadas con la situación concursal de la entidad sancionada y con las alegaciones que ella adujo para no haber ingresado la deuda tributaria, las cuales no pueden tenerse como manifiestamente irrazonables, sin que una discrepancia en estos términos pueda reprocharse por dolo o por culpa. (STSJ Comunidad Valenciana núm. 374/2017, de 19 de abril de 2017). La interpretación razonable de la norma constituye supuesto de exclusión de la responsabilidad por infracción tributaria, entendiendo la Administración que el obligado tributario ha puesto la diligencia necesaria en cumplir sus obligaciones. La ausencia de prueba justificativa de los costes declarados revela comportamiento negligente dándose la concurrencia del elemento objetivo y subjetivo de la conducta infractora dejar de ingresar dentro del plazo legal la deuda tributaria (STSJ Baleares, Sala de lo Contencioso-Administrativo, Sec. 1. $\left.{ }^{\mathrm{a}}, 30.11 .2017\right)$. El actor declaró una retención del trabajo que no era correcta, conociendo la verdadera retención que le había sido realizada por el pagador, y unas pérdidas por una actividad económica que no se acredita que se desarrollase de manera efectiva. No se trata de un mero error o interpretación razonable de la norma sino que se acredita una conducta dirigida de forma evidente a incumplir la norma para eludir la tributación correspondiente al IRPF, no actuó con la diligencia debida (S TSJ Extremadura, Sala de lo Contencioso-Administrativo, Sec. 1. $\left.{ }^{a}, 30.11 .2017\right)$. El Acuerdo sancionador está motivado al realizar una valoración individual de los hechos y de la conducta del sujeto pasivo para imponer la sanción en un supuesto donde la actuación del actor es reveladora de conducta dirigida a incumplir la norma (STSJ Extremadura, Sala de lo Contencioso-Administrativo, Sec. 1. , $^{\text {, }}$ 30.11.2017). La administración comprueba que el obligado ha obtenido ingresos como abogado no declarados, y opta por determinar el rendimiento por los cobros relacionados con la presentación de declaraciones a través de sus cuentas bancarias. La Administración no ha conseguido probar los ingresos de la actividad de abogado-asesor fiscal superiores a los declarados por el contribuyente, por lo que procede estimar correctas las liquidaciones del IRPF presentadas por el mismo (SsTSJ Castilla y León, Valladolid, Sala de lo Contencioso-Administrativo, Sec. 3. a, 23.11.2017 y 13.11.2017 ). Procede la sanción impuesta porque está debidamente motivada ya que el obligado omitió la presentación de la liquidación y el pago de las retenciones debidas $\backslash$ La infracción no puede ser calificada como leve sino como 


\section{Quedan exonerados de sanción por la infracción cometida cuando}

muy grave porque se dejó de ingresar más de un 50\% de la base de la sanción(S TSJ Madrid, Sala de lo Contencioso-Administrativo, Sec. 5. $\left.{ }^{\mathrm{a}}, 15.11 .2017\right)$. La base de la sanción será la cuantía no ingresada en la autoliquidación como consecuencia de la comisión de la infracción(SAN, Sala de lo Contencioso-Administrativo, Sec. 6. ${ }^{\text {, }}$, 7.11.2017). El requisito de la culpabilidad se da en el momento en que se emite el pagaré sin cláusula «no a la orden» (STSJ Aragón, Sala de lo ContenciosoAdministrativo, Sec. 2. $\left.{ }^{\mathrm{a}}, 31.10 .2017\right)$. Al existir en consecuencia un negocio simulado, se considere acreditada la existencia de culpabilidad o negligencia en dicha conducta y por tanto que se deba entender cometida la infracción del art. 191.1 LGT (S TSJ Murcia, Sala de lo Contencioso-Administrativo, Sec. 2. ${ }^{a}$, 26.10.2017). El Acuerdo sancionador está motivado porque hace una valoración individualizada de los hechos, de la conducta del sujeto pasivo, de la comisión dolosa de la infracción, califica la infracción y analiza los preceptos aplicables para imponer la sanción (S TSJ Extremadura, Sala de lo Contencioso-Administrativo, Sec. $\left.1{ }^{\mathrm{a}}, 26.10 .2017\right)$. Se ha producido la omisión de ingresos registrados en la actividad de abogacía como suplidos sin acreditar esta condición, lo que no es concebible sin la concurrencia de dolo, culpa o cuando menos de negligencia (STSJ La Rioja, Sala de lo Contencioso-Administrativo, Sec. 1. a , 3.10.2017). En la factura no se concretan suficientemente los servicios prestados pese a que su coste era ciertamente elevado con lo que tampoco puede decirse que se haya acreditado su necesariedad para obtener los ingresos de la empresa. Queda acreditada la culpabilidad o negligencia en la conducta de la actora, dejar de ingresar la deuda tributaria resultante de la liquidación girada por regularización sin que exista interpretación razonable de la norma que excluya la culpabilidad (STSJ Murcia, Sala de lo Contencioso-Administrativo, Sec. 2. ${ }^{\mathrm{a}}$, 21.9.2017). No procede la imposición de sanción porque la Administración no justifica la culpabilidad porque es una fórmula preestablecida y la obligada tenía más de 80 años, está enferma, no consta que recibiera el borrador y pagó de inmediato (STSJ Castilla y León, Valladolid, Sala de lo Contencioso-Administrativo, Sec. 3. $\left.{ }^{a}, 15.9 .2017\right)$. El acuerdo sancionados está suficientemente motivado y concurre el elemento de culpabilidad por deducirse gastos en unas facturas falsas (STSJ Castilla y León, Valladolid, Sala de lo Contencioso-Administrativo, Sec. 3. ${ }^{\text {a }}$ 28.7.2017). Procede la imposición de sanción porque la única finalidad de crear la sociedad profesional se ha acreditado que era para reducir la carga fiscal y que, además, no se han valorado correctamente las operaciones vinculadas (STSJ Madrid, Sala de lo ContenciosoAdministrativo, Sec. 5. $\left.{ }^{a}, 6.7 .2017\right)$. Deducción de factura falsa o falseada: correcta motivación de la culpabilidad y calificación de la infracción muy grave, al apreciar la utilización de medios fraudulentos (STS, Sala Tercera, de lo ContenciosoAdministrativo, Sec. 2. ${ }^{\mathrm{a}}$, 30.6.2017). Los motivos aducidos en el acuerdo sancionador se refieren a la falta de diligencia necesaria para calcular las retenciones y los servicios que pone la Administración a disposición de los contribuyentes pero sin detallar debidamente en qué ha consistido (STSJ Murcia, Sala de lo Contencioso-Administrativo, Sec. 2. ${ }^{\mathrm{a}}$, 22.6.2017). Procede la imposición de sanción porque los recurrentes no declararon las ganancias patrimoniales obtenidas con el pago del justiprecio de la expropiación y los intereses de demora y no cabe una interpretación razonable de la norma que exima del pago (STSJ Madrid, Sala de lo Contencioso-Administrativo, Sec. 5. $\left.{ }^{a}, 13-3-2017\right)$. Se ha acreditado que la actividad del recurrente no es solo la de diseñador gráfico, expresamente incluido en el régimen de estimación objetiva, sino también la de publicidad que es una actividad profesional y debe tributar por estimación. Procede imponer la sanción porque el recurrente se amparó en un régimen que le permitía una tributación más reducida sabiendo que no cumplía con los requisitos para ello 
(STSJ Madrid, Sala de lo Contencioso-Administrativo, Sec. 5. a 9.3.2017). No procede deducir las facturas de la sociedad porque se ha acreditado que los servicios no se han prestado ya que la sociedad que facturó pertenece al grupo de la recurrente y no tiene infraestructura para prestar los servicios. Procede la sanción porque se han deducido cuotas de IVA por servicios que no son reales y se ha tratado de ocultar este dato a la Administración (STSJ Madrid, Sala de lo Contencioso-Administrativo, Sec. 5. ${ }^{\text {a }}$, 9.3.2017). Procede la sanción porque en la inspección se ha acreditado que se hicieron facturas falsas y es ese acuerdo el que debería recurrirse si no se está de acuerdo con la declaración de falsedad y no la sanción (STSJ Madrid, Sala de lo Contencioso-Administrativo, Sec. 5. a , 14.2.2017). El acuerdo sancionador está suficientemente motivado al describir hechos que ponen de manifiesto omisión de diligencia y actuación dolosa como deducción de gastos documentados en facturas que reflejan servicios cuya realización no se ha efectuado (STSJ Castilla y León, Valladolid, Sala de lo Contencioso-Administrativo, Sec. 3. $\left.{ }^{a}, 13.2 .2017\right)$. No puede hablarse de una interpretación razonable de la norma o de una ausencia de culpabilidad puesto que la interesada se está beneficiando de la emisión de unas facturas que no reflejan la realidad de la operación realizada (STSJ Murcia, Sala de lo Contencioso-Administrativo, Sec. 2. ${ }^{\mathrm{a}}, 2$ 29.1.2016). Ante supuestos de simulación, no cabe permitir razonabilidad alguna, tratándose de un comportamiento doloso, dirigido intencionadamente a eludir las consecuencias impuestas por las normas tributarias (S TSJ Castilla y León, Valladolid, Sala de lo Contencioso-Administrativo, Sec. 3. a, 4.5.2015). Presentó el documento a liquidación, recogiendo la operación tal y como quedó redactada en la escritura, pero como la distribución del crédito hipotecario es dudosa, no cabe apreciar culpabilidad por la falta de ingreso (STSJ Castilla y León, Valladolid, Sala de lo Contencioso-Administrativo, Sec. 2. $\left.{ }^{a}, 23.7 .2014\right)$. El acuerdo sancionador justifica adecuadamente la culpabilidad, pues constituye, al menos, una evidente omisión de la diligencia exigible la deducción de cuotas que no guardan relación con bienes afectos a la actividad empresarial (STSJ Madrid, Sala de lo ContenciosoAdministrativo, Sec. 5. $\left.{ }^{\text {a }}, 8.7 .2014\right)$. La sanción es procedente, porque la vivienda no fue residencia habitual en el período exigido legalmente, por lo que la actuación del interesado ha de calificarse al menos como negligente (STSJ Castilla y León, Burgos, Sala de lo Contencioso-Administrativo, Sec. 2. ${ }^{a}$, 2.5.2014). No basta con que la Inspección alegue genéricamente las incorrecciones cometidas para que resulte procedente la sanción, sino que es preciso que se especifiquen las razones por las que se considera que constituyen infracción tributaria (STSJ Castilla y León, Valladolid, Sala de lo Contencioso-Administrativo, Sec. 3. ${ }^{\text {a }}$ 26.4.2013). El contrato entre la empresa y la conserjería de obras públicas constituye una concesión de obra pública, por lo que el negocio se incardina dentro del hecho imponible del ITP. La contratista tiene la obligación de entregar la instalación construida a la Administración en un plazo de 25 años, así la base imponible resultará del valor neto contable de los elementos a revertir, aplicando las tablas de amortización del IS. La infracción tributaria es procedente porque existe culpa o falta de diligencia exigible a la hora de consignar las cantidades del hecho imponible, al presentarse una autoliquidación por cuantía muy inferior a la debida (STSJ Baleares, Sala de lo Contencioso-Administrativo, Sec. 1. $\left.{ }^{\mathrm{a}}, 10.12 .2012\right)$. No ha quedado acreditado el error de traspaso del ejercicio precedente para justificar la compensación de pérdidas de las sociedades patrimoniales (STSJ Cataluña, Sala de lo ContenciosoAdministrativo, Sec. 1. a , 14.6.2012). No procede la exención por reinversión de la vivienda habitual porque se vendió antes de 3 años, y el traslado para obtener los puntos para que su hijo se pueda matricular en el colegio no supone una situación de necesidad. La calificación de la vivienda como rentas inmobiliarias imputadas es 
se regularice ${ }^{64}$ la situación mediante la presentación de declaración o

improcedente, porque la ley no contiene una definición del concepto de vivienda habitual. No procede la imposición de la sanción porque el interesado actuó en el convencimiento de que se ejercía un derecho constitucional, lo que excluye la culpabilidad (STSJ Cataluña, Sala de lo Contencioso-Administrativo, Sec. 1. a, 12.1.2012). La alegación de la existencia de error involuntario no puede eximir de responsabilidad por la infracción tributaria, pues mediante un comportamiento diligente pudo evitarse el resultado. La conducta ilícita no se vio agravada por la ocultación, por lo que la calificación de la conducta es de infracción tributaria leve con imposición de una multa del 50\% (STSJ Andalucía, Granada, Sala de lo Contencioso-Administrativo, Sec. 2. $\left.{ }^{a}, 26.9 .2011\right)$. Calificación de un rendimiento como irregular. No dedicación a la profesión de la que traen causa los ingresos, y rendimientos obtenidos durante mas de 2 años, No es sancionable la falta de ingreso de la deuda por error en la calificación, al existir diligencia del deudor, es decir, falta de culpabilidad (STSJ Castilla y León, Burgos, Sala de lo ContenciosoAdministrativo, Sec. 2. ${ }^{\mathrm{a}}$, 4.5.2009). Los beneficiarios de exenciones y tipos reducidos en los Impuestos Especiales que por incumplimiento de las condiciones de estos beneficios estén obligados al pago del impuesto de acuerdo con el artículo 8.6 de la LIE, si estuvieren obligados a presentar la correspondiente autoliquidación y dejan de ingresar la deuda tributaria, cometen una conducta que, en su caso y acreditada por la Administración la concurrencia del elemento subjetivo de la culpabilidad, encajaría dentro del tipo de la infracción regulada en el artículo 191 de la Ley 58/2003, de 17 de diciembre, General Tributaria (RTEAC 21.1.2016).

64 Se acredita que la sociedad demandante ha incumplido la norma tributaria al no abonar las cuotas dentro de plazo, regularizando su situación cuando fue requerida por la Administración (STSJ Extremadura, Sala de lo ContenciosoAdministrativo, Sec. 1. $\left.{ }^{\mathrm{a}}, 31.3 .2016\right)$. La jurisprudencia dice que existe un terreno en curso de urbanización desde el inicio de las obras, pero hay una sentencia de la AN que dice que la aprobación del Plan Parcial determina la calificación de los terrenos como en curso de urbanización. Se anula la infracción tributaria por dejar de ingresar dentro del plazo la deuda tributaria, debido a que el contribuyente ha realizado una interpretación razonable de la norma (STSJ Castilla y León, Valladolid, Sala de lo Contencioso-Administrativo, Sec. 2. a 30.4.2014). La sanción basada en que no se ha actuado con el cuidado y la atención exigibles para la correcta aplicación de la deducción en el IS, sin que se aprecien otras causas de exoneración de la responsabilidad, no respeta el principio de culpabilidad (STSJ Castilla y León, Valladolid, Sala de lo Contencioso-Administrativo, Sec. 3. $\left.{ }^{\mathrm{a}}, 11.4 .2014\right)$. Se anula la sanción tributaria porque existe duda interpretativa acerca del concepto "anejos e instalaciones y servicios complementarios» situados en las edificaciones destinadas principalmente a viviendas, y en concreto acerca de las piscinas (STSJ Baleares, Sala de lo Contencioso-Administrativo, Sec. 1. a, 23.10.2013). El hecho de haberse admitido en esta resolución que la Inspección debió proceder a la regularización íntegra para determinar el derecho del obligado tributario a obtener la devolución del IVA ingresado de forma indebida, no excluye la posibilidad de sancionar por la conducta regularizada (deducir improcedente unas cuotas que dieron lugar a una liquidación con resultado a ingresar a favor de la Hacienda Pública), pues habrá que analizar la conducta del obligado tributario en si misma para determinar si cabe imponer sanción por ella, con independencia de que en el Acuerdo dictado por la Inspección e impugnado en esta vía económicoadministrativa la cantidad a ingresar deba minorarse por el derecho de la entidad a obtener la devolución del IVA ingresado de forma indebida, en la forma expuesta en la resolución (RTEAC 14.12.2017). 
autoliquidación extemporánea sin requerimiento ${ }^{65}$ previo de la Administración tributaria ${ }^{66} \mathrm{O}$ cuando se presente correctamente ${ }^{67} \mathrm{la}$ correspondiente autoliquidación en plazo con resultado a ingresar sin realizar el ingreso de todo o parte de la deuda que de la misma resulta $^{68}$. Explicita el artículo $191.1^{\circ} .1$ LGT que la infracción ${ }^{69}$ tributaria por dejar de ingresar dentro del plazo establecido en la nor-

65 Es de aplicación la sanción tributaria cuando se trata de justificar el impago con el extravío de la declaración, pero no se efectúa el mismo hasta ser requeridos por la Administración Tributaria (S TSJ Asturias, Sala de lo Contencioso-Administrativo, Sec. 1. $\left.{ }^{\mathrm{a}}, 27.3 .2009\right)$.

66 Según el artículo 27 LGT, siempre que identifique expresamente el período de liquidación al que se refiere y que contenga únicamente los datos relativos a dicho período, y sin perjuicio de que la Administración liquide el recargo que proceda por la presentación extemporánea de la autoliquidación. MEMENTO PRÁCTICO FRANCIS LEFEBVRE. Inspección ...op.cit. pág. 333.

67 Para ello han de cuantificar el porcentaje de recargo en función de la demora que exista desde la finalización del plazo de declaración hasta el momento de la presentación de la declaración o autoliquidación....En los procedimientos de gestión tributaria (iniciado mediante declaración, de verificación de datos o de comprobación limitada), el plazo de resolución es de seis meses, cuyo incumplimiento produce la caducidad del procedimiento, por lo que ni se entiende producida la interrupción de la prescripción del derecho de la Administración a regularizar la situación tributaria del obligado tributario ni la acción para sancionar las conductas tributarias, y, además en caso de que el obligado tributario hubiera presentado declaración o autoliquidaciones después del requerimiento, se recalificarían dichas declaraciones y tendrán la consideración de extemporáneas y voluntarias, por lo que les serán de aplicación los recargos del artículo 27 LGT,, y por tanto, no serán sancionables. Lo mismo ocurre en el procedimiento de inspección tributaria, cuyo plazo máximo de duración es de doce meses, ampliable por otros doce (art. 150.1 LGT) [hoy 18 o 27 meses], transcurrido el cual, o también el plazo de seis meses de interrupción injustificada por causa no imputable al obligado tributario (art. 150.2 LGT) [interrupción inexistente hoy día, pero sí cabe extender los plazos por un máximo de hasta seis meses en los supuestos de los apartados $4^{\circ}$ y $5^{\circ}$ del art. 150 LGT], no se considerará interrumpida la prescripción y los ingresos podrecidos hasta la reanudación de las actuaciones inspectoras tendrán la consideración de espontáneos, siempre que el obligado tributario impute dichos ingresos al tributo y período objeto de las actuaciones [hoy esta redacción se encuentra en el art. 150.6.b LGT]. DİEZ OCHOA, J.M.: Derecho Tributario ...op.cit.págs. 260 a 262.

68 De considerar la conducta de no ingresar como infracción se estaría sancionando la falta de liquidez o solvencia y no la presentación de una declaración incorrecta. De ser correcta, se inicia el período ejecutivo establecido en el artículo 161.1.b) LGT, con los oportunos recargos ejecutivos del artículo 28 LGT.

69 La falta de ingreso de la deuda tributaria por cada período de IVA, al tratarse de cuotas independientes, constituyen distintas infracciones, lo que tiene transcendencia respecto a la prescripción. Antes de la entrada en vigor de la LGT/2003, bastaba el ingreso, aunque se hiciera fuera de plazo, pero sin requerimiento previo, para que se sustituyera la sanción por el recargo correspondiente (STSJ Cataluña, Sala de lo Contencioso-Administrativo, Sec. 1. a, 31.7.2009; S TSJ Asturias, Sala de lo Contencioso-Administrativo, Sec. 1. a, 22.6.2009). 
mativa de cada tributo ${ }^{70}$ la totalidad o parte de la deuda tributaria que debiera resultar de la correcta ${ }^{71}$ autoliquidación del tributo, dejará de ser tal infracción cuando se regularice ${ }^{72}$ con arreglo al artículo 27 -por declaración extemporánea sin requerimiento previo ${ }^{73}$-o

70 Un ejemplo sobre el cómputo de dicho plazo lo podemos encontrar en la SAN DE 13.06.2011 (asunto JUVER), en la que se aplica supletoriamente para el cómputo de plazos el Código Civil, y además entra a considerar el principio de confianza legítima y de interpretación razonable de la norma de cómputo de plazos basada en el Manual del Impuesto de Sociedades publicado por AEAT.

71 Cuando cuotas de IVA soportadas en un determinado período son incluidas en declaraciones de períodos posteriores, es de aplicación el régimen de sanciones y no el régimen de recargos por declaración extemporánea sin requerimiento (RTEAC, Vocalía 4. a , 22.2.2011). No existe regularización cuando el sujeto pasivo se limita a incluir lo no declarado en trimestres anteriores en el cuarto trimestre del IVA del ejercicio objeto de inspección \La declaración anual de IVA no supone una ratificación de los trimestres de IVA, pues mediante el resumen anual y el ingreso se pretende subsanar omisiones en las liquidaciones trimestrales (STSJ Aragón, Sala de lo Contencioso-Administrativo, Sec. 2. ${ }^{a}$, 17.11.2010; con un voto particular).

72 El acuerdo sancionador incorpora una motivación específica vinculando los hechos determinantes de la regularización con la conducta que estima culpable y razona con referencia a datos concretos en qué extremos se basa la existencia de culpabilidad. El recargo por ingreso extemporáneo sin requerimiento es una deuda autónoma e independiente accesoria de aquella vinculada a la presentación de declaraciones y autoliquidaciones fuera de plazo sin requerimiento (STSJ Madrid, Sala de lo Contencioso-Administrativo, Sec. 5. ${ }^{\mathrm{a}}, 26.1 .2017$ ).

${ }_{73}$ Equiparando voluntariedad a falta de requerimiento administrativo. MANCHO ROJO,R.: El régimen sancionador tributario y su aplicación a las haciendas locales, Fundación Asesores Locales, Málaga, 2005, pág.78; Según la SAN de 22 de octubre de 2009, la falta de modelo oficial aprobado para autoliquidar la deuda, excluye la aplicación del recargo por ingreso extemporáneo; ESEVERRI de modo tajante expone que "[d]ebe aclararse por último, que aunque la exposición que se acaba de realizar está referida esencialmente a los casos de declaraciones y autoliquidaciones complementarias, el régimen de recargos descrito (del art. 27 LGT) es de aplicaciones a aquellas declaraciones o autoliquidaciones iniciales (no complementarias) que se presenten fuera de plazo y sin requerimiento de la Administración, esto es, al de aquellas en las que previamente y en plazo no se presentó declaración o autoliquidación ninguna, efectuándose por vez primera fuera del plazo legalmente establecido. En tales casos y en lo concerniente a la exclusión de responsabilidad punitiva, el art. 179.3 LGT es taxativo al señalar que no incurre en responsabilidad por infracciones tributarias quienes de forma voluntaria regularicen su situación tributaria mediante la presentación de declaraciones o autoliquidaciones fuera de plazo”. ESEVERRI MARTÍNEZ,E.: Derecho Tributario. Parte General, Tirant lo Blanch, Valencia, 2011, pág.336. El pago extemporáneo sin requerimiento previo, constituye una infracción tributaria cuando el sujeto pasivo no identifica expresamente el periodo impositivo en la declaración y ésta no contiene únicamente los datos relativos a dicho periodo. No es suficiente la motivación de la sanción basada en que la entidad es una gran empresa e ingresó trimestralmente las declaraciones de IVA, cuando tiene que ingresar mensualmente (STSJ Madrid, Sala de lo Contencioso-Administrativo, Sec. 5. $\left.{ }^{\mathrm{a}}, 12.2 .2013\right)$. 
proceda la aplicación del párrafo b) del apartado 1 del artículo 161 LGT- por iniciación del período ejecutivo- ${ }^{74}$.

Según lo indicado contemplamos dos supuestos de regularización, de un lado la voluntaria con ingreso ${ }^{75}$ del artículo 27 LGT, que entendemos que no excluye la infracción, que siempre existirá por mor del artículo $27.2^{\circ}$ LGT, sino la sanción ${ }^{76}$. De otro, el del artículo

74 En este caso, tampoco procederá sanción alguna por la cantidad total o parcialmente no ingresada, sino que se exigirá el recargo del período ejecutivo más los correspondientes intereses de demora que en su caso procedan según las reglas de cálculo de los arts. 28 y 26, respectivamente, de la LGT. MANCHO ROJO,R.: El régimen sancionador...op.cit.pág.79; En relación a la regularización encubierta o imperfecta, podríamos considerar que la circunstancia de calificación a que refiere el artículo 191.6 LGT reviste especiales caracteres respecto de la conducta del sujeto infractor que califican el tipo. Sin embargo, dicha conducta igualmente cabría entenderla que es nueva y distinta de la del tipo principal en cuyo caso nos encontraríamos ante un tipo específico. LAMOCA concluye que en ambos casos se está calificando, una el tipo general, la otra los tipos específicos del precepto. Para ello habría que partir de que cada artículo regula una misma conducta con diferentes acciones, sólo así podríamos concluir que el artículo 191.6 LGT contempla un tipo calificado de específico. Si se parte de que la acción consiste en dejar de ingresar con exclusión d responsabilidad por arrepentimiento imperfecto formal y voluntario. Por último considera el autor que el artículo 191.6 LGT es un tipo específico incluido en el artículo donde la conducta general es dejar de ingresar. LAMOCA PÉREZ,C.: Infracciones...op.cit.pág. 186; con todo acierto señala Pérez Royo, que nos hallamos ante una infracción de resultado -como también lo son la de incumplimiento de declaración y pago, u obtención de devoluciones indebidas, al exigir todas ellas que la acción vaya seguida de un resultado separable espacio-temporalmente de la conducta-. Lo que se castiga no es sólo la falta de ingresos (dejar de ingresar), sino el incumplimiento de la obligación de autoliquidar que produce o posibilita el resultado cierto y efectivo de la falta de ingreso en los plazos queridos por la Ley. Falta de autoliquidación completa y veraz y falta real y efectiva del ingreso son los dos elementos esenciales que configuran el núcleo de la acción que,...se tipifica como infracción leve, grave o muy grave. FERREIRO LAPATZA, J.J.: ... Instituciones. ..., 2006, op.cit.págs.557 y 560; La RTEAC de 02.03.2005 ha dispuesto que no cabe afirmar que la regla específica contenida en la DT $1^{\text {a }}$ LGT prime sobre la genérica de su art. 10.2 LGT. Por tanto, según el citado tribunal, el nuevo régimen de recargos del período ejecutivo sí despliega efectos retroactivos, en los términos del art. 10.2 LGT. AA.VV. (Coord. PELÁEZ MARTOS, J.M ${ }^{\mathrm{a}}$.): Todo procedimiento...op.cit.págs. 852.853 .

75 Ingreso que podrá efectuarse en efectivo (art. 34 RGR), en efectos timbrados (art. 39RGR, cuando proceda) o en especie (arts. 40 RGR; 60.2 LGT; 73 Ley 16/1985, de 25 de junio, del Patrimonio Histórico Español [art. 65 del Real Decreto 111/1986, de 10 de enero, de desarrollo parcial de la Ley 16/1985, de 25 de junio, del Patrimonio Histórico Español] -bastando en este último caso una mera solicitud, sin perjuicio del requerimiento que corresponda realizar-. AA.VV. (Coord. PELÁEZ MARTOS, J.M ${ }^{\mathrm{a}}$.): Todo procedimiento...op.cit. págs. 855-856.

76 El tipo infractor debe ser entendido dentro de una interpretación histórica. En un primer momento, los ingresos fuera de plazo sin requerimiento previo comportaban, simplemente, el abono del interés de demora aunque el resultado de aplicar dicho interés no podía ser inferior al diez por ciento de la deuda tributaria. Ello supuso la introducción de una causa de no punibilidad o excusa absolutoria al 
161.1.b) LGT, referido a la regularización voluntaria sin ingreso de autoliquidaciones con cuota tributaria, en cuyo caso serán exigibles los recargos del período ejecutivo establecidos en el artículo 28 de la LGT -aunque debe tenerse en cuenta que para que proceda este recargo no es necesario que el mismo se ingrese antes de la notificación de la providencia de apremio, lo que debe ingresarse, en su totalidad, antes de dicha notificación, es sólo el principal pendiente por la deuda no satisfecha en período voluntario ${ }^{77}$. Reiteramos que el artículo 180.3 LGT declara la compatibilidad entre las sanciones derivadas de la comisión de infracciones y los recargos del período ejecutivo, por lo que parece ser que, inicialmente, no habría lugar a incompatibilidad entre sanción y recargo. Sin embargo, por idéntica argumentación que para el artículo 27.1 LGT -por así sostenerlo la doctrina constitucional-, la iniciación del período ejecutivo y sus recargos no tendrían naturaleza sancionadora, resultando compatibles, aunque el legislador ha preferido excluir la responsabilidad, o penalidad, económica a dichos supuestos.

El artículo 2 RGRST se refiere a la incoación del procedimiento sancionador tributario al transmitir que no existe la regularización voluntaria a que refiere el artículo $179.3^{\circ}$ LGT, y que el tenor del artículo 27.1.1 ${ }^{\circ}$ LGT permite entender regularizada una deuda sin requerimiento previo aún cuando se haya incoado un procedimiento sancionador, siempre que no se trate de una "actuación administrativa realizada con conocimiento formal del obligado tributario conducente al reconocimiento, regularización, comprobación, inspección $^{78}$, aseguramiento o liquidación de la deuda tributaria”, entre las

excluir la sanción en un supuesto en el que se cometía la infracción, y por lo tanto, una importante modificación indirecta del tipo de infracción grave. COLLADO YURRITA,M.A.: "Los intereses de demora en la Ley General Tributaria", Civitas$R E D F$, núm. 56, 1987, pág. 504; RODRÍGUEZ MÁRQUEZ,J.: El interés de demora en la Ley General Tributaria, Marcial Pons, 1998, Madrid, pág. 196; LOZANO CUTANDA,B.: "El art. 61.2 de la LGT: la exención de penalidad de los ingresos tardíos sin requerimiento previo", Civitas-REDF, núm. 63, 1989, pág. 363; LOZANO, B.: La extinción ...op.cit., pág 141; todos ellos citados por ANEIROS PEREIRA,J.: Las sanciones ...op.cit. pág. 74; Para HERRERA MOLINA la infracción siempre será leve, sea cual sea la cuantía a que ascienda la falta de ingreso en plazo de tributos o pagos a cuenta que hubieran sido incluidos o regularizados por el mismo obligado tributario en una autoliquidación presentada con posterioridad, sin que se haya dado un previo requerimiento administrativo, pero sin cumplir los requisitos establecidos en el art. 27.4 LGT para la aplicación de los recargos por declaración extemporánea sin requerimiento previo. AA.VV. (Dir. HERRERA MOLINA,P.M.): Factbook Fiscal... 2004, op.cit. pág. 292.

77 AA.VV. (Coord. PELÁEZ MARTOS, J.Mª): Todo procedimiento..op.cit.pág. 853.

78 El ingreso de cuotas después de haber comunicado el inicio de actuaciones inspectoras, es sancionable, aunque Gestión haya liquidado los recargos 
que no se encuentra el inicio del procedimiento sancionador. En los casos de incoación de procedimiento sancionador sin regularización previa a la notificación de la incoación de alguno de los procedimientos a que refiere el artículo 27.1.1 ${ }^{\circ} \mathrm{LGT}$, podrá aprovecharse de dicha circunstancia el sujeto infractor para exonerarse de responsabilidad por infracción tributaria, extinguiéndola. Estas mismas apreciaciones caben entenderlas efectuadas para el supuesto del artículo 192.1 ${ }^{\circ}$ LGT, que seguidamente comentamos.

Debemos diferenciar la eximente completa de la regularización encubierta del artículo 191.6 de la LGT $^{79}$ que, si bien concede un cierto $^{80}$ beneficio al infractor cual es considerar leve la infracción,

por presentación fuera de plazo (STS 18.05 .1999 y 19.12.2002); No procede sanción si se presentan declaraciones complementarias de un período que no es objeto de actuaciones inspectoras, aunque posteriormente se haya ampliado al mismo. (RTEAC 28.01.2000) AA.VV. (Coord. PELÁEZ MARTOS, J.M ${ }^{\mathrm{a}}$.): Todo procedimiento...op.cit.pág.717.

79 El art. 191.6 sólo contempla la regularización «por el mismo obligado tributario" (de lo que debe deducirse que la norma resulta aplicable a la falta de ingreso de pagos fraccionados, pero no a la falta de ingreso de retenciones o ingresos a cuenta). BAENA AGUILAR,A.: "Las regularizaciones espontáneas «informales» y la nueva Ley General Tributaria”, JT, núm. 11, 2004.

80 Por su importancia, reproducimos el FJ $5^{\circ}$ del ATC 20/2015, de 3 de febrero [cuestión de inconstitucionalidad respecto del art. 191.6 de la Ley 58/2003, de 17 de diciembre, general tributaria (LGT en lo que sigue), en relación con el art. 191.1.4 y 191.2 in fine, del mismo texto legal, por posible vulneración de los arts. 14, 31.1, 9.3 y 25.1 CE.]: Finalmente, en cuanto al reproche de arbitrariedad en sentido estricto (art. 9.3 CE), hemos reiterado que la calificación de "arbitraria" dada a una ley exige una cierta prudencia, toda vez que es la "expresión de la voluntad popular", por lo que su control de constitucionalidad debe ejercerse sin imponer constricciones indebidas al poder legislativo y respetando sus opciones políticas, centrándose "en verificar si el precepto cuestionado establece una discriminación, pues la discriminación entraña siempre una arbitrariedad, o bien, si aun no estableciéndola, carece de toda explicación racional, lo que también evidentemente supondría una arbitrariedad, sin que sea pertinente un análisis a fondo de todas las motivaciones posibles de la norma y de todas sus eventuales consecuencias" (STC 45/2007, de 1 de marzo, FJ 4, y ATC 123/2009, de 30 de abril, FJ 8). El art. 191.6 LGT sanciona la conducta consistente en ingresar fuera de plazo tributos o pagos regularizados por el propio obligado tributario pero sin cumplir los requisitos exigidos en el art. 27.4 LGT, esto es, sin que por parte de éste se identifique en la autoliquidación de forma expresa el período impositivo de liquidación al que se refieren los tributos o pagos que han sido regularizados. Se trata así de un tipo de infracción específica, que sanciona la conducta de quien intenta enmascarar la falta de ingreso en el momento adecuado incluyendo los pagos tardíos en otro período de liquidación, todo ello con la finalidad de evitar, de manera fraudulenta, la liquidación de los correspondientes recargos por presentación extemporánea de la autoliquidación. Como destaca el Fiscal General del Estado en su escrito, se trata de una conducta cuya antijuridicidad consiste en tratar de soslayar el régimen jurídico de las regularizaciones del art. 27 LGT, en los términos que también ha reiterado la doctrina del Tribunal Supremo referida a esta concreta infracción (entre otras, 


\section{no exime de modo íntegro de la responsabilidad infractora ${ }^{81}$. Algún}

SSTS de 14 de julio de 2011, dictada en el recurso de casación para la unificación de doctrina núm. 91-2008; y de 18 de julio de 2011, dictada en recurso de casación para la unificación de doctrina núm. 130-2008). No se trata así de un mero retraso en el pago sino que éste viene cualificado por el encubrimiento deliberado de los ingresos de un ejercicio en otro distinto, con la finalidad de retrasar el ingreso de la deuda tributaria sin pagar el recargo por extemporánea que de otro modo habría correspondido. La consecuencia es que el contribuyente ingresa tardíamente la deuda debida, si bien de hecho se va a beneficiar de lo que sería una financiación implícita a cargo del Tesoro público, de forma gratuita, y generando un evidente daño al erario público. En todo caso, quien así actúa es objeto de una sanción que tiene carácter leve, y que el art. 191.6 LGT limita al 50 por 100 de la cuota. Por tanto, la norma no encierra ninguna discriminación, ya que resulta evidente que no otorga el mismo trato a quien cumple el tipo allí descrito que a quien deja de ingresar la deuda tributaria incurriendo así en un incumplimiento definitivo. No ha quedado así acreditada la homogeneidad de los términos de comparación que se ofrecen, ya que como resulta de la propia lectura del art. 191 LGT, las infracciones graves no tienen un régimen sancionador idéntico al de las leves, de manera que el art. 191.3 y 4 LGT prevé, respectivamente, tipos sancionadores de diferente cuantía, desde el 50 al 100 por 100 en el caso de las infracciones graves; y del 50 a 150 por 100 en el caso de infracciones muy graves. Debe en todo caso recordarse que una eventual actuación arbitraria de la Administración tributaria en modo alguno convierte a la norma legal en arbitraria, siendo precisamente función de los órganos judiciales del orden contencioso-administrativo controlar dicha actuación y, por lo que se refiere en concreto a este supuesto, verificar que se cumple efectivamente el tipo infractor del art. 191.6 LGT y que el art. 25.1 CE ha sido respetado en el plano aplicativo (SSTC 199/2014, de 15 de diciembre, FJ 3; y 218/2005, de 12 de septiembre, FJ 3). Asimismo, debe insistirse una vez más en que la finalidad de la cuestión de inconstitucionalidad no es resolver controversias interpretativas sobre el alcance de determinado precepto legal, cuestión esta extramuros de la jurisdicción constitucional y para la que el ordenamiento jurídico dispone de otros cauces (ATC 255/2013, de 5 de noviembre, FJ 4, con cita de otros muchos).

81 MÁRQUEZ MÁRQUEZ estima posible salvar dicho escollo acudiendo a un interpretación teleológica del ordenamiento jurídico privado, cuyas disposiciones se aplican con carácter supletorio en el Derecho tributario, según dispone el artículo 7.2 de la Ley $58 / 2003, \ldots$, establece como mecanismo valido para la extinción de las deudas la imputación de pagos tácita o silente. Así el Código civil admite, además de la imputación de pagos expresa del artículo 1172, párrafo primero, la tácita o silente, estableciendo reglas concretas para este supuesto en sus artículos 1173 y 1174. MÁRQUEZ MÁRQUEZ,A.:"Comprobaciones inspectoras e imposición de sanciones por la presentación voluntaria de declaraciones-liquidaciones complementarias extemporáneas como medio de regularización fiscal bajo la vigencia de la Ley 230/1963, General Tributaria: el retorno a la responsabilidad objetiva", $Q F$,núm.6, 2008. Esta autor considera al recargo único como sustitutivo de la sanción; En cuanto a retenciones e ingresos a cuenta, continúa pendiente la cuestión de si las mismas son exigibles cuando los sujetos retenidos no se deducen de sus declaraciones personales las retenciones que debieron habérseles practicado, habida cuenta de la inexistencia de perjuicio económico para la Hacienda Pública (salvo el financiero) y del enriquecimiento injusto para la Administración (o doble imposición) que seguramente supondría su exigencia. También aquí existe una suerte de regularización espontánea informal a favor del retenedor, a cargo del sujeto retenido (STS de 13 de noviembre de 1999). BAENA AGUILAR,A.: "Las regularizaciones...op.cit.".JT, núm. 11, 2004, Explica la STSJ de Valencia de 28 de 
autor defiende que se incardinan en este supuesto no sólo el diferimiento de pagos encubierto a través de autoliquidaciones posteriores del infractor ${ }^{82}$, omitiendo así la correcta identificación de la deuda, recargos, intereses y período de que se trata, sino también

abril de $2009\left(\mathrm{FJ}^{\circ}\right)$ «El criterio contrario ha sido sostenido por otros Tribunales Superiores de Justicia y también -esto es determinante para nosotros- por el Tribunal Supremo en su STS de de 14-2-2007, en la cual se excluye la aplicación de la excusa absolutoria de que tratamos, en caso análogo, pues «...la conducta de la sociedad recurrente no ha consistido en la presentación de declaraciones fuera de plazo sin requerimiento previo, sino que, por el contrario todas las declaraciones se presentaron en momento oportuno, pero consignando en ellas e ingresando cantidades inferiores a las que correspondían, cantidades que, sin nueva declaración, ingresaba con la declaración del mes de diciembre, de manera que en dicho mes se ingresaban cantidades superiores a las correspondientes, sin que constase en forma alguna a qué respondía ese ingreso en exceso, siendo la labor inspectora la que hubo de determinar las cantidades que correspondían a cada mensualidad». Por lo tanto no es suficiente con ingresar para aplicar el citado art. 61.3 LGT de 1963, sino que es necesario la realización de una declaración exacta y veraz de la obligación tributaria, lo que aquí no se hubo realizado.»

82 En el art. 191.6 LGT la descripción típica se efectúa sobre determinados incumplimientos formales originados en el momento de la regularización extemporánea, antes de requerimiento administrativo. Es un supuesto en que, en puridad, lo que pretende el legislador es controlar el adecuado cálculo y determinación del recargo automático del art. 27 de la LGT... dicha conducta siempre se considerará como infracción leve, si bien no precisa el dejar ingresar deuda tributaria, ni su ocultación. Pues, como afirma dicho precepto, tal infracción no será aplicable cuando la autoliquidación presentada haya sido previamente objeto de requerimiento. Por consiguiente, la Administración conoce la deuda tributaria por la regularización efectuada, a la cual niega el efecto enervante de la sanción. La conducta infractora no supone un dejar de ingresar, o el efectuar un cálculo incorrecto del recargo, sino el prevenir una hipotética determinación defectuosa. Así, en tal supuesto: 1. Se sanciona una eventual intención, un mero pensamiento no probado de dejar de ingresar el recargo... 2. ${ }^{\circ}$ Se sanciona un comportamiento que no lesiona o pone en peligro bien jurídico alguno. No es una conducta que premie el comportamiento arrepentido del imputado.

Resulta la tipificación de una conducta que adelanta la barrera punitiva a comportamientos inocuos y no probados. Así, se establece la punición de la conducta de un incumplimiento formal que presupone una intención elusoria... La sanción del 50 por 100 a imponer lleva al interrogante de ¿cómo se calculará la base de la sanción cuando no exista cuantía no ingresada?. O sea ¿qué habremos de considerar como cuantía no ingresada?, ¿la deuda tributaria total?, ¿el recargo?. La indeterminación que origina el precepto, junto a la clara lesión de principios básicos punitivos hace que tal infracción resulte inaplicable. Se trata de una infracción formal defectuosamente ubicada, que bascula sobre presunciones de intencionalidad no acreditadas. SÁNCHEZ HUETE, M.A.: "Elementos para un análisis...”, op. cit.págs.181-182. 
cuando, en el caso del artículo 89.Cinco ${ }^{83}$ de la Ley 37/1992 ${ }^{84}$ modificado por la Ley $7 / 2012$, de 29 de octubre, que trata la rectificación ${ }^{85}$ de las cuotas, implique un aumento de las inicialmente reper-

83 La Consulta 161-1998 de la SG de Impuestos sobre el Consumo indica " esta Dirección General considera ajustada a derecho la siguiente contestación a la consulta formulada: 1.- Las entregas efectuadas por la empresa española consultante de medicamentos que se transportan por ella desde el territorio de aplicación del Impuesto sobre el Valor Añadido español a Francia con destino a adquirentes personas físicas que no tienen la condición de empresarios o profesionales no se considerarán realizadas en el territorio de aplicación del Impuesto sobre el Valor Añadido español y no estarán sujetas a dicho tributo cuando se superen los límites de volumen de operaciones establecidos a estos efectos por la legislación francesa (700.000 francos franceses, según datos de marzo de 1996). Tales entregas se entenderán efectuadas en Francia y estarán sujetas al Impuesto sobre el Valor Añadido francés. 2.- En caso de incorrecta repercusión del Impuesto sobre el Valor Añadido español por parte de la empresa consultante por estar las entregas por ella efectuadas, o algunas de ellas, no sujetas a dicho tributo y sí al Impuesto sobre el Valor Añadido francés, deberá dicha empresa rectificar la repercusión efectuada, emitiendo factura rectificativa y pudiendo optar por cualquiera de los dos procedimientos a que se refiere el último párrafo del artículo 89, uno de la Ley 32/1997, esto es: - Iniciar el procedimiento de devolución de ingresos indebidos ante la Administración Tributaria española, en cuyo caso las cuotas indebidamente repercutidas se devolverán por dicha Administración, no a la empresa consultante, sino a los consumidores finales que soportaron indebidamente la repercusión. Esto sólo procederá en los términos contemplados en el Real Decreto 1163/1990 y en particular, en su artículo 9,2 (hoy art. 129 Real Decreto 1065/2007, de 27 de julio, por el que se aprueba el Reglamento General de las actuaciones y los procedimientos de gestión e inspección tributaria y de desarrollo de las normas comunes de los procedimientos de aplicación de los tributos -RGGI-). - Devolver el importe de las cuotas indebidamente repercutidas a los consumidores finales que las soportaron y regularizar la situación tributaria en las declaraciones-liquidaciones que presente ante la Administración española.»

84 Conforme al art. 89.3 ${ }^{\circ}$ LIVA: No obstante lo dispuesto en los apartados anteriores, no procederá la rectificación de las cuotas impositivas repercutidas en los siguientes casos:2. ${ }^{\circ}$ Cuando sea la Administración Tributaria la que ponga de manifiesto, a través de las correspondientes liquidaciones, cuotas impositivas devengadas y no repercutidas mayores que las declaradas por el sujeto pasivo $y$ resulte acreditado, mediante datos objetivos, que dicho sujeto pasivo participaba en un fraude, o que sabía o debía haber sabido, utilizando al efecto una diligencia razonable, que realizaba una operación que formaba parte de un fraude. (así la Consulta 0111/1999 del SG de Impuestos sobre el Consumo).

85 El contribuyente no presentó una declaración de rectificación de las cuotas de IVA, sino que en una declaración posterior incluyó las cuantías de periodos anteriores, por lo que se debe aplicar recargos. Se debe aplicar la sanción contenida en la LGT de 2003, consistente en multa del 50\% de la deuda no ingresada, al ser más favorable al contribuyente que la anterior regulación (SAN, Sala de lo Contencioso-Administrativo, Sec. 6. $\left.{ }^{\mathrm{a}}, 1.7 .2005\right)$. 
cutidas $^{86}$ y no haya mediado requerimiento previo ${ }^{87}$, el sujeto pasivo no haya presentado una declaración-liquidación rectificativa aplicándose a la misma el recargo y los intereses de demora que procedan de conformidad con lo establecido en los artículos 26 y 27 de la Ley General Tributaria. No obstante lo indicado, cuando la rectificación se funde en las causas de modificación de la base imponible establecidas en el artículo 80 LIVA o se deba a un error fundado de dere$\mathrm{cho}^{88}$, el sujeto pasivo podrá incluir la diferencia correspondiente en

86 No se ha vulnerado el principio de especialidad porque «incorrecta repercusión» y "dejar de ingresar» son conceptos distintos (SAN, Sala de lo Contencioso-Administrativo, Sec. 6. ${ }^{\mathrm{a}}, 15.1 .2016$ ).

87 En esas circunstancias, y de acuerdo con lo regulado en el artículo 89, apartado tres, punto segundo) de la Ley 37/1992 y con la reiterada doctrina de este Centro Directivo, hasta que no finalice la actuación inspectora, en la que se determine la conducta tributaria de los mencionados profesionales, no podrá realizarse por parte de los mismos la rectificación de las cuotas no repercutidas (consulta 0738-03 del SG de Impuestos sobre el Consumo). Aunque la entidad consultante consideró correcto el criterio aplicado por la Inspección de los Tributos en cuanto a la procedencia de la repercusión del Impuesto sobre el Valor Añadido, interpuso una reclamación económico-administrativa contra la liquidación inspectora por considerar que el expediente había caducado. La interposición de la citada reclamación tiene como consecuencia, con independencia de cual sea la causa de oposición a la liquidación inspectora, que la deuda tributaria derivada de dicha liquidación queda en suspenso hasta que se resuelva la misma. En consecuencia, la rectificación por la sociedad consultante de la no repercusión en factura de las referidas cuotas no podrá efectuarse hasta que exista resolución o sentencia firme que confirme la liquidación contenida en el acta. El cómputo del plazo de cuatro años a que se refiere el apartado uno, del artículo 89 de la Ley 37/1992 para, en su caso, efectuar la referida rectificación quedará interrumpido desde el inicio de la citada actuación inspectora hasta la finalización, mediante resolución o sentencia firme de la misma (consulta 1202-02, del SG de Impuestos sobre el Consumo). En consecuencia con todo lo anterior, esta Dirección General considera ajustada a derecho la siguiente contestación a la consulta formulada: 1. Habida cuenta de que la conducta de la consultante ha sido calificada por la Administración tributaria como constitutiva de una infracción tributaria, no cabe que aquélla efectúe la rectificación de la repercusión realizadas a un tipo inferior al que correspondía conforme a la normativa reguladora del Impuesto (consulta 1321-97, SG de Impuestos sobre el Consumo).

88 Por ejemplo el de la Consulta 0201-98, del SG de Impuestos sobre el Consumo, cuando considera que, dadas las dudas razonables que han existido en la interpretación de los preceptos que regulaban con anterioridad a 1 de enero de 1998 el tipo impositivo aplicable a las entregas de uva, la rectificación a que se refiere el apartado 1 anterior tiene su causa en un error fundado de derecho, por lo que, de acuerdo con lo dispuesto en el segundo párrafo del apartado cinco del artículo 89 de la Ley 37/1992, la diferencia entre el importe de la cuota del Impuesto resultante de la rectificación de la repercusión inicial que deben efectuar las empresas a que se refiere el escrito de consulta, y el importe de dicha repercusión inicial efectuada por las mismas, deberá hacerse constar por los referidas empresas en la declaraciónliquidación correspondiente al período en que se encuentre el día en que debiesen efectuar la citada rectificación de la repercusión, sin que sean aplicables el recargo y los intereses de demora a que se refiere el artículo 61, número 3 de la Ley General

(C) UNED. Revista de Derecho UNED, núm. 26, 2020 
la declaración-liquidación del periodo en que se deba efectuar la rectificación. Se sostiene que, en el resto de casos de retenciones, no resulta exigible que su realización se efectúe a través de autoliquidaciones rectificativas ${ }^{89}$.

También debemos entender que cabrá regularizar, ex art. 178.5 Real Decreto 1065/2007, de 27 de julio, por el que se aprueba el Reglamento General de las actuaciones y los procedimientos de gestión e inspección tributaria y de desarrollo de las normas comunes de los procedimientos de aplicación de los tributos (RGGI), aquellas obligaciones en las que habiéndose aperturado procedimiento de inspección respecto de determinadas obligaciones tributarias, el órgano competente acuerde, de forma motivada durante el curso del procedimiento por razones que así lo aconsejen, bien la modificación de la extensión de las actuaciones excluyendo alguna obligación tributaria o periodo de los señalados en dicha comunicación -que sería en el que cabría efectuar regularización sin posibilidad de imposición de sanción-, o bien reduciendo el alcance de las actuaciones que se estuvieran desarrollando respecto de las obligaciones tributarias y periodos inicialmente señalados o bien acordando la exclusión de elementos de la obligación tributaria que esté siendo objeto de comprobación en una actuación de alcance parcial.

Dispone el artículo 124.1 de la Ley 27/2014, de 27 de noviembre, del Impuesto sobre Sociedades (LIS) que «la declaración [de este impuesto] se presentará en el plazo de los 25 días naturales siguientes a los seis meses posteriores a la conclusión del periodo im-

Tributaria [1963] si el importe de la referida diferencia se hiciese constar en la citada declaración-liquidación. Los empresarios destinatarios de las operaciones a que se refiere el escrito de consulta estarán obligados a soportar la rectificación al alza de la repercusión que inicialmente les fue realizada por los empresarios que les efectuaron las entregas de uva a que se refiere el apartado 1 anterior, siempre que tal rectificación se ajuste a lo dispuesto en el artículo 89 de la Ley 37/1992 y en el artículo $9^{\circ}$ del Real Decreto 2402/1985, pudiendo a su vez los citados empresarios destinatarios de las operaciones rectificar al alza el importe de la deducción que inicialmente hubiesen practicado, en la declaración-liquidación correspondiente al período impositivo en que reciban las facturas por la que son objeto de rectificación las cuotas que inicialmente les fueron repercutidas, o bien en las declaracionesliquidaciones siguientes, siempre que no hayan transcurrido ninguno de los dos siguientes plazos: a) el plazo de cinco [ahora cuatro] años a contar desde el momento en que se produjo el devengo del Impuesto sobre el Valor Añadido que grava la operación (entrega de uva). b) el plazo de un año a contar desde la fecha en que fue expedida la factura por la que se efectúe la rectificación de la repercusión inicial.

89 El sujeto pretende que el incumplimiento pase desapercibido viéndose libre de recargos que conlleva el incumplimiento ANÍBARRO PÉREZ, S. y SESMA SÁNCHEZ,B.: Infracciones ...op.cit.pág. 118. 
positivo». «Si al inicio del indicado plazo no se hubiera determinado por el Ministro de Hacienda la forma de presentar la declaración de ese período impositivo, la declaración se presentará dentro de los 25 días naturales siguientes a la fecha de entrada en vigor de la norma que determine dicha forma de presentación. No obstante, en tal supuesto el sujeto pasivo podrá optar por presentar la declaración en el plazo al que se refiere el párrafo anterior cumpliendo los requisitos formales que se hubieran establecido para la declaración del período impositivo precedente». Y como es sabido, si el ejercicio económico y, por ende, el período impositivo coinciden con el año natural, esa regla determina que el plazo de autoliquidación y pago del impuesto se extienda, con carácter general, del 1 al 25 del mes de julio (o día hábil siguiente, si aquél no lo fuese). Ahora bien, en los últimos tiempos, y por lo que respecta a ejercicios y períodos impositivos no coincidentes con el año natural, se han planteado situaciones controvertidas en torno a la aplicación de dicha regla, y como consecuencia de ello podría verse perjudicado el principio de seguridad jurídica, que ha de presidir las relaciones entre la Administración (en este caso, la tributaria) y el administrado (a nuestros efectos, el contribuyente).

Por un lado, del manual práctico del Impuesto sobre Sociedades divulgado por la Agencia Estatal de Administración Tributaria (AEAT) se desprendía claramente, en ediciones sucesivas [hasta la del ejercicio de 2004], que para los ejercicios y períodos impositivos no coincidentes con el año natural, el cómputo de los seis meses se haría considerando éstos según el calendario gregoriano, es decir, teniendo en cuenta su configuración en ese calendario (donde a enero le corresponden 31 días; a febrero, 28 o 29, dependiendo de que el año sea o no bisiesto; y así sucesivamente). De acuerdo con dichos manuales, para un período impositivo que finalizase el 30 de junio, el plazo de autoliquidación y pago se extendería del 1 al 25 de 
enero. La Resolución del TEAC de 14 de marzo de $2007^{90}$ corroboraría ese planteamiento ${ }^{91}$.

90 En su Resolución, el TEAC invoca el cómputo administrativo de plazos conforme a la entonces vigente LRJPAC (haciendo valer el carácter supletorio de la misma en el ámbito tributario), y determina (en contra del criterio de la Administración) que para los ejercicios finalizados el 29 de febrero de 2004 y el 28 de febrero de 2005, los plazos de autoliquidación y pago del Impuesto sobre Sociedades concluyeron el 25 de septiembre de 2004 (y el 26 de septiembre de 2005 (ya que el día 25 era domingo), respectivamente: "De lo dispuesto en los preceptos que acaban de citarse [ arts. 7 LGT, 62 LGT, 136 TRLIS, 48 LRJPAC y disposición adicional 5. ${ }^{a}$ LRJPAC] se deduce que dado que en este caso los periodos impositivos concluyeron el último día del mes de febrero de los años 2004 y 2005, el plazo de los «seis meses posteriores a la conclusión del periodo impositivo» que señalaba el art. 136.1 del Real Decreto Legislativo 4/2004, debía comenzar a contarse a partir del 1 de marzo de los respectivos años 2004 y 2005, finalizando el 31 de agosto de dichos años, fecha a partir de la cual, deben a su vez comenzar a contarse los 25 días naturales siguientes a los mencionados seis meses también señalados en el precepto que acaba de citarse, que finalizaron el 25 de septiembre de 2004 y el 26 de septiembre de 2005, ya que el 25 fue domingo, por lo que procede considerar que las autoliquidaciones de que en este caso se trata fueron presentadas en plazo, siendo por tanto improcedente el recargo del 5 por 100 impuesto» .

Reconoce además el TEAC que, habiéndose ajustado la entidad reclamante a los plazos de autoliquidación y pago contemplados por la AEAT, para esos casos, en los manuales prácticos del Impuesto sobre Sociedades, no cabe hablar de extemporaneidad ni, por tanto, aplicar lo dispuesto en el art. 27 LGT (28) .

91 En contra SANZ-DÍAZ PALACIOS para quien, a pesar de la fundamentación normativa de su pronunciamiento en lo que a plazos se refiere, finalmente el TEAC se habría apartado de dicha fundamentación pues ésta llevaría a una solución distinta, que daría la razón a la Administración tributaria. En efecto, si bien la Resolución invoca normativa que implica un cómputo de fecha a fecha (art. 48.2 LRJPAC, precepto que estaría en consonancia con el art. 5.1 CC), en último término, y sin decirlo expresamente, aplica el cómputo natural de los meses, esto es, considerándolos conforme al calendario gregoriano. Con la regla de cómputo de fecha a fecha, tomando como referencia el último día de febrero, esto es, el 28 o 29 de febrero, seis meses se cumplirían el 28 y el 29 de agosto, respectivamente. Contando además 25 días naturales, el plazo de autoliquidación y pago del Impuesto sobre Sociedades finalizaría el 22 de septiembre (en el primer caso) y el 23 de septiembre (en el segundo caso). Sin embargo, con un cómputo por meses naturales (cómputo finalmente aplicado por la Resolución del TEAC que nos ocupa) los seis meses se cumplirían el 31 de agosto, y el Impuesto sobre Sociedades habría autoliquidarse y pagarse entre el 1 y el 25 del mes de septiembre siguiente. En resumidas cuentas, causa sorpresa que el TEAC, invocando la LRJPAC, no califique como extemporáneas las autoliquidaciones presentadas por la entidad recurrente. Si efectivamente hubiese aplicado el art. 48.2 LRJPAC [hoy art.30.4.in fine LPACAP], se habría visto en la necesidad de reafirmar el criterio de la Administración (Delegación Central de Grandes Contribuyentes). A nuestro juicio, que la entidad reclamante siguiera el criterio de plazos expresado en los manuales prácticos de la AEAT constituye la razón principal de que el TEAC estime las reclamaciones y, por tanto, anule los recargos por autoliquidación extemporánea exigidos... A modo de conclusión, y en todo caso a la luz de nuestra jurisprudencia, podemos afirmar que no habría acertado el TEAC en su resolución del año 2007, al aplicar, en puridad, un cómputo por meses naturales (y ello a pesar de la argumentación 
Por otro lado, el 5 de octubre de 2009, respondiendo a una consulta que se le había formulado, la Dirección General de Tributos (Consulta V2197/200992) establece un criterio distinto, a saber, que en el supuesto concreto de referencia (períodos impositivos que finalicen el 30 de junio), «el plazo de 25 días empezaría a computar el día siguiente al 30 de diciembre, esto es, el 31 de diciembre, concluyendo, al ser días naturales, el 24 de enero del año siguiente». Con posterioridad, la SAN de 13 de junio de 2011, ha confirmado el criterio de la Dirección General, si bien se posiciona a favor de la entidad recurrente, considerando que ésta se ajusta a la interpretación difundida por la AEAT en sus manuales prácticos y que dicha entidad realiza, por tanto, una interpretación razonable de la norma ${ }^{93}$ ( art. 136.1 Real Decreto Legislativo 4/2004, de 5 de marzo, por el que se aprueba el texto refundido de la Ley del Impuesto sobre Sociedades- TRLIS- , hoy art. 124.1 Ley 27/2014, de 27 de noviembre, del Impuesto sobre Sociedades -LIS), al entender que el 25 de enero es el último día del plazo para autoliquidar y pagar el Impuesto sobre Sociedades de un ejercicio que termina el 30 de junio. Otros órganos jurisdiccionales han aplicado el mismo criterio que la DGT. Es el

jurídica que fundamenta esa resolución). Se ha de aceptar, pues, el criterio sentado por la DGT en 2009, criterio que asume la SAN de 13 de junio de 2011, donde se satisface la pretensión de la recurrente, si bien invocando para ello los principios de seguridad jurídica y de confianza legítima, a la vista del error en el que, como queda expuesto, habrían incurrido los manuales prácticos de la AEAT. Ciertamente, en aras del principio de seguridad jurídica, la regla del cómputo de los seis meses previstos en el art. 136.1 TRLIS debe aplicarse de modo unívoco y preciso. A nuestro parecer, la confusión creada en los últimos tiempos aconseja una labor clarificadora (a la que pretendemos contribuir con este trabajo), para que ningún obligado tributario llegue a abrigar dudas en cuanto al período de autoliquidación y pago del Impuesto sobre Sociedades. A esos efectos, no parece necesario plantear una hipotética modificación en la literalidad de dicho precepto. SANZ DÍAZPALACIOS,J.A.: "Seguridad jurídica, confianza legítima y plazo de autoliquidación e ingreso del Impuesto sobre Sociedades (Disparidad de posicionamientos en sede administrativo-tributaria y jurisdiccional)", Diario La Ley, núm. 8020, Sección Tribuna, 11 Feb. 2013.

92 La resolución del TEAC de 14 de marzo de 2007 habría determinado el período de autoliquidación y pago del Impuesto sobre Sociedades, computando para ello meses naturales, y sin embargo, en la consulta que nos ocupa, la DGT dispone que los meses se computen de fecha a fecha. Como vemos, se da una disparidad de criterios y, por tanto, de soluciones. Considerando meses naturales, el plazo para autoliquidar y pagar el Impuesto sobre Sociedades en el supuesto al que se refiere la consulta abarcaría del 1 al 25 de enero del año posterior (o día hábil siguiente, si aquél no lo fuese).

93 En otro supuesto, se valoré que el contribuyente no haya probado que la falta de ingreso tuviera su origen en el complejo régimen de retenciones por rendimientos de capital mobiliario (SAN, Sala de lo Contencioso-Administrativo, Sec. 4. $\left.{ }^{\mathrm{a}}, 11.3 .2009\right)$. 
caso del TSJ Andalucía ${ }^{94}$, del de Castilla y León ${ }^{95}$, o del de la región de Murcia ${ }^{96}$. También es el caso del TSJ de Galicia ${ }^{97}$, en un pronunciamiento anterior, incluso, al citado de la AN. En definitiva, la AN asume la solución dada por la DGT en 2009, esto es, admite el cómputo de fecha a fecha. Se rechazaría, pues, el criterio del TEAC en su Resolución de 2007, es decir, descartaría el cómputo por meses naturales.

\subsection{Infracción por incumplimiento de la obligación de retener, de efectuar pagos a cuenta o fraccionados}

El art. 191 de la LGT (2003), al igual que sucedía durante la vigencia de la antigua LGT $^{98}(1963)$, parece confirmar la autonomía de la obligación de retener, al disponer el establecimiento de una sanción para aquellas conductas infractoras consistentes en la falta de ingresos tributarios repercutidos o de las cantidades retenidas o que

94 Sentencia de 15 de julio de 2011 (rec. 1496/2008, Sala de lo ContenciosoAdministrativo).

95 Sentencia de 26 de marzo de 2012 (rec. 1128/2007, Sala de lo ContenciosoAdministrativo).

96 Sentencia de 30 de noviembre de 2011 (rec. 1330/2008, Sala de lo Contencioso-Administrativo).

97 STSJ Galicia de 8 de febrero de 2010 (rec. 15519/2008, Sala de lo Contencioso-Administrativo).

98 Hasta ese momento cabía la posibilidad de que un determinado contribuyente dedujese en su autoliquidación unas retenciones que no hubiesen sido efectivamente ingresadas por el obligado a hacerlo, de manera que la Administración no pueda hacer efectivo su importe, al prescribir por ejemplo su derecho frente al retenedor o por insolvencia de éste. En esta línea se situaban además, entre otras, las Resoluciones del TEAC de 25 de septiembre de 1996, 23 de junio y 7 de noviembre de 1997 y de 8 de septiembre y 22 de diciembre de 2000 y de 19 de abril de 2007, STSJ de Castilla y León de 13 de octubre de 2001, así como las SsTSJ de Asturias de 24 de febrero y de 13 de abril de 2000 y la SAN de 7 de noviembre de 2002. En todas ellas se señalaba que «la obligación de retener e ingresar es autónoma y no está en función de si el retenido deduce o no en su autoliquidación lo que debió retenerse por el pagador». 
se hubieran debido retener ${ }^{99}$ o ingresar a cuenta ${ }^{100}$ de cualquier impuesto, no quedando condicionada la imposición de dicha sanción al hecho de no haberse ingresado ${ }^{101}$ por el contribuyente, que es el obligado último a soportar la retención de la cantidad que no le fue retenida. Siguiendo a la STS de 27 de febrero de $2007^{102}$, con la fina-

99 En relación al art. 79.a) LGT, entendía PÉREZ ROYO que hubiera sido [al tratar la LGT 1963] más adecuado un tratamiento diferenciado del supuesto relativo a la falta de ingreso de las retenciones que debieron practicarse respecto de aquel otro referido a la falta de ingreso de las efectivamente practicadas, pues estas últimas no sólo constituían infracciones graves, sino que integraban el tipo delictivo de apropiación indebida, sin que para su existencia sea necesaria la concurrencia del tope cuantitativo del CP. PÉREZ ROYO,F.: Los delitos...op.cit. pág. 325. El TEAR anuló la liquidación del IRPF al entender que la liquidación de retenciones practicada a la empleadora se ha efectuado sin examinar cómo cada uno de los retenidos ha llevado a cabo el cumplimiento de su obligación tributaria. Se desconoce si la Administración se vio perjudicada por existir un ingreso inferior al correspondiente, por lo que es contradictorio el mantenimiento de la sanción al carecer del presupuesto de hecho que la sustenta (STSJ Madrid, Sala de lo Contencioso-Administrativo, Sec. 5. $\left.{ }^{\mathrm{a}}, 11.10 .2012\right)$. Aunque, el cumplimiento de la obligación por parte de los trabajadores afectados imposibilita exigir la cuota de la retención a la recurrente, ello no impide aplicarle la sanción prevista por no retener (STSJ Andalucía, Sevilla, Sala de lo Contencioso-Administrativo, Sec. 2. $\left.{ }^{a}, 13.7 .2012\right)$. No cabe exigir las cantidades esperadas y dejadas de ingresar mediante retención sin antes comprobar lo declarado por el retenido. Si se anuló la liquidación por no haberse hecho la comprobación previamente, la sanción es improcedente al no conocerse la base para su cálculo (SAN, Sala de lo ContenciosoAdministrativo, Sec. 4. $\left.{ }^{\mathrm{a}}, 28.12 .2011\right)$.

100 El legislador diferencia entre las retribuciones pecuniarias, a las cuales les aplica una retención, y las retribuciones no pecuniarias o en especie, para las cuales el calificativo de retención no es gramaticalmente correcto, porque al no haber numerario, no hay referencia sobre la cual retener un porcentaje también numerario. Es por ello que, al no poder emplear la palabra retención, se emplea la palabra ingreso o pago a cuenta. MUÑ́́Z BAÑOS, C.: Infracciones tributarias y delitos contra la Hacienda Pública, Edersa, Madrid, 1996,pág.154.

101 El recurrente no ha acreditado el pago de los servicios cuyas facturas contenían las retenciones por lo que ahora no puede reclamar a la Administración la devolución de las retenciones que constan en la factura. Es procedente la sanción porque concurre el requisito de la culpabilidad cuando el recurrente trata de sobre retenciones de facturas que no ha acreditado haber cobrado (STSJ Madrid, Sala de lo Contencioso-Administrativo, Sec. 5. $\left.{ }^{\mathrm{a}}, 11.5 .2017\right)$.

102 En igual sentido la Resolución del TEAC de 3 de abril de 2008 y la STS de 5 de marzo de 2008, afirma que no cabe regularizar las retenciones no practicadas con desconexión del cumplimiento de la obligación tributaria principal por parte del sujeto pasivo. En opinión del Tribunal, «debe superarse aquella doctrina que asume la naturaleza independiente o autónoma de la obligación del retenedor sin tomar en consideración la conducta del contribuyente, que constituye el auténtico obligado al pago de la obligación tributaria principal». Nótese por tanto como el TS viene a modificar la doctrina que asumía la naturaleza independiente o autónoma de la obligación del retenedor, estableciendo que la Administración tributaria no puede exigir a aquél las cantidades que debían haber sido retenidas e ingresadas si, en el momento en el que se efectúa la regularización administrativa, ya se ha extinguido la obligación tributaria principal. Se estima así que si la entidad 
lidad de evitar un enriquecimiento injusto a la Administración, se impide la exigencia al retenedor de las retenciones no aplicadas en aquellos casos en los que se haya producido ya una regularización por parte del perceptor de las rentas en su declaración anual. Ahora bien, tal y como se encarga de precisar el propio Tribunal, «ello no impide que la Administración pueda exigir del retenedor ${ }^{103}$ los efec-

retenedora hubiese declarado correctamente el importe total de las retribuciones de trabajo personal aplicando a éstas los tipos porcentuales de la tabla de retenciones, y si todos los empleados de la entidad hubieran declarado de manera veraz, por su parte, a efectos de su IRPF, sus retribuciones de carácter personal, habría que concluir que respecto de todas estas retribuciones han satisfecho el impuesto correspondiente $\mathrm{y}$, por lo tanto, la exigencia posterior a la entidad retenedora de cuotas adicionales por retenciones supondría la existencia de una doble imposición. CALVO VÉRGEZ,J.: "Una aproximación a la naturaleza jurídica de la retención en el IRPF”, Aranzadi Doctrinal,núm.1,2009.

103 Regularizada por la Administración la situación tributaria de un obligado a retener, que no ha practicado las retenciones a que estaba obligado, o las practicado por un importe inferior al debido, y no resultando exigible el pago de la liquidación, pues la exigencia de este pago da lugar, o puede dar lugar, a un enriquecimiento injusto de la Administración (como consecuencia de la conducta de otro obligado tributario distinto, el perceptor de los rendimientos sujetos a retención, al presentar éste las autoliquidaciones correspondientes a su imposición personal sin deducirse las retenciones que debieron serle practicadas), no procede anular automáticamente la sanción que deriva de esa regularización al retenedor, sino que, por el contrario, puede mantenerse esa sanción, siempre que concurran los demás elementos precisos para ello, en particular la acreditación del elemento subjetivo de la culpabilidad del obligado a practicar la retención. La infracción cometida es la tipificada en el artículo 191.1 de la Ley 58/2003 General tributaria, siendo la base de la sanción (de conformidad con el artículo 8 del Real Decreto 2063/2004 por el que se regular el Reglamento sancionador) la cantidad a ingresar que en su momento debió consignarse en la autoliquidación por retenciones que debió presentar el obligado a retener, cantidad que ha sido determinada por la Administración en la regularización llevada a cabo (RTEAC Unificación de criterio 26.6.2012). Existe una contradicción entre la doctrina de este Tribunal Supremo plasmada en la sentencia de 19 de julio de 2017 [RCA/2565/2016 (ES:TSJAND:2017:2290 )] que permite la regularización de los intereses sobre las cantidades que se debieron retener, pero impide exigir las cuotas dos veces para no generar enriquecimiento injusto, si bien permitiendo la imposición de sanciones, y las sentencias de 28 de junio de 2013 [RCA/3247/2010 (ES:ECLI:ES:TS:2013:3971 )] y 2 de octubre de 2008 [RCA/207/2006 (incorrectamente citada)], la cual requeriría una aclaración. Al mismo tiempo, existe una jurisprudencia recogida en sentencias del Tribunal Supremo de 28 de junio de 2013 [RCA/3247/2010 (ES:ECLI:ES:TS:2013:3971 )] y 2 de octubre de 2008 [RCA/207/2006] que consideran que, una vez prescrita la obligación principal, no es posible regularización alguna referente a su accesoria. Según la sentencia recurrida, en ese conflicto, al menos aparente, entre ambos criterios, prima el de la sentencia de 19 de julio de 2017 , de modo que le es lícito a la Administración sancionar y liquidar intereses aunque se hubiera extinguido la obligación principal por prescripción. El recurrente sostiene que queda vulnerado el principio de tipicidad (del artículo 8 del Real Decreto 2063/2004, de 15 de octubre en relación al art. 191.4 LGT) al exigirse una sanción por dejar de ingresar cuando la cuota regularizada es cero euros, que se calcula en un porcentaje sobre 
tos perjudiciales que para ella se hayan producido por el hecho de no haberse practicado o de haberse practicado mal dichas retenciones», en clara alusión a los intereses y a las sanciones que el retenedor pueda merecer». A juicio del Tribunal Supremo, para poder admitir una eventual exigencia administrativa de las retenciones al retenedor se impone a la Administración la carga de la prueba de

la deuda dejada de ingresar, destacando que no existe jurisprudencia del Tribunal Supremo al respecto. Al respecto expresa el ATS núm. 4752/2019 de treinta de abril de 2019 que "son dos las cuestiones que suscita este recurso de casación, según la exposición de la recurrente: 1. Precisar si puede la Administración tributaria liquidar la obligación accesoria de pago de intereses de demora -cuando la empresa incumplió su deber legal de practicar retenciones e ingresar a cuenta del IRPF-, en aquellos casos en que se ha extinguido la obligación principal de pago, por prescripción, del que aquélla es accesoria. 2. Determinar si es posible sancionar al retenedor que no ha ingresado las retenciones a cuenta del IRPF cuando la cuota de la liquidación girada por la Administración en concepto de retenciones es cero; y, a tal fin, establecer a los efectos punitivos del artículo 191 LGT cuál es la base de la sanción cuando la cuota de la liquidación girada es cero. 2. A juicio de esta Sección de Admisión, es indudable el interés casacional objetivo para formar jurisprudencia que presentan tales dos cuestiones. La relativa a la posibilidad de liquidar intereses de demora por el retraso en el cumplimiento de la obligación accesoria de retener e ingresar lo retenido, tras haber prescrito el derecho a liquidar la obligación principal, presenta ese interés casacional objetivo para formar nueva doctrina. Así, ni la sentencia de este Tribunal Supremo de 19 de julio de 2017 ni la de 28 de junio de 2013 abordan directamente esta cuestión, por lo que, así enunciada, presenta interés casacional objetivo para la formación de jurisprudencia porque la norma que sustenta la razón de decidir de la sentencia discutida no ha sido nunca interpretada por este Tribunal Supremo para una situación de hecho como la contemplada en este litigio [ artículo 88.3.a) LJCA ], por lo que resulta conveniente un pronunciamiento judicial que las esclarezca, aclare y complete nuestra jurisprudencia. 3. Igual interés casacional concurre en la cuestión relativa a si es posible sancionar al retenedor que no ha ingresado las retenciones a cuenta del IRPF, cuando la cuota respectiva girada es de cero euros, lo que conlleva, en su caso, la precisión de cuál sería la base de la sanción en este caso. Esta cuestión presenta evidente interés casacional objetivo para la formación de jurisprudencia, bastando a tal efecto la presunción del artículo 88.3.a) LJCA , siendo conveniente un pronunciamiento de este Tribunal Supremo que la esclarezca, cumpliendo su función uniformadora, y sirva como criterio orientador de los tribunales inferiores, así como pacificador de la situación controvertida, interés que, podemos anticipar, reside en la adecuación o no de la potestad sancionadora al principio de tipicidad, tanto en la enunciación de la infracción, consistente en dejar de ingresar ( nullum crimen sine lege ), como en la determinación legal de la sanción, cuya tipificación se manifiesta en una multa pecuniaria proporcional a la suma dejada de ingresar (nulla poena sine lege ). En cambio, no apreciamos que quede comprometido el principio de proporcionalidad -es de suponer que quebrantado en la sentencia, no en la ley que tipifica la infracción y la sanción ni en el ejercicio de la potestad sancionadora por parte de la Administración tributaria, pues tal principio presupone ineluctable la posibilidad misma de sancionar y el deber de hacerlo ateniéndose a determinados límites objetivos, lo que no sucedería, por incompatibilidad lógica, si llegamos a la conclusión de que es la potestad misma la que no podría ejercitarse por falta de su misma base legal."

(C) UNED. Revista de Derecho UNED, núm. 26, 2020 
que ese doble pago no se ha producido, no considerándose como válida una mera actuación pasiva de aquélla en virtud de la cual se limite únicamente a considerar que ese doble pago o cobro no se ha producido, evitando el enriquecimiento injusto de la Administración ${ }^{104}$, así podrían continuar exigiéndose al pagador cuotas no retenidas en aquellos casos en los que el retenido hubiese descontado en su declaración de IRPF la retención correcta que realmente no soportó o incluso cuando, con motivo de una liquidación practicada al perceptor la Administración le hubiese computado dicha retención como procedente. Concluye pues el Tribunal Supremo que la Administración tributaria no debe practicar liquidación alguna al retenedor como consecuencia de unas retenciones no practicadas cuando el perceptor de los rendimientos ha pagado una cuota de IRPF superior al no haber deducido la citada retención.

Respecto de las retenciones que norma el artículo 191.4 de la LGT, algunos autores ${ }^{105}$, ya con la anterior LGT, consideraban que hubiera sido conveniente diferenciar dos supuestos: por un lado, el de las retenciones practicadas y que no se han ingresado y, por otro lado, las retenciones que no se han practicado y por lo tanto no han sido ingresadas ${ }^{106}$. Esta distinción tiene su razón de ser en el hecho

104 Así sucedería, por ejemplo, en aquellos casos de trabajadores que no han presentado declaración del IRPF por el ejercicio en cuestión, ya sea porque la cuantía de las retribuciones brutas del trabajo percibidas individualmente por cada uno de ellos no supere el límite de la obligación de declarar o porque, dada la cuantía de las retribuciones percibidas y de las retenciones soportadas (inferiores a las que resultasen procedentes), y teniendo en cuenta su situación personal y familiar, habiendo presentado declaración resultase una cuota a ingresar.

105 Son varios los autores para los que hubiera sido preferible diferenciar los dos supuestos: PÉREZ ROYO, F.: Los delitos...op.cit., págs. 325 y 326; QUEROL GARCIA,M.T.: Régimen de infracciones y sanciones tributarias, Deusto, Bilbao, 1991, pág. 97; AGUALLO AVILÉS, A.: "Infracciones", en la obra colectiva Comentarios a la LGT y lineas para su reforma, Vol.II. IEF, 1991, pág. 1.170; MERINO JARA, I. y SERRANO GONZÁLEZ DE MURILLO, J.L.: "La elusión del pago de cantidades a cuenta de tributos y la proyectada reforma de los delitos contra la Hacienda Pública”, Civitas REDF, núm. 86, 1995, págs. 287 y ss; MARTÍNEZ LAGO, M.A.;APARICIO PÉREZ,J.;BAENA AGUILAR,A. y GARCÍA DE LA MORA,L.: Código de delitos e infracciones en materia financiera y tributaria, La Ley, Madrid, 1993, págs. 427 y 428; en la conducta de quien retiene y no ingresa se denota más malicia. ALBIÑANA GARCÍA-QUINTANA, C.: "Tipificación de las infracciones tributarias", RJE, III,1986, pág. 846; RUÍZ GONZÁLEZ, R..J.: "El nuevo régimen de infracciones y sanciones tras la modificación de la Ley General Tributaria (II)", Carta Tributaria, Monografías, núm. 235, 1995, pág. 6.

106 La interesada sí efectuó las retenciones, aunque no en la cuantía que las liquidaciones practicadas señalaban, por lo que para sancionar se requiere un especial esfuerzo en orden a la motivación de la culpabilidad del infractor (STSJ Murcia, Sala de lo Contencioso-Administrativo, Sec. 2. $\left.{ }^{a}, 29.1 .2016\right)$. Se anula la sanción al ingresar fuera de plazo la Retención de Arrendamientos inmuebles, 
de que el primer caso, que constituye una conducta más peligrosa, podría constituir un delito penal de apropiación indebida por parte del retenedor, aunque tras la reforma del CP de 1995, hay que tener en cuenta sin embargo que aquellas conductas consistentes en el no ingreso de los tributos repercutidos, las retenciones practicadas y los ingresos a cuenta practicados ${ }^{107} \mathrm{en}$ las que se obtiene «un lucro indebido o enriquecimiento injusto» ${ }^{108}$, existe una cierta "apropiación indebida» pero sin que pueda aplicarse tal calificación sino la del delito fiscal del art. 305 CP.

porque la interesada ha presentado certificado de exoneración de rentas de la entidad de la que era arrendataria, por lo que se presume la buena fe (STSJ Cataluña, Sala de lo Contencioso-Administrativo, Sec. 1. a , 20.6.2013).

107 La omisión del ingreso de pagos fraccionados o a cuenta no ocasionará perjuicio de ningún tipo para la Hacienda si en la posterior liquidación se ingresa la totalidad de la deuda, con lo que la auténtica sustracción de ingresos, el auténtico perjuicio, se producirá en todo caso con la omisión del ingreso definitivo, no siendo sancionable por este tipo.... De igual modo, la omisión del ingreso de los pagos fraccionados no podrá ser objeto de sanción independiente en el caso de que vaya seguida de la falta de ingreso de la deuda tributaria definitiva (obligación tributaria principal), pues difícilmente podría admitirse dicha sanción cuando el perjuicio económico no llega a producirse al efectuarse el ingreso de la deuda pese a la inicial omisión de los pagos fraccionados o a cuenta- de otro modo se estaría sancionando dos veces-. En efecto... los ingresos realizados fuera de plazo a que el pago de la deuda (principal) equivale, respecto de los pagos fraccionados omitidos a un ingreso extemporáneo que libera al sujeto de la responsabilidad por infracciones, sin perjuicio de la aplicación de los intereses de demora que puedan corresponder. ZORNOZA PÉREZ,J.J.:El sistema...op.cit. pág. 240 a 242; El RD 1793/2008 incorpora un nuevo apartado 7 al artículo 62 del Reglamento del Impuesto sobre Sociedades [en la actualidad se corresponde con el art.64.7 del Real Decreto 634/2015, de 10 de julio, por el que se aprueba el Reglamento del Impuesto sobre Sociedades], en virtud del cual cuando la obligación de retener o ingresar a cuenta tenga su origen en el ajuste secundario realizado, la base de la retención o ingreso a cuenta será la diferencia entre el valor convenido y el valor de mercado. Resulta criticable el que haya sido un mero Reglamento el que haya introducido la obligación de retener en las rentas recalificadas fiscalmente. En la Ley 36/2006 antifraude no se establecía expresamente el deber de practicar tal pago a cuenta, con lo que se aprecia un claro motivo de impugnación por vulneración del principio de legalidad tributaria. MARTÍNEZ-CARRASCO PIGNATELLI,J.M.:"El ajuste secundario en la Ley y Reglamento del Impuesto sobre Sociedades (A propósito del RD 1793/2008, de 3 de noviembre)",QF, núm. 12/2009.

108 La liquidación impugnada detalla los perceptores de rendimientos con discrepancias y las retenciones calculadas por la Agencia Tributaria con referencia al modelo 190, por lo que no existe indefensión. La actuación de la Administración exigiendo la retención al retenedor cuando ya ha sido pagada por los sujetos pasivos la cuota correspondiente a su deuda tributaria implica una doble imposición. Procede anular la resolución recurrida, pues la anulación de la liquidación provisional impide sancionar al no existir la deuda tributaria que constituye la infracción (STSJ Madrid, Sala de lo Contencioso-Administrativo, Sec. 5. a , 4.6.2013). 
El incumplimiento de ingresar pagos a cuenta, en la vía administrativa, no constituye infracción tributaria, pese a estar correctamente sancionado ${ }^{109}$, sin embargo, dicho incumplimiento sí es susceptible de constituir delito contra la Hacienda Pública, cuando el retenedor haya incurrido en dolo y la cuota defraudada supere los $120.000 €$, pues el tipo del artículo 305 del Código Penal incluye tanto los tributos como las cantidades retenidas o que se hubieran debido retener o ingresos a cuenta de retribuciones en especie. Las deficiencias técnicas de las leyes tributarias, especialmente las de carácter sancionador, no deben perjudicar al contribuyente, máxime si aplicamos la doctrina del Tribunal Constitucional que en innumerables Sentencias — STC 18/1981, por todas - ha afirmado que "los principios inspiradores del orden penal son de aplicación, con ciertos matices, al Derecho Administrativo sancionador, dado que ambos son manifestaciones del ordenamiento punitivo del Estado». El papel fundamental de estos principios, con independencia de su carácter informador del Ordenamiento jurídico, es delimitar la potestad sancionadora de la Administración, salvaguardando los derechos fundamentales de los contribuyentes.

109 La «inexistente» infracción por dejar de ingresar pagos a cuenta presenta, en su calificación, las siguientes deficiencias técnicas: 1. Calificar una infracción de grave o muy grave en función de un porcentaje presupone admitir el error de salto vulnerando con ello el principio de proporcionalidad. Así, por ejemplo, un contribuyente que hubiera dejado de ingresar retenciones por importe de 6.000€, si las practicadas y no ingresadas ascienden a $3.000 €$, la infracción se califica de grave, con multa pecuniaria proporcional del 50 al 100 por ciento; pero si las practicadas y no ingresadas ascienden a $3.001 €$, la infracción deviene en muy grave con multa pecuniaria proporcional del 100 al 150 por ciento, es decir, $1 €$ de más en el numerador duplica la sanción. 2. La utilización de medios fraudulentos, que en todo caso determina que la infracción por dejar de ingresar pagos a cuenta se califique de muy grave, retorna a técnicas liquidadoras propias de los tributos. Nos referimos a los artículos 11 (cálculo de la incidencia de la llevanza incorrecta de libros o registros) y 12 (cálculo de la incidencia de la utilización de facturas, justificantes o documentos falsos o falseados) del Real Decreto 2063/2004 que aprueba el Reglamento general del régimen sancionador tributario. El artículo 191 de la Ley 58/2003, en su apartado 1, tipifica la infracción por dejar de ingresar la deuda tributaria que debiera resultar de una autoliquidación y en sus apartados 2, 3 y 4 establece los criterios para calificar dicha infracción como leve, grave o muy grave, especificando la pertinente sanción, en el entendimiento de que esta infracción nunca será leve "cuando se hayan dejado de ingresar cantidades retenidas o que se hubieran debido retener o ingresar». DELGADO SANCHO,C.D.: "La infracción por dejar de ingresar pagos a cuenta", Impuestos, núm. 22, Sección Doctrina, Quincena del 16 al 30 Nov. 2009, Año XXV, Ref. D-626, pág. 309, tomo II, Editorial LA LEY. 
La cuestión de los pagos fraccionados ${ }^{110}$ demandaría que se aclarase un poco más su contenido. En efecto, una persona que no realiza los pagos fraccionados (art. 23.1 LGT) dentro de los plazos que tiene establecidos para hacerlo, es evidente que si luego no se los deduce ${ }^{111}$ cuando presenta la declaración final o recapitulativa de todo el período, significa que los está ingresando en ese momento, en tanto en cuanto no se los está deduciendo. Se trataría, a nuestro juicio $^{112}$, de un ingreso extemporáneo realizado sin requerimiento previo, al que debe aplicársele el recargo del artículo 27 de la LGT.

\subsection{Obtención de devolución tributaria solicitada indebidamente}

El artículo 191.5 LGT incluye como tipo el que el obligado presente una autoliquidación en la que solicite indebidamente una devolución y la obtenga (supuesto típico del artículo 193 de la LGT), cuando en realidad debería haber efectuado un ingreso, concurriendo dos conductas, dejar de ingresar y obtener indebidamente devoluciones, optando el legislador por subsumir la infracción consistente en obtener indebidamente devoluciones en la infracción consistente en dejar de ingresar en plazo la deuda que debiera haber resultado de la autoliquidación, otorgándoles un tratamiento único. Así las cosas, no se sancionará en este caso la infracción consistente en la obtención indebida de una devolución- no habrá dos infracciones independientes, sino una, la del art. 191.5 LGT, por el resultado de adicionar al importe de la devolución obtenida indebidamente la cuantía que hu-

110 Procede la anulación de la sanción, máxime cuando la obligada tributaria se limitó en este caso a seguir aplicando el criterio de cálculo de los pagos fraccionados que vino empleando durante muchos años antes (STSJ Castilla y León, Valladolid, Sala de lo Contencioso-Administrativo, Sec. 1. a , 15.9.2015).

111 La Oficina Gestora puede practicar liquidaciones cuando al examinar la documentación aportada comprueba que no se acreditan los supuestos que justifican el carácter deducible de los gastos. Es correcta la imputación a existencias finales de todas las facturas emitidas con posterioridad a la venta del único chalet enajenado. Respecto a la deducibilidad del leasing es necesario que el esté registrado en el Libro de bienes de inversión. Procede la imposición de la sanción, porque los interesados no actuaron con la diligencia debida en la deducción improcedente de gastos de la actividad económica, apreciándose falta de la diligencia debida (S TSJ Castilla y León, Burgos, Sala de lo ContenciosoAdministrativo, Sec. 2. ${ }^{\mathrm{a}}$, 24.7.2015).

112 MUÑÓZ BAÑOS,C.: Infracciones...op.cit.,págs.155,209 y 210; Este autor cita, a favor de su tesis, el Informe de la Subdirección General de Ordenación Legal y Asistencia Jurídica de la AEAT de 15 de abril de 1996.

(C) UNED. Revista de Derecho UNED, núm. 26, 2020 
biera debido ingresarse en la autoliquidación ${ }^{113}$-, y el plazo de prescripción se computará desde que finalizó el plazo voluntario para ingresar la cantidad que correspondiere mediante autoliquidación ${ }^{114}$.

\subsection{La regularización tributaria encubierta}

Se regula en el apartado $6^{115} \mathrm{del}$ artículo 191 LGT la «regularización voluntaria encubierta» ${ }^{116}$ por no cumplirse alguno de estos dos

113 AA.VV. (Coord. PELÁEZ MARTOS, J.Mª): Todo procedimiento..op.cit.págs. 1068-1069.

114 Esta formulación se hace eco de la generalización de la gestión a través de la autoliquidación, puesto que en algún caso media un tiempo considerable desde el devengo hasta el plazo de declaración, durante ese lapso no puede la Administración ni liquidar ni exigir la deuda, siendo incoherente que contara ya para la prescripción. COLLADO YURRITA, M.A.(Dir.); LUCHENA MOZO,G.M.(coord.), et alii: Derecho Tributario. Parte General, Atelier, Barcelona, 2007, pág. 236; En este caso, se entiende que la cuantía no ingresada es la suma de la devolución más lo que hubiera debido ingresarse en la autoliquidación. Por este motivo, la devolución obtenida indebidamente no es sancionable, de forma aislada y de acuerdo con el art. 193.5. La infracción de falta de ingreso absorbe la de obtener devoluciones improcedentemente. RUÍZ GARIJO,M.: "Infracciones y sanciones tributarias: régimen transitorio tras la entrada en vigor de la nueva LGT",QF, núm. 4, 2005.

115 PALAO no se muestra conforme con la solución legislativa dada a este problema. A su juicio, el comportamiento del sujeto no es merecedor del mismo reproche que aquel que no ingresa y no manifiesta ningún arrepentimiento o deseo de regularizar su situación.....No considera que este precepto sea muy respetuoso con el principio de proporcionalidad de las penas. PALAO TABOADA, C.: Comentario sistemático a la nueva Ley General Tributaria, CEF, Madrid, 2004, pág.555. La base de la sanción correspondiente a la infracción tributaria regulada en el artículo 191 de la Ley 58/2003, de 17 de diciembre, General Tributaria será, en todo caso, la cuantía no ingresada en la autoliquidación como consecuencia de la comisión de la infracción. Ello incluso en los supuestos que se corresponden con las conductas descritas en el artículo 191.6 primer párrafo de la Ley General Tributaria, sin perjuicio de que dichas conductas queden tipificadas como infracción tributaria leve (RTEAC 8.9.2016).

116 Así el momento de la comisión de la infracción se entiende producido cuando, transcurrido el plazo, no se ha ingresado total o parcialmente la deuda. El hecho de que, por sucesivas autoliquidaciones sin requerimiento posteriores, se vaya ingresando parcialmente lo que se dejó de ingresar dentro del plazo, no hace que la infracción se desplace hacia el momento en que se realizan esos ingresos parciales y se entienda que es en ellos cuando se vuelve a dejar de ingresar. Lo que aún no se ha ingresado, a pesar de las regularizaciones parciales, no se ha ingresado dentro del plazo originario de presentación, no se ha dejado de ingresar ahora. LAMOCA PÉREZ,C.: Infracciones...op.cit.págs.215 y 216; Si bien existe ingreso extemporáneo, falta la identificación correcta del período al que se refiere. MESTRE GARCÍA, E. y CERVANTES SÁNCHEZ-RODRIGO, C. J.: Guía de infracciones...op.cit., pág.139; Esta misma interpretación ya la venía manteniendo con anterioridad el TEAC, señalando que para excluir las sanciones, el contribuyente no sólo debía ingresar, sino que además debía regularizar su 
requisitos, que se identifique expresamente el período impositivo de la liquidación a que se refiere y que contenga únicamente los datos relativos a ese período, ya que si se dan los requisitos ${ }^{117}$ no existiría infracción ${ }^{118}$ sino recargo por declaración ${ }^{119} \mathrm{o}$ autoliquidación extem-

situación tributaria presentando la correspondiente declaración-liquidación o autoliquidación omitida o bien una complementaria rectificando otra anterior formulada en plazo, en las que se indicase el período a que corresponden las bases y cuotas que son objeto de regularización. Por último, la regularización de las devoluciones indebidamente obtenidas por el obligado tributario, como consecuencia de un procedimiento de devolución iniciado mediante autoliquidación, solicitud o comunicación (arts. 124 a 127 LGT), a través de la presentación de una autoliquidación complementaria para reintegrar el importe de la devolución improcedente. En estos casos se cumplen todos y cada uno de los requisitos establecidos en el art. 27 LGT para la aplicación de los recargos por presentación extemporánea de la autoliquidación, por lo que éste debería ser aplicado sobre el importe de la devolución reintegrada. AA.VV. (Coord. PELÁEZ MARTOS, J.M ${ }^{\mathrm{a}}$.): Todo procedimiento..op.cit.págs.251-252. Se acredita una conducta dirigida a eludir el pago de la cuota tributaria y, aunque la parte regularice la situación, lo hace de forma encubierta, dentro de una autoliquidación que no se corresponde con los períodos objeto de regularización (STSJ Extremadura, Sala de lo ContenciosoAdministrativo, Sec. 1. ${ }^{\mathrm{a}}$, 30.4.2015).

117 En aplicación de la STS de 27/09/2010, recurso de casación para la unificación de doctrina 308/2008, en la regularización voluntaria de las cuotas de IVA no es suficiente con ingresar las cuotas, sino que se tienen que cumplir unos requisitos (STSJ Cataluña, Sala de lo Contencioso-Administrativo, Sec. 1. a, 3.11.2011).

118 En cuanto a la interpretación de los requisitos necesarios para la aplicación de los recargos de este artículo, el Tribunal Económico-Administrativo Central ha establecido en distintas Resoluciones, como en la Resolución de 9 de mayo de 2001, que "estos requisitos son, en síntesis, los siguientes: 1) Que se presente la correspondiente declaración-liquidación o autoliquidación omitida o bien una declaración complementaria que rectifique la anterior formulada en plazo. En ambos casos deberá hacerse constar expresamente el período impositivo a que se refieren las bases y cuotas del Impuesto que son objeto de regularización. 2) Que la declaración sea extemporánea, es decir, que su presentación se realice una vez finalizados los plazos previstos por la normativa reguladora de los distintos tributos. 3) Que de la declaración-liquidación o autoliquidación presentada resulte una deuda tributaria a ingresar. 4) Que la presentación se efectúe de manera espontánea, sin que haya mediado requerimiento previo de los órganos de la Administración tributaria." En consecuencia, en el caso de la presentación de forma voluntaria y extemporánea de una declaración del Impuesto sobre la Renta de las Personas de la que resulta una cantidad a devolver según su escrito de consulta, no sería aplicable el régimen previsto en el artículo 61.3 de la Ley 230/1963, de 28 de diciembre, General Tributaria (consultas 1534 y 1535-04, SG de Tributos). La sanción no es correcta puesto que la diferencia que provocó el error aritmético del período 12 del ejercicio 2009, se tradujo en el período 3 del ejercicio 2010 en una diferencia que debió ser la base sobre la que se debía computar la infracción (STSJ Canarias, Santa Cruz de Tenerife, Sala de lo Contencioso-Administrativo, Sec. 1. ${ }^{\mathrm{a}}$, 3.7.2014).

119 Declaraciones-liquidaciones presentadas fuera de plazo, sin requerimiento previo y sin formular declaración complementaria: sanción y no recargo (STS, Sala Tercera, de lo Contencioso-Administrativo, Sec. 2. a 15.7.2011). La regularización 


\section{poránea $\sin ^{120}$ requerimiento previo ${ }^{121}$ establecido en el artículo $27.4^{\circ}$}

de la situación tributaria no podrá realizarse con el simple ingreso de la cantidad dejada de ingresar sino que es necesaria la declaración complementaria pues si no se considera extemporánea (STS, Sala Tercera, de lo Contencioso-Administrativo, Sec. 2. $\left.{ }^{a}, 14.7 .2011\right)$. La tipificación defectuosa del que regulariza su situación con posterioridad, lleva a la anulación de las sanciones tributarias al ser de aplicación -según indica el artículo los principios de legalidad y tipicidad (SAN, Sala de lo Contencioso-Administrativo, Sec. 6. ${ }^{\mathrm{a}}$, 8.7.2010).

120 Antes de la entrada en vigor de la Ley General Tributaria de 2003, bastaba el ingreso aunque se hiciera fuera de plazo, pero sin requerimiento previo, para que se excluyeran las sanciones (STSJ Castilla y León, Valladolid, Sala de lo Contencioso-Administrativo, Sec. 3. $\left.{ }^{\mathrm{a}}, 13.9 .2010\right)$. El régimen disciplinario previo a la LGT 58/03, mantiene que basta el ingreso, aunque se haga fuera de plazo, pero sin requerimiento previo, para excluir las sanciones que hubieran podido exigirse (SSTSJ Cataluña, Sala de lo Contencioso-Administrativo, Sec. 1. a, 25.2.2010 y 11.3.2010). El principio de culpabilidad constituye un elemento básico a la hora de calificar la conducta de una persona como sancionable. La norma excluye la sanción cuando la extinción o manifestación del crédito tributario se produce espontáneamente por el propio contribuyente (STSJ Cataluña, Sala de lo Contencioso-Administrativo, Sec. 1. $\left.{ }^{a}, 17.6 .2009\right)$. Con la anterior LGT, quedaban excluidas de sanción los supuestos de ingresos correspondientes a las declaraciones presentadas fuera de plazo sin requerimiento previo $\backslash$ En el ámbito del derecho sancionador son de aplicación los principios de legalidad y tipicidad, con prohibición de la interpretación extensiva y la analogía «in malam partem» (SAN, Sala de lo Contencioso-Administrativo, Sec. 6. ${ }^{\mathrm{a}}, 30.4 .2009$ ).

121 Siguiendo la SAN, Sala de lo Contencioso-Administrativo, Sec. 6. ${ }^{\text {, }}$, 21.12.2018, debemos tener muy en cuenta que Son dos los elementos que integran el presupuesto de hecho habilitante del recargo previsto en el art. 27 LGT: a) el primero de ellos, que se lleve a cabo por el obligado tributario una autoliquidación o declaración fuera de plazo; actividad que aquí no se pone en tela de juicio, con la salvedad de que la declaración del ejercicio 2011 que hace nacer el recargo es meramente complementaria de la que en su día se presentó, en forma tempestiva, en cumplimiento del deber de presentación de la autoliquidación; b) el segundo de ellos, que se lleve a cabo sin requerimiento previo de la Administración tributaria; concepto que según refiere el artículo 27 de la LGT puede adoptar varias formas o modalidades que a título ejemplificativo se reflejan en el precepto. Y precisamente el recurrente apoya su pretensión de nulidad de la liquidación por recargo en que en su caso la autoliquidación complementaria presentada en el mes de julio de 2013 respecto del IVA del periodo 12/2011 no se presentó de forma espontanea sino como consecuencia de una actuación administrativa previa de inspección tributaria... Por eso debemos ahora analizar en qué medida puede incluirse en el artículo 27.1 de la LGT la regularización tributaria efectuada por la inspección al Grupo de Entidades de IVA 194/2008 como "requerimiento previo de la Administración» que, en su caso, permitiría no exigir al recurrente recargo por la autoliquidación complementaria presentada en el mes de julio de 2013 respecto del IVA relativo al periodo diciembre de 2011. En consecuencia, a la vista de lo expuesto, esta sección entiende que la autoliquidación complementaria presentada por la recurrente el 30 de julio de 2013 fue realizada como consecuencia del conocimiento formal de la regularización tributaria realizada al Grupo de Entidades del IVA citado. Y como es esa regularización tributaria lo que justifica la presentación de la autoliquidación complementaria por la recurrente entonces, no se cumpliría el presupuesto imprescindible para que entrase en juego el recargo por presentación extemporánea de autoliquidaciones con resultado a ingresar. Ya que la exigencia del recargo 


\section{$\mathrm{LGT}^{122}$.}

únicamente surge cuando se presenta una autoliquidación de forma extemporánea y de forma espontanea. Y en el caso presente no podemos concluir que hubiera sido espontanea su presentación sino consecuencia de la referida regularización tributaria dada la evidente conexión directa entre la compensación de saldos efectuada por la inspección en los ejercicios 2008, 2009 y 2010 y su implicación en la compensación que la recurrente ya había realizado en el ejercicio 2011. En otras palabras, la única razón que llevó a la recurrente a presentar la autoliquidación complementaria en julio de 2013 fue la regularización tributaria efectuada habida cuenta de la conexión directa entre los importes a compensar, inseparables en cuanto que la compensación de un saldo en los ejercicios 2008, 2009 y 2010 afectaba inevitablemente a la compensación que la recurrente había efectuado en el ejercicio 2011 de esa misma cantidad. Frente a lo anterior se podría argumentar que el obligado tributario ha efectuado esa autoliquidación motu proprio, de forma voluntaria, sin que la Inspección le obligara a ello, razón por la cual cuanto se ha señalado anteriormente sobre la innecesariedad de tal autoliquidación perdería su razón de ser, pero tal alegato -que no se contiene en el escrito de contestación del Abogado del Estado, que no lleva su fundamentación jurídica a reflexiones de esta índole- no priva de valor a lo que se ha señalado con anterioridad respecto al valor de la autoliquidación... Además, si con el sistema gradual del recargo del articulo 27 LGT se trata de estimular el cumplimiento espontáneo de las obligaciones fiscales y, por ende, aplicar un gravamen de mayor intensidad cuanto mayor también sea la tardanza en el cumplimiento de ese deber, esa tardanza aquí es indiferente y puede ser perfectamente desligada de la voluntad del interesado. Siendo ello así, no es posible aplicar en este caso el 20 por 100 previsto para los supuestos en que la declaración se produjera una vez transcurridos los 12 meses desde el momento en que debió formularse la declaración, cuando dicha demora no dependió de la voluntad del recurrente, sino que estuvo condicionada, en su existencia misma y en el momento de presentarse la declaración complementaria, por los elementos ajenos a su conducta a los que constantemente nos venimos refiriendo. Por último, no se cumplen tampoco, en el caso presente, los fines institucionales para los que está prevista la imposición del recargo por declaración extemporánea, pues si el fundamento de éste es el de estimular el cumplimiento espontáneo de las obligaciones tributarias y, de forma equivalente, desincentivar su retraso, no cabría aquí considerar que la conducta del contribuyente debiera ser reprochada con ese gravamen, cualquiera que fuera su naturaleza jurídica, pues la autoliquidación formulada en su día para la declaración del Impuesto sobre el Valor Añadido correspondiente al ejercicio 2011, periodo diciembre, se realizó dentro del plazo legal, en tanto que la que se presenta con posterioridad -frente a la que se reacciona con la imposición del recargo no incurre en la hipótesis de la norma y, además, no lesiona o afecta al bien jurídico que se trata de proteger, lo que debería ser suficiente para excluirlo como respuesta del ordenamiento jurídico frente a la demora producida, atendida la razón determinante de esa segunda declaración, complementaria de la que se efectuó tempestivamente en su día. Es este, además, el criterio fijado por el Tribunal Supremo en la sentencia dictada en fecha 19 de noviembre de 2012 (recurso de casación $n^{\circ}$ 2526/2011)... la sentencia del Tribunal Supremo de 23 de mayo de 2016 (rec. de casación $n^{\circ}$ 1409/14)... no cambia la interpretación del artículo 27.1 de la LGT respecto del concepto del requerimiento previo que había expresado la sentencia del Tribunal Supremo de 19 de noviembre de $2012 \ldots$ Es este, además, el criterio seguido por esta Sección en la sentencia dictada en fecha 13 de diciembre de 2018 en el rec. $n^{\circ}$ 808/2017.

122 Este supuesto no se daría en el caso clásico juzgado por el TS en su Sentencia de 10 de noviembre de 1999, con ocasión de autoliquidación del

(C) UNED. Revista de Derecho UNED, núm. 26, 2020 
Por tanto, los únicos pagos fraccionados que pueden suponer la comisión de una infracción ${ }^{123}$ son aquellos que no se ingresan dentro de sus plazos reglamentarios y que, antes de realizarse la liquidación definitiva, final o recapitulativa (momento en el cual podrían deducirse en caso de ingreso o no deducirse en caso contrario) son requeridos por la Administración tributaria. En el caso de que ni se realicen los pagos fraccionados ni se presente la declaración definitiva o final del período, no ingresándose, por tanto, cantidad alguna en ningún momento, habría que entender que se ha producido la infracción del artículo 191.

\section{Otros supuestos de hecho infractores, consistentes en dejar de ingresar la deuda tributaria, no previstos en la LGT $^{124}$}

En el ámbito del Impuesto sobre la Renta de los No Residentes lo que el art. 28.2 del Real Decreto Legislativo 5/2004, de 5 de marzo,

ICIO. Así ANEIROS PEREIRA concluye que esta "doctrina jurisprudencial es válida en caso concreto tratado en esa sentencia, o sea respecto del ICIO, siempre que ... la Administración tributaria del Ayuntamiento de que se trate tenga pleno conocimiento de los datos necesarios para practicar liquidación provisional. En este caso, la falta de presentación de la autoliquidación y del ingreso correspondiente no puede considerarse como constitutiva de ocultación alguna, ya que es el propio sujeto quien le ha proporcionado a la Administración los datos reveladores de la realización del hecho imponible y la cuantificación del mismo". ANEIROS PEREIRA, J.:....op. cit. pág. 77; en igual sentido, SÁNCHEZ AYUSO, I.: Las circunstancias eximentes y modificativas de responsabilidad por infracciones tributarias, Marcial Pons, Madrid, 1996, pág. 37; Esto no será aplicable, claro está, cuando la autoliquidación presentada incluya ingresos correspondientes a conceptos y períodos impositivos respecto a los que se hubiera notificado previamente un requerimiento de la Administración tributaria. RUÍZ GARIJO,M.: “Infracciones y sanciones...",op. cit.", QF, núm. 4, 2005.

${ }_{123}$ El plazo de un mes para iniciar el expediente sancionador debe computarse desde la propuesta de regularización, no desde el inició de la comprobación de la situación tributaria. La única condición para exonerar de responsabilidad por infracción tributaria grave, es que se realice el ingreso sin que medie requerimiento previo de la Administración. El acuerdo de sanción ha incurrido en causa de nulidad, al haberse acreditado que concurren en este supuesto los requisitos legales de la regularización (STSJ Castilla y León, Valladolid, Sala de lo ContenciosoAdministrativo, Sec. 1. $\left.{ }^{\mathrm{a}}, 1.4 .2009\right)$.

124 En materia de operaciones vinculadas y su compatibilidad con el régimen sancionador establecido en en los arts. 191 a 195 LGT hay que estar a la STS de fecha 15 de octubre de 2018 (rec. Cas núm. 4561/2017) planteado contra la sentencia del Tribunal Superior de Justicia de Madrid, fecha 14 de junio de 2017. En conclusión, el TS establece que, en caso de encontrarnos ante un contribuyente que no tenga obligación de documentar sus operaciones (artículo 18 RIS), no será de aplicación el régimen sancionador especial (artículo 16.10. $1^{\circ}$ y $2^{\circ}$ ), siendo aplicable el régimen sancionador general (LGT). En definitiva, esta sentencia del TS establece que el régimen sancionador especial (artículo 16.10 TRLIS) no resulta de 
por el que se aprueba el texto refundido de la Ley del Impuesto sobre la Renta de no Residentes (TRLIRPFNR) no deja resuelto es la efectividad del régimen sancionador aplicable en el supuesto de renta exenta obtenida por un no residente, para el que exista obligación de presentar declaración. En primer término, se dice que el responsable solidario "podrá» presentar declaración del IRNR. Nada se dice sobre si es obligatorio que lo haga, puesto que la responsabilidad solidaria sólo se afirma inequívocamente sobre el ingreso de la deuda tributaria. En segundo término, y asumiendo su carácter obligatorio, cabe preguntarse si, al tratarse de una obligación del contribuyente por IRNR que el responsable solidario asume, en principio, en su condición de tal, y no como sujeto pasivo, este responsable solidario puede ser sancionado si no presenta la declaración de IRNR con exención.

En este sentido, si nos atuviéramos ${ }^{125}$ a la regulación genérica que de los responsables hace la LGT (art. 41.4 LGT), la responsabilidad de los mismos nunca alcanzaría a las sanciones, por lo que, en coherencia con este criterio, las impuestas por el incumplimiento de obligaciones formales no podrían reclamarse más que del contribuyente por IRNR, con la consiguiente merma de su eficacia, que haría inútil el propósito de control de la Administración tributaria en relación con estas rentas.

Existirán algunos supuestos dudosos, como en los casos en que existan exenciones ${ }^{126}$ como la prevista en el Real Decreto Legislativo

aplicación a aquellos contribuyentes que no están obligados a tener documentación de precios de transferencia (por no superar los umbrales correspondientes). En estos casos, en los que el contribuyente está exonerado del cumplimiento de esta obligación formal, no procede aplicar la exención de responsabilidad tributaria del artículo 16.10. $4^{\circ}$ TRLIS. Por tanto, para aplicar la exención de responsabilidad del artículo $16.10 .4^{\circ}$ TRLIS, será necesario: que nos encontremos ante un sujeto pasivo con obligación de documentar sus operaciones vinculadas; que no se haya incumplido la obligación formal de llevanza de la documentación; que el valor declarado por él en su declaración de renta coincida con el que se ha hecho constar en la documentación de la operación vinculada; y que, pese a la existencia de esta coincidencia documental, el valor de mercado que se haya atribuido a la operación vinculada sea incorrecto y haya precisado de una corrección valorativa por parte de la Administración tributaria. Únicamente en caso de cumplirse estas cuatro condiciones, el sujeto pasivo quedará exento de responsabilidad tanto vía régimen sancionador especial (artículo 16.10. $1^{\circ}$ y $2^{\circ}$ ) como vía régimen sancionador general (LGT).

125 AA. VV. (Coord. CRUZ AMORÓS,M.): Comentarios a la Ley del Impuesto sobre la Renta de las Personas Físicas y a la Ley del Impuesto sobre la Renta de No Residentes, Lex Nova, Valladolid,2003, págs.718-719.

126 Se exige que en el acuerdo sancionador que modifica las bases imponibles del IS, se motiven y justifiquen mininamente los elementos que las integran y los criterios de graduación aplicados (S TSJ Castilla y León, Valladolid, Sala de 
1/1993, de 24 de septiembre, por el que se aprueba el Texto refundido de la Ley del Impuesto sobre Transmisiones Patrimoniales y Actos Jurídicos Documentados (ITPAJD), respecto de Viviendas de Protección Oficial (art. 45.I.B.12.a y b TRLITP), donde el plazo de autoliquidación -aunque sea exenta- comenzará desde la transmisión, con independencia de que el particular disponga de tres años para obtener la calificación provisional. Será una vez transcurrido dicho plazo, sin la presentación de la calificación, cuando se volverá a iniciar un nuevo plazo donde el cómputo del plazo de prescripción previsto en el artículo 67 de la Ley 58/2003, de 17 de diciembre, General Tributaria, comenzará a contarse una vez transcurrido el plazo de tres o cuatro años de exención provisional, lo que amplía, entendemos, hasta ocho años el plazo prescriptivo ${ }^{127}$.

En el caso previsto en el art. 36.2 TRLIRPFNR - en este supuesto (caso de entidades en régimen de atribución de rentas que no desarrollen una actividad económica en territorio español), y sin perjuicio de lo dispuesto en el apartado 3, la entidad en régimen de atribución de rentas estará obligada a ingresar a cuenta la diferencia entre la parte de la retención soportada que le corresponda al miembro no residente y la retención que hubiera resultado de haberse aplicado directamente sobre la renta atribuida lo dispuesto en el artículo 31de esa Ley-, entendemos ${ }^{128}$ que se trata de una figura calificable y asimilable a un sustituto del obligado a retener o ingresar a cuenta (v.gr. el arrendatario residente), aunque sólo por la parte del cumplimiento de la prestación tributaria que dicho obligado a retener o ingresar a cuenta no hubiera podido ejecutar debido a la aplicación estricta de la normativa del IRPF de residentes, en cuyo caso podrían

lo Contencioso-Administrativo, Sec. $3{ }^{\mathrm{a}}$, 20.7.2015). La base imponible del ITP y AJD en supuestos de escritura de dación en pago está constituida por el valor de la deuda que con la entrega del bien se salda, pero no es cuestión que haya resultado pacífica en Derecho, por lo que se anula la sanción (STSJ Madrid, Sala de lo Contencioso-Administrativo, Sec. 9. a , 3.7.2014). Se anula la sanción tributaria derivada del ITP y AJD por falta de culpabilidad, puesto que el transmitente de la vivienda tiene la condición de empresario que ha actuado en el ejercicio de su actividad, abonando la interesada el IVA en lugar del ITP (STSJ Castilla y León, Valladolid, Sala de lo Contencioso-Administrativo, Sec. 2. $\left.{ }^{\mathrm{a}}, 6.6 .2014\right)$. El propietario de la finca no actuaba como sujeto pasivo del IVA al no haber soportado costes de urbanización sobre los terrenos que ha permutado, por lo que la operación no estaba sujeta a IVA, y sí al ITP. No procede la imposición de la sanción porque el interesado ha mantenido una interpretación razonable de la norma, puesto que se podía pensar que la finca se adquiría del promotor de las obras (STSJ Andalucía, Sevilla, Sala de lo Contencioso-Administrativo, Sec. 2. a , 9.3.2012).

127 FERNÁNDEZ JUNQUERA,M.: La prescripción de la obligación tributaria. Un estudio jurisprudencial, Aranzadi, Pamplona, 2001, págs.41-43.

128 AA. VV. (Coord. CRUZ AMORÓS,M.): Comentarios...op.cit.págs.756-757. 
serle impuestas sanciones por el incumplimiento de estas obligaciones, aunque la no inclusión de este tipo de ERAR en la enumeración del art. 31 TRLIRPFNR hace entender que se descarte su consideración como retenedor u obligado a ingresar a cuenta.

Cuando se haya cometido la infracción prevista en el artículo 170. dos. $4^{\circ}$ de la Ley 37/1992 ${ }^{129}$, de 28 de diciembre, del Impuesto sobre el Valor Añadido ${ }^{130}$, o la prevista en el artículo 63.5 de la Ley 20/1991,

129 Art. 170.2.4 LIVA, constituye infracción tributaria la no consignación en la autoliquidación que se debe presentar por el periodo correspondiente de las cantidades de las que sea sujeto pasivo el destinatario de las operaciones conforme a los números $2 .^{\circ}, 3 .^{\circ}$ y $4 .^{\circ}$ del artículo 84.uno, del artículo 85 o del artículo 140 quinque de esta Ley."

${ }_{130}$ En este ámbito [penal] existe una notable confusión sobre la naturaleza instantánea o periódica del IVA y la significación que cabe atribuir a los períodos de liquidación. Y esa confusión afecta, de modo harto preocupante, a la idea que los tribunales penales tienen sobre el inicio del cómputo de la prescripción del delito contra la Hacienda Pública del art. 305CP .El Tribunal Supremo considera que el dies a quo en relación con la prescripción del delito contra la Hacienda Pública cometido en el IVA se sitúa el día 30 de enero de cada año. Así, en la Sentencia de 14 de noviembre de 2005 , se dice que es Doctrina seguida unánimemente por los tribunales inferiores: SAP Cádiz de 24 de junio de 2003(sección $1^{\text {a }}$; ponente: Ilma. Sra. Dña. Rosa FERNÁNDEZ NÚÑEZ); SAP Barcelona ${ }^{\circ}$ 590/2005 (sección $5^{\text {a }}$ ), de 13 de mayo (rec. no 299/2005; ponente: Ilmo. Sr. D. Guillermo BENLLOCH PETIT);SAP Albacete ${ }^{\circ}$ 98/2000, de 4 de septiembre (sección $2^{\text {a }}$. Rec. $n^{\circ}$ 1100/2000; Ponente: Ilmo. Sr. D. Antonio NEBOT DE LA CONCHA);SAP Zaragoza $n^{\circ}$ 380/2005 (sección $3^{\mathrm{a}}$ ), de 13 de septiembre (rec. $\mathrm{n}^{\mathrm{o}}$ 357/2004; ponente: Ilmo. Sr. D. Roberto GARCÍA MARTÍNEZ);SAP Barcelona $n^{\circ}$ 224/2010 (sección 3a), de 4 de marzo (ponente: Ilma. Sra. Dña. $M^{\mathrm{a}}$ Jesús MANZANO MESEGUER).SAP Barcelona ${ }^{\circ}$ 270/2010 (sección $2^{\text {a }}$ ), de 28 de abril (ponente: Ilmo. Sr. D. Pedro MARTÍN GARCÍA). ${ }^{\circ}$ 1599/2005. Recurso no 2522/2003. Ponente: Excmo. Sr. D. Siro Francisco GARCÍA PÉREZ. En el mismo sentido la STS 827/2006, de 10 de julio. Ponente: Excmo. Sr. D. Francisco MONTERDE FERRER. «el delito fiscal, en la faceta que nos ocupa, como infracción del deber de contribuir se consuma en el momento en que vence el plazo legal voluntario para realizar el pago -véanse sentencias del 03/01/2003 y 30/04/2003, TS-. Y el art. 132.1 CP, antes art. 114 CP 73, señala como dies a quo aquél en que se haya cometido el delito. En consecuencia ha de tomarse el 20/01/1992 o el 30/01/1992 cual día inicial del cómputo prescriptivo. Sin que se encuentre fundamento para desligar el art. 305.2 CP, antes 349.2 CP 73, de su art. 132.1»(FJ $\left.8^{\circ}\right)$.Las consecuencias de este planteamiento pueden ser funestas. En la SAP Madrid no 452/2006 (sección 17a), de 24 de mayo (rec, núm. 113/2006; ponente: Ilma. Sra. Dña. Rosa BROBIA VARONA) se dice : la prescripción está en función de la consumación del delito y en este caso sólo se ha consumado cuando a través de la liquidación anual se puede determinar si la suma defraudada excede o no del límite legal». Sostiene que el período se extiende hasta el 30 de enero debido a que es la fecha en que finaliza la declaración de pago voluntario y hasta esa fecha el contribuyente tiene la oportunidad de cumplir su obligación de modo que hasta que dicha obligación no se ha inobservado de forma definitiva no puede decirse que se ha producido lesión del bien jurídico protegido. Luego, y así consuma lo que califica de interpretación teleológica, sólo cuando se haya hecho el balance total del ejercicio fiscal, "y este balance se realiza el 31 de

(C) UNED. Revista de Derecho UNED, núm. 26, 2020 
enero del año siguiente en el resumen anual de la declaración, será entonces cuando si obtenemos una cantidad a ingresar superior al máximo considerado típico por la ley penal, y no se ingresa dicha cantidad estaremos ante la consumación de la elusión del tributo» $\left(\mathrm{FJ}^{\circ}\right)$... En el plano fiscal, sin embargo, si se deja de pagar el IVA de un trimestre ya se produce infracción siendo innecesario esperar al 31 de enero del año siguiente. Por descontado, la regularización, en los términos del art. 27LGT, puede empezar a practicarse desde el día siguiente a aquel en el que concluye el período de liquidación mensual o trimestral sin tener que esperar al 31 de enero. Ese día, en ningún caso, finaliza el período voluntario de pago del impuesto en relación con un ejercicio determinado, que es lo que llega a afirmarse en la SAP Barcelona núm. 92/2009 (sección $8^{\mathrm{a}}$ ), de 30 de enero (rec. $\mathrm{N}^{\mathrm{o}}$ 240/2008; ponente: Ilmo. Sr. D. Carlos MIR PUIG), en la SAP Valencia núm. 130/2009 (sección $3^{\text {a }}$ ), de 23 de febrero ( $n^{\circ}$ rec. 42/2009); ponente: Ilmo. Sr. D. Fco. PASTOR ALCOY) y en la SAP Madrid núm. 1007/2008 (sección 17 ), de 7 de octubre (nº rec. 258/2008; ponente: Ilma. Sra. Dña. ROSA BROBIA VARONA).Llega a esa conclusión, entendemos, a causa de una defectuosa comprensión de lo que dice el art. 305.2 CP... Aun así, frecuentemente, los tribunales penales confunden la finalidad del mandato del art. 305.2, determinar la forma de calcular la cuota defraudada en determinado tipo de tributos, con el establecimiento de un nuevo sistema de cómputo de la prescripción tributaria. Sin embargo, como vemos, la ley penal no dice nada al respecto de modo que no hay normas penales especiales sino que el juez penal tiene que ceñirse tanto a la norma general de prescripción establecida en el CP como a las normas tributarias, al complemento extrapenal de esa norma penal en blanco que es el art. 305. Y en Derecho Tributario la prescripción se inicia al finalizar el plazo de presentación de la autoliquidación sin que el IVA presente excepción alguna al respecto. Luego, el plazo de prescripción de este impuesto empieza cuando finaliza el plazo de presentación de cada autoliquidación mensual o trimestral, según ha defendido FALCÓN TELLA... retomando la Sentencia del mismo Tribunal $n^{\circ}$ 520/2008: «el día a quo para iniciar el cómputo del tiempo necesario para la prescripción se corresponde con la consumación del delito, que se produce el último día del plazo voluntario para presentar la liquidación del impuesto» $\left(\mathrm{FJ} 5^{\circ}\right)$.Ese día es aquel en que también en Derecho Tributario se entienden cometidas las infracciones conforme al art. 189.2 de la LGT de 2003. Si se pone en relación este último precepto, por ejemplo, con el 191, regulador de las principales infracciones consistentes en dejar de pagar tributos, veremos como la consumación de la infracción se sitúa en el momento en que se ha dejado de ingresar «dentro del plazo establecido en la normativa de cada tributo la totalidad o parte de la deuda tributaria que debiera resultar de la correcta autoliquidación del tributo». Ese plazo, en el caso del IVA, coincide con «los veinte primeros días naturales del mes siguiente al correspondiente período de liquidación mensual o trimestral, según proceda». Luego, excede del mandato de la ley tributaria, y de la letra también de la ley penal, retrasar el inicio del cómputo del plazo de prescripción penal hasta el último día de presentación de la declaración-resumen anual, declaración de naturaleza meramente informativa, que no incorpora ninguna liquidación tributaria, o, si se prefiere hasta el último día del plazo de autoliquidación del último período de liquidación de cada año. Lo ha dicho con toda claridad el Tribunal Superior de Justicia del País Vasco en el FJ $4^{\circ}$ de su Sentencia $n^{\circ} 794 / 2008$, de 24 de noviembre... Por consiguiente, es erróneo considerar que cabe rectificar antes del 31 de enero en relación con el IVA que debió haber sido correctamente autoliquidado en los períodos correspondientes al año inmediato anterior. Al contrario, los efectos materiales de cada devengo encuentran su lugar en la autoliquidación correspondiente al período durante el 
de 7 de junio ${ }^{131}$, de modificación de los aspectos fiscales del régimen económico fiscal de Canarias, no se impondrá sanción por las infracciones previstas en los artículos 191, 193, 194 ó 195 de la Ley 58/2003, de 17 de diciembre, General Tributaria, que se hubiesen originado por la no-consignación de cantidades en la autoliquidación, y deberán imponerse las sanciones correspondientes a las infracciones previstas en dichas normas. En estos casos el sujeto pasivo -que se invierte-, y al caso presunto infractor, no es el empresario o profesional que efectúa las operaciones sino el destinatario de las mismas, y en las operaciones intracomunitarias es sujeto pasivo la persona que las realiza, y por tanto, el destinatario de los bienes que realmente han llegado a España ${ }^{132}$ (Disposición Adicional $3^{\text {a }}$ del RGRST).

\section{Circunstancias calificativas de la infracción}

El criterio general, base de la calificación de las infracciones como muy graves, ha sido objeto de comentario y crítica ${ }^{133}$. Úni-

cual se produjo, el mes o el trimestre. No es trasladable un devengo acaecido, por ejemplo, en el segundo trimestre, a autoliquidaciones posteriores aunque no se haya rebasado el 31 de enero del año siguiente. Tan es así que, si ese supuesto se produce, la LGT, y salvo que se efectúe una regularización expresa con recargo (art. 27.4), considerará que se ha cometido una infracción tributaria, la del art. 191.6, STSJ Asturias de 1 de marzo de 2002... Para terminar, si el art. 305.2 no hiciera mención expresa al año natural «a los efectos de determinar la cuantía» defraudada sino únicamente a un período anual, en caso de que en una defraudación de IVA la prescripción tributaria alcanzara a los dos primeros trimestres del año, una posibilidad sería tomar en consideración para el cómputo anual, junto los dos restantes trimestres de ese año, los dos primeros del siguiente, totalizando así un año, aunque no fuera «el año natural»...«No tendría sentido que una defraudación por más de 15 millones concentrada en el último trimestre de 2002 prescriba penalmente a los 5 años a contar desde el 30 de enero siguiente, es decir el 30 de enero de 2008. Y que, en cambio, la misma infracción concentrada en el primer trimestre de 2003 (sin descubierto alguno en los períodos posteriores) no prescriba penalmente hasta el 30 de enero de 2009, que es a lo que conduciría la tesis que se critica: una defraudación cometida materialmente sólo tres meses después, prescribiría un año más tarde». ALONSO GONZÁLEZ,L.M.; TOVILLAS MORÁN,J. $M^{\mathrm{a}}$.: "La posición del TEAC sobre los períodos de liquidación del IVA y su trascendencia penal", Quincena Fiscal Aranzadi, núm. 1, 2011, BIB 2011\60.

131 Art. 63.5 Ley 20/1991 (DA 3 RGRST): constituye infracción tributaria la no consignación en la autoliquidación a presentar por el período correspondiente de las cuotas de las que sea sujeto pasivo el destinatario de las operaciones conforme al apartado $2 .^{\circ}$ del número 1 del artículo 19 y el número 6 del artículo 58 ter, ambos de esta Ley y el apartado 2 del artículo 25 de la Ley 19/1994.

132 Se trata de supuestos de autorepercusión por el destinatario de la operación gravada. GARBERÍ LLOBREGAT, J. et alii: Procedimiento Sancionador...op.cit. págs.792 y 849 .

133 SÁNCHEZ HUETE, M.A.: “Elementos para un análisis...”, op. cit.pág.184.

(C) UNED. Revista de Derecho UNED, núm. 26, 2020 
camente reiterar que, dado que la infracción base requiere ocultación ${ }^{134}$, la utilización fraudulenta de tales medios ${ }^{135}$ comportará normalmente ${ }^{136}$ dicha intención. De ahí, que se esté valorando nuevamente un aspecto ya sancionado, y no podrá punirse reiteradamente, como sustentamos al comentar las infracciones anteriores. Respecto de la circunstancia específica mencionada opera independientemente de la concurrencia de los anteriores medios fraudulentos, ya que tiene lugar cuando la conducta recaiga en una parte específica de la deuda tributaria: los pagos a cuenta. El concreto objeto material de la conducta resulta el elemento vertebrador de la calificación, y así el precepto efectúa la mención expresa. Se parte de dos comportamientos básicos que basculan en torno a la conducta de dejar de ingresar; uno de perjuicio, cuando se ha practicado la retención y; otro de peligro, sin haber practicado la misma. Son conductas diversas que son tratadas como si fueran iguales, o sea, sin tener en cuenta su diversa lesión.

134 No se ha probado una interpretación razonable de la norma, porque no hay duda de que los ingresos derivados de la actividad se consideran obtenidos por el titular de la actividad. La infracción es leve, ya que aunque la base de la sanción supera la cifra de 3000 euros, la Administración no apreció la circunstancia de ocultación (STSJ Andalucía, Granada, Sala de lo Contencioso-Administrativo, Sec. 2. $\left.{ }^{\mathrm{a}}, 27.12 .2011\right)$. La resolución sancionadora está motivada porque el interesado tenía conocimiento de los hechos por los que se impone la sanción por no presentar la declaración del Impuesto sobre el Patrimonio \No existe buena fe porque la interesada tenía conocimiento de la obligatoriedad de la presentación de la declaración del Impuesto sobre el Patrimonio, pues la había ya presentado en ejercicios anteriores. La Ley 58/2003 es más favorable al disponer qué cuando la base de la sanción sea inferior a 3.000 euros, aunque concurra ocultación, la infracción es leve, y se sanciona con multa proporcional del 50\% (STSJ Andalucía, Granada, Sala de lo Contencioso-Administrativo, Sec. 2. ${ }^{a}$, 12.12.2011). La infracción cometida por dejar de ingresar todo o parte de una deuda tributaria será leve cuando la base de la sanción sea inferior a 3.000 euros, aunque haya ocultación, siendo también leve superando dicha cuantía siempre que no exista ocultación (STSJ Andalucía, Granada, Sala de lo Contencioso-Administrativo, Sec. 2. , 18.4.2011).

135 No es adecuado a Derecho el incremento de la sanción por ocultación puesto que, la mera inexactitud en la declaración, no implica necesariamente que exista ocultación (STSJ Asturias, Sala de lo Contencioso-Administrativo, Sec. 2. ${ }^{\text {, }}$, 9.12.2005).

136 No siempre que se deba acudir a una estimación indirecta por anomalías sustanciales en contabilidad debe, automáticamente, considerarse la infracción como de muy grave por entenderla cometida mediante la utilización de medios fraudulentos ya que como dice el TS en las sentencias que se citan “...sólo las anomalías contables especialmente buscadas con el propósito de eludir el pago de los impuestos debidos a sabiendas de su falsedad, de su ilegalidad o de su significación engañosa o falaz, podrán tener el aludido carácter de circunstancia de agravación”.(Ley 58/2003, General Tributaria: arts. 53.1.c), 191.4 y 184.3.a).3.) [RTEAC, Vocalía 2. a , 30.4.2009]. 
Según los apartados 2 y 3 del artículo 191 de la LGT se agravará la infracción cuando además exista, según el artículo 4.1 del RGRST, ocultación de datos a la Administración tributaria, que se dará cuando se produzcan las circunstancias previstas ${ }^{137}$ en el artículo 184.2 de la Ley 58/2003, de 17 de diciembre, General Tributaria, aún cuando la Administración tributaria pudiera conocer la realidad de las operaciones o los datos omitidos por declaraciones de terceros, por requerimientos de información o por el examen de la contabilidad, libros o registros y demás documentación del propio sujeto infractor ${ }^{138}$. Sin embargo, el tipo agravado no necesariamente

137 La ocultación no puede estimarse como un criterio de graduación de las sanciones salvo en los supuestos expresamente previstos (STSJ Cataluña, Sala de lo Contencioso-Administrativo, Sec. 1. $\left.{ }^{\mathrm{a}}, 25.1 .2010\right)$.

138 GARBERÍ LLOBREGAT, J. et alii: Procedimiento Sancionador...op.cit. págs.640 y 1239; En sentido contrario GARCÍA BERRO, para quien incluso se incurre en el tipo agravado cuando reflejada la imagen fiel y completa, la liquidación realizada arroja, por cualquier causa, un saldo más favorable a éste que el se derivaría de la correcta aplicación de las normas reguladoras del tributos. También se incurre cuando se declara de forma completa y veraz seguida de una incorrecta liquidación. Concluye, que no se puede rechazar de modo automático la existencia de culpa por el mero hecho de que se presente una declaración correcta y veraz; GARCÍA BERRO, F.: Los procedimientos tributarios y derechos de los contribuyentes en la Nueva Ley General Tributaria, Marcial Pons,Madrid, 2004, págs. 173 y 174; Muy difícilmente puede hablarse de ocultación cuando el propio obligado tributario ha reflejado fielmente sus operaciones en los libros contables. JUAN LOZANO,A.M. et alii. VVAA.: Manual sobre la Ley 58/2003, de 17 de diciembre, General Tributaria. IV. "Régimen Sancionador tributario", Escuela de Formación de la Asociación Española de Asesores Fiscales, 2004, pág. 31; Esto es, cuando el obligado es consciente de que la Administración tiene en su poder los datos tributarios ocultados. Así las SsTS de 10 de noviembre de 1999, 4 de marzo de 2003, 29 de abril de 2004, SAN de 19 de septiembre de 2001; Han de ser los tribunales los que pongas las cosas en sus justos términos y ponderen la gravedad de las omisiones de los datos en que incurran los contribuyentes en atención a una pluralidad de criterios, teniendo en cuenta las disponibilidades de información en manos de los entes públicos. CAYÓN GALIARDO, A.: "La potestad sancionadora en el orden tributario", RTT, núm. 65, 2004,pág. 14; No hay ocultación cuando no se declara una operación que está facturada, contabilizada y registrada, ...es razonable entender que lo contabilizado, registrado, justificado y aportado - si se comprobara- impide apreciar ánimo de ocultación. BANACLOCHE PÉREZ-ROLDÁN,J.: Guía práctica de sanciones tributarias, La Ley, Madrid, 2005, pág. 63.Autor que considera ilegal la dicción y demás documentación del propio sujeto infractor pues es contraria al sentido de la ocultación culposa y a la razón, no pudiendo considerarse incluso cuando se comuniquen los datos a través de obligaciones general de información impuestas a terceros; A la luz de la doctrina del Tribunal Supremo citada y siempre que la Administración Tributaria practique o deba practicar una liquidación provisional de oficio de las denominadas comprobaciones abreviadas (art. 121 LGT), no habrá, por supuesto, infracción tributaria grave, en la medida en que no hay ocultación. ANÍBARRO PÉREZ, S. y SESMA SÁNCHEZ, B.: Infracciones...op.cit., pág. 71; para LAMOCA no habría ocultación cuando la Administración tributaria pudiera conocer la 
se da cuando se deja de ingresar una deuda tributaria resultante de una autoliquidación, aunque se haya presentado una declaración incompleta o no veraz del hecho imponible. Esta misma argumentación resultaría igualmente válida para los supuestos agravados de los artículos 192 y 193 de la LGT, que posteriormente se tratan.

La propia LGT define la ocultación como ocultación de datos a la Administración, lo que acontece cuando no se presenten declaraciones o se presenten declaraciones en las que se incluyan hechos $\mathrm{u}$ operaciones inexistentes o importes falsos o en las que se omitan total o parcialmente operaciones, ingresos, rentas, productos, bienes o cualquier otro datos que incida en la determinación de la deuda tributaria ${ }^{139}$, siempre que la incidencia de la deuda derivada de la ocultación en relación con la base de la sanción sea superior al 10 por 100 (art. 184.2 LGT). Lo que resulta de esta definición ${ }^{140}$ es que existe ocultación en todo caso, cuando se haya dejado de presentar la declaración -aún cuando estos datos obren ya en poder de la Administración- y también cuando se haya presentado una declaración con datos omitidos o falseados en una cuantía tal que la deuda deri-

realidad de las operaciones o los datos omitidos por declaraciones correctas de tributos que tuviesen una relación directa, en cuanto a esos datos, con el que se estuviese comprobando. Así buena prueba de ello es el tenor literal del art. 131.b) LGT que obliga a instruir procedimiento de verificación de datos cuando los datos declarados no coincidan con los contenidos en otras declaraciones presentadas por el mismo obligado....v.gr. IVA e IS. LAMOCA PÉREZ,C.: Infracciones... op.cit., pág.320; Dicho precepto no duda tampoco en calificar al imputado en el procedimiento sancionador como infractor. Con tal mención se llega al absurdo de afirmar la ocultación aunque exista el conocimiento y no se dé lesión a bien jurídico alguno... El reglamento efectúa una interpretación auténtica del concepto de ocultación que se extralimita respecto de la dicción legal y contraría el sentir sancionador, en concreto, la vigencia del principio y elemento de la antijuridicidad. SÁNCHEZ HUETE,M.A.; “Una visión crítica...op.cit.”, BIB $2006 \backslash 327$.

139 Paradójicamente algún conflicto en la interpretación de las normas podemos colegir del apartado $2^{\circ}$ del art. 4 TRLIRPFNR, sobre no residentes en Ceuta y Melilla a los que parece que les resultaría de aplicación la bonificación del $50 \%$ contenidas en las Leyes del IRPF e IS, y sin embargo, los arts. 24 y 26 del TRLIRPNR impiden la aplicación de esa bonificación a contribuyentes que operen sin establecimiento permanente...por lo que ante dicha contradicción se concluye que podrá aplicarse la deducción del 50 por 100 siempre que cumpla los requisitos exigidos v.gr. en el art. 33 TRLIS [hoy, art. 33 de la Ley 27/2014, de 27 de noviembre, del Impuesto sobre Sociedades -LIS-]. SERRANO ANTÓN,F.....op.cit. págs.20-21.

140 Podría concluirse que estamos ante un tipo similar al del delito del art. 305 $\mathrm{CP}$, aunque sin el requisito de la cuantía y con inclusión de formas culposas. La conclusión, sin embargo, no es tan clara, por una razón: el tipo del CP requiere una conducta de ocultación. Sin embargo, en el de las infracciones de que hablamos (arts. 191 a 193 LGT), basta con que la declaración o autoliquidación sea incorrecta, sin llegar al nivel de la ocultación. PÉREZ ROYO,F.: Derecho Financiero ...2009,op.cit.pág.403. 
vada de la ocultación sea superior al 10 por 100 del total de la deuda dejada de ingresar. O sea, que puede existir deuda dejada de ingresar sin necesidad de ocultación, lo que sucederá cuando el obligado tributario, en su autoliquidación, declare los hechos sin omisión ${ }^{141}$ ni falsedad alguna, pero aplica incorrectamente las normas jurídicas o realiza mal los cálculos numéricos. Lo importante, en todo caso, es que la Ley de 2003 ha dejado claro que puede existir infracción sin ocultación, es decir, que la ocultación no forma parte del tipo infractor, lo cual era objeto de discusión en la doctrina que trató el texto anterior.

Igualmente se agravará la infracción por el empleo de medios fraudulentos ${ }^{142}$ en los supuestos del apartado $4^{\circ}$ de los artículos 191, 192 y 193 de la LGT, medios que determina el artículo 184.3 de la LGT. Según las Sentencias de 2 de abril de 1992 del Tribunal Supremo, y de 5 de abril de 2001 de la Audiencia Nacional, no cabe considerar ausencia, en todo o en parte, de contabilidad cuando no afecte a la exacción del tributo, siempre que pueda realizarse en virtud de los documentos aportados por el propio obligado, de modo que dicha circunstancia vendrá ya contenida en la propia infracción consistente en dejar de ingresar la totalidad o parte de la deuda tributaria, siendo lo procedente calificar la infracción como de omisión por la presentación inexacta ${ }^{143}$.

141 La omisión de las rentas en la declaración de IRPF se ha hecho sin intención, ya habían sido objeto de retención y eran de fácil conocimiento por la propia AEAT (STSJ Murcia, Sala de lo Contencioso-Administrativo, Sec. 2. ${ }^{\text {, }}$, 9.12.2015).

142 El empleo de medios fraudulentos, como la utilización de una empresa «fantasma», presuponen una voluntad inequívocamente dirigida de forma consciente a minorar la deuda tributaria y defraudar (STSJ Extremadura, Sala de lo Contencioso-Administrativo, Sec. 1. a , 12.5.2015). Si bien no considerándose uno a uno los indicios, sino en su conjunto, se entiende acreditado que las empresas vinculadas han realizado facturaciones de servicios que no han sido prestados, siendo procedente la sanción tributaria. Se ajusta a Derecho la sanción impuesta, en la medida en que no es una interpretación de los valores de mercado que ha de aplicarse en transacciones entre vinculadas, sino la inexistencia de servicios que han sido facturados. Puesto que la actitud de la recurrente ha implicado el poder de dirección sobre compañías vinculadas para simular unos servicios que no se han realizado, se entiende que se han utilizado medios fraudulentos a efectos de calificar la sanción (STSJ Andalucía, Sevilla, Sala de lo Contencioso-Administrativo, Sec. 4. ${ }^{\text {a }}, 3.7 .2012$ ). El conjunto de los indicios trazan una evidencia de la simulación absoluta de la relación de servicios, no siendo suficiente desacreditarlos sin más. Utilizar el poder de dirección común de las compañías vinculadas para simular servicios, para deducirse con facturas formalmente válidas, supone utilización de medios fraudulentos (STSJ Andalucía, Sevilla, Sala de lo ContenciosoAdministrativo, Sec. 4. $\left.{ }^{\mathrm{a}}, 7.10 .2011\right)$.

143 En contra de mantener dicha postura jurisprudencial GARBERÍ LLOBREGAT, J. et alii: Procedimiento Sancionador...op.cit.T.I.pág.647; Sin

(C) UNED. Revista de Derecho UNED, núm. 26, 2020 
Respecto de la exigencia de ocultación ${ }^{144}$ en el $2^{\circ}$ párrafo del art. $191.3^{\circ}$ LGT, se ha de tener presente que la infracción base requiere de la misma para su afirmación. De ahí, que no podrá volverse a apreciar ${ }^{145}$ dicho aspecto como elemento que califique tal infracción. Dicho planteamiento se deriva de la afirmación del principio punitivo non bis in idem que proscribe la doble valoración de un mismo hecho. Traemos a colación que la sentencia del Tribunal Constitucional de 30 de enero de 1981 reconoce el principio llamado de non bis in idem ${ }^{146}$, íntimamente unido al principio de legalidad de las in-

embargo, no procede la sanción por no repercutir el IVA si se ha sancionado por ocultación de operaciones no facturadas (RTEAC 24.04.1997).

${ }_{144}$ La ocultación, inherente a una actividad de simulación, no debe considerarse como criterio de graduación de la sanción sino como determinante de la calificación de la infracción (STS, Sala Tercera, de lo ContenciosoAdministrativo, Sec. 2. ${ }^{\mathrm{a}}, 24.2 .2016$, que cuenta con un Voto particular).

145 La omisión del registro de la factura califica la infracción como muy grave, por los efectos derivados de un mismo hecho (RTEAC, Vocalía 12. a 21.1.2016, unificación de doctrina).

146 También en el ámbito administrativo pueden darse casos de doble sanción por facturación falsa, así el objeto del debate en este tipo de procedimientos se circunscribe a dilucidar si es posible exigir a una empresa (que llamaremos responsable) las sanciones que en su día se impusieron a otra entidad (la obligada principal), considerando la Administración que la primera sería responsable, en virtud del 42.1.a) de la LGT, por colaborar con la obligada principal en la comisión de la infracción consistente en emitir facturas falsas, teniendo en cuenta muy especialmente que ya se había sancionado previamente a la ahora pretendidamente responsable por haber utilizado esas mismas facturas para mermar su cuota tanto de Impuesto sobre el Valor Añadido (IVA) como de Impuesto sobre Sociedades (IS).El argumento principal: no se puede sancionar dos veces un mismo hecho. Es evidente, en nuestra opinión, que el argumento principal a esgrimir frente a este tipo de acuerdos es el de la imposibilidad de que se sancione dos veces por el mismo hecho, por atentar contra el principio del non bis in idem. La obligada principal ya fue sancionada por comisión de infracción tributaria muy grave del artículo 201 de la LGT 58/2003 por la emisión de facturas que se califican de «falsas», por corresponderse con trabajos no realizados en el ejercicio 2005.Parte de esas facturas falsas se habían emitido a la sociedad a la que ahora se quiere hacer responsable. La cuestión es que, a continuación, y gracias a la documentación que había aportado la obligada principal en su propio procedimiento de comprobación o sancionador, la Inspección ya abrió procedimiento de comprobación frente a la receptora de dichas facturas, incoándosele también sendos expedientes sancionadores por IVA y por IS. Considerando la Inspección que no se había acreditado la realidad de las operaciones realizadas por la emisora, la receptora es sancionada por aplicación de los artículos 191 y 195 de la LGT, por dejar de ingresar en IVA y en IS el importe que hubiera correspondido de no haber utilizado estas facturas recibidas. Es muy importante destacar que en la cuantificación de las anteriores infracciones se tuvo en cuenta como criterio de graduación "la utilización de medios fraudulentos", en concreto, el empleo de las facturas falsas emitidas. Poco después la Administración Tributaria, desde su Dependencia de Recaudación, inicia un expediente de derivación de responsabilidad solidaria a la receptora de las facturas, considerándola causante o colaborador activo (ex art. 42.1 a) LGT) en la realización de la infracción tributaria cometida por la otra empresa, 


\section{fracciones que recoge el artículo 25 de la Constitución. Dicho prin-}

consistente en emitir facturas falsas... El nudo gordiano de este asunto está en que para la Administración hay dos acciones distintas, una colaborar en la falsificación de facturas, y otra, dejar de ingresar parte de la deuda tributaria,...En efecto, y dicho de otra manera, en realidad no hay dos acciones distintas, sino, precisamente y tal y como establece el artículo 180 (antes apartado 2 hoy apartado 3), una misma acción u omisión que debe aplicarse necesariamente en este caso como criterio de graduación de una infracción, y que por tanto, no puede ser sancionada como infracción independiente. Pero es que aun en la hipótesis de que existiera otra infracción, esta otra infracción no puede ser sancionada como infracción independiente, puesto que esa colaboración con la emisora de las facturas falsas ya ha sido tenida en cuenta como criterio de calificación de la infracción por la que ya ha sido sancionada. El artículo 184 LGT considera que constituyen medios fraudulentos el empleo de facturas, justificantes $\mathrm{u}$ otros documentos falsos o falseados; ... lo que no es posible es, como dice el 180.3, sancionar esas dos acciones cuando una de ellas ya haya sido tenida en cuenta como criterio de graduación de la otra infracción por la que un sujeto ya ha sido sancionado... De hecho, el mismo razonamiento que utiliza el TEAR para defender su postura, sirve para defender la contraria,...[]En relación a la derivación de la responsabilidad] no es defendible la tesis que parece querer sostener la Administración en este tipo de Acuerdos, que podría resumirse en que ahora la Administración puede "volver a sancionar» porque en realidad lo que está haciendo no es sancionar de nuevo vulnerando el principio del non bis in idem, sino que lo que está haciendo es derivar la sanción a un responsable. No es defendible. Ambas actuaciones de la Administración suponen sancionar. [Así, las SsAN 22/9/05 (recurso 324/05); de 2/4/09 (recurso 534/05); de 9/10/05 (recurso 254/05); y de 29/6/07 (recurso $n^{\circ} 141 / 04$ ), en las que se puede apreciar cómo la Audiencia Nacional en materia de responsabilidad ha venido derivando las sanciones solo en base ese principio de culpabilidad... habría dos acciones, la del que emite la factura y la del que deja que se la emitan. De ser así, o bien la receptora de las facturas es la víctima de tal acción, en cuyo caso no puede ser sancionada; o bien ha tenido parte en ello, y entonces ha de tenerse en cuenta su actuar globalmente considerado, y verse si estamos ante un medio o instrumento para cometer otra acción, ver si estamos ante un delito medial, ver si estamos ante un modo de graduar la sanción o de tipificar la infracción. Esto es lo que hace la Administración cuando se encuentra ante casos de facturas falsas tener en cuenta la circunstancia de la utilización de medios fraudulentos y agravar la sanción de dejar de ingresar. Pero sancionar ahora, de nuevo, no es posible, pues la conducta ya fue analizada, o debió serlo, en su totalidad. Así se desprende del artículo 3 del RD 2063/2004, Reglamento General del Régimen Sancionador, según el cual ha de hacerse una "calificación unitaria de la infracción». ...Así la STSJ de Cataluña, Sala de lo Contencioso-Administrativo, Sección $1^{\text {a }}$, núm. 1236/2009, de 10 diciembre, ponente don Emilio Aragonés Beltrán y la SAN de 5 de junio de 2000, SsTSJ de Castilla y León de Burgos, Sala de lo Contenciosoadministrativo, Sección 2a, de 15 Julio 2011, rec. 247/2010, y de 30 Septiembre 2011, rec. 246/2010. PUEBLA AGRAMUNT,N.; GALIANO ESTEVAN,J.: "La doble sanción al responsable en los casos de facturas falsas", Quincena Fiscal Aranzadi, núm. 18, 2012, BIB 2012 3065. Llamamos la atención sobre estos dos preceptos, que no por encontrarse en el Reglamento y no en la Ley dejan de ser cuestiones absolutamente fundamentales en la cualificación de la infracción. En el Reglamento sancionador se hacen continuas integraciones o interpretaciones de los conceptos legales, y así, el artículo 3 determina las condiciones que rigen en caso de concurso real de infracciones, supliendo con ello el silencio de la Ley, y los artículos 4 a 6 definen y reglamentan las circunstancias modificativas o agravantes, esto es, las 
cipio determina la interdicción de la duplicidad de sanciones administrativas y penales respecto de unos mismos hechos, pero conduce también a la imposibilidad de que, unos mismos hechos, sea valorado varias veces en el ámbito punitivo. Manifestación de tal criterio es lo dispuesto en el art. 180.1 de la LGT, por cuanto implica la imposibilidad de que una misma acción u omisión se aplique como criterio de graduación y como elemento de calificación de la misma infracción. Dicho planteamiento también es puesto de relieve en el Derecho punitivo por excelencia, el Derecho penal, que en su art. 67 del CP señala la inaplicabilidad de las circunstancias agravantes o atenuantes, a las que la ley ya haya tenido en cuenta al describir o sancionar una infracción, o a las que sean de tal manera inherentes al delito que sin la concurrencia de ellas no podría cometerse. Tal formulación da lugar a la regla de inherencia, ya sea expresa o tácita. La delimitación de las infracciones graves sobre la base de la utilización de medios fraudulentos reducidos -regla específica del $2^{\circ}$ párrafo del art. 191.3 de la LGT- también resulta infructuosa. Resulta difícilmente admisible que en tales elementos considerados como fraude, por la utilización de tales medios, no conlleven ocultación, a excepción de las menciones del apartado c) del art. 191.3 de la LGT. En base a lo razonado ${ }^{147}$ no existen las infracciones graves, salvo el supuesto anterior, pues originan una doble valoración del elemento de ocultación. Por un lado, como aspecto consustancial de la infracción base y; por otro lado, como circunstancia de calificación de la presente infracción grave.

Por último, debe considerarse que, en aquellas conductas en las que se ha ingresado menos de lo realmente debido a anomalías en la contabilidad, por ejemplo haberse contabilizado en el libro registro una cifra inferior de ventas, deberá entenderse que se ha cometido la infracción en el momento de la presentación de la declaración, y no en el momento en que se contabilizó de forma incorrecta ${ }^{148}$.

que cualifican la infracción o determinan la gravedad de la sanción, o qué son a efectos sancionadores las facturas, justificantes $\mathrm{u}$ otros documentos o soportes falsos, previsiones todas ellas más propias de la Ley que de la decisión de la propia Administración. NAVARRO SANCHÍS, F.J; URBANO CASTRILLO, E.: "El procedimiento sancionador", en la obra colectiva La deuda fiscal. Cuestiones candentes de Derecho Administrativo y Penal, edición núm. 1, Editorial LA LEY, Madrid, Octubre 2009, quien califica esto como una quiebra sustancial de la legalidad en materia sancionadora.

147 SÁNCHEZ HUETE, M.A.: “Elementos para un análisis...”, op. cit. págs.182183.

148 STSJ de Aragón de 25 de mayo de 1991. 


\section{Compatibilidades infractoras}

No se cometerán las infracciones de los artículos 198 y 199 LGT por no presentar o presentar incorrectamente al quedar dicho tipos subsumidos en los tipos de los artículos 191, 192, y 193 de la LGT ${ }^{149}$. El artículo $180.2 .2^{\circ}$ de la LGT $^{150}$ prevé la compatibilidad de las sanciones del artículo 191 con los artículos $194^{151}$ y 195 de la LGT ${ }^{152}$. En el caso de concurrencia entre la infracción del artículo 191.5 y 193.5 de la LGT, la del artículo 191.5 absorberá el desvalor de la preparatoria $^{153}$.

En resumidas cuentas, las compatibilidades del artículo 191 de la LGT son la limitada del artículo 194.1, por mor del artículo 194.2 LGT, y la del artículo 195 LGT $^{154}$, ex artículo 180 de la LGT, con la incompatibilidad implícita del artículo 195.3 LGT. El artículo 191 prevalecerá y absorberá las conductas de los artículos 193 LGT $^{155}$ -

149 SÁNCHEZ HUETE, M.A.: Las infracciones...op.cit.págs.158. y 159; Por entender que la cuantía dejada de ingresar es el resultado de adicionar al importe de la devolución obtenida indebidamente la cuantía total que hubiera debido ingresarse en la autoliquidación. MESTRE GARCÍA, E. y CERVANTES SÁNCHEZRODRIGO, C. J.: Guía de infracciones...op.cit. pág.165; Conforme a los arts. 16.3y 17.3 RGRST se prevé la incompatibilidad de los arts. 191 a 197 con los arts. 200 y 201, prevaleciendo aquéllos sobre éstos. AA.VV. (Coord. PELÁEZ MARTOS, J.M ${ }^{\mathrm{a}}$.): Todo procedimiento..op.cit.pág.1006.

150 Para HERRERA MOLINA el artículo muy probablemente resulte contrario a la regla punitiva que ha de presidir el castigo de varias infracciones consecuencia de un solo hecho (concurso ideal del art. 77 CP). AA.VV. (Dir. HERRERA MOLINA,P.M.): Factbook Fiscal, IEF, Thomson-Aranzadi, Navarra, 2004, pág.267.

151 En caso de que al comprobar la Administración la situación del obligado se concluyera que no sólo no existe derecho a obtener la devolución (art. 194) sino también se han dejado de ingresar cantidades (art. 191) al Erario, procederá aplicar ambas sanciones. ANÍBARRO PÉREZ, S. y SESMA SÁNCHEZ,B.: Infracciones... op.cit.págs. 125 y 126.

152 Debemos considerar el régimen de deducciones en sanciones ulteriores que regula el art. 195.3 LGT. El propio Consejo de Estado criticó dicha reducción en su Dictamen de 22 de mayo de 2003, en el que aconsejó a bien la reducción de la sanción o bien la deducción total; En base a ello algún autor considera que por el principio non bis in idem solo se ha de poner una infracción y no la reducción proporcional de una sobre la otra. SÁNCHEZ HUETE,M.A.: Las infracciones... op.cit.pág.216.

153 Así lo expone PALAO TABOADA,C.: Comentario...op.cit.pág.556.

154 STSJ Castilla-León, Valladolid núm. 1344/2016 de 7 de octubre de 2016; La solicitud incorrecta de una devolución indebida y la posterior sanción por dejar de ingresar en plazo la deuda tributaria, derivada de ésta, son compatibles, no vulnerándose el principio de «non bis in idem" (STSJ Canarias, Las Palmas de Gran Canaria, Sala de lo Contencioso-Administrativo, Sec. 1. $\left.{ }^{a}, 24.10 .2008\right)$.

155 Para calificar una infracción como muy grave por la utilización de medios fraudulentos hay que atender a las circunstancias de la conducta de la que deriva la misma, independientemente de que debido a la propia mecánica liquidatoria del impuesto dichas circunstancias se hayan producido en un momento anterior al de 
por mor del artículo 191 LGT $^{156}$-, y la de los artículos 194.2, 196 y 197 LGT, puesto que así lo indican los mismos. Por último, el artículo 191 cede a favor del artículo 170.2 de la Ley del IVA y del 63.5 de la Ley del IGIC.

Como conclusión, el supuesto del artículo 191 LGT se corresponde mutatis mutandis con el de la letra a) del artículo 79 de la LGT de 1963, consistente, como es sabido, en la omisión del ingreso en los tributos con autoliquidación. Se trata de una infracción de omisión impropia, ya que se ordena evitar un resultado, esto es, no es suficiente el no hacer (no presentar una autoliquidación) sino que además ha de producirse una falta de ingreso total o parcial de la deuda, por lo que en principio se puede decir que la infracción se consuma en el momento en el que finaliza el plazo voluntario de ingreso $^{157}$, esto es, cuando se lesiona la recaudación que es el bien jurídico protegido, y ello con independencia de las circunstancias que concurran, que determinarán que pueda ser calificada la infracción como leve, grave o muy grave.

Un caso que no podemos dejar de comentar es el del régimen de infracciones y sanciones, en lo atinente al incumplimiento de la obligación de informar sobre los bienes y derechos situados en el ex-

comisión de la infracción. En el caso concreto, el interesado no había ingresado en sus declaraciones-liquidaciones cantidad alguna por ninguno de los períodos trimestrales comprobados. La autoliquidación del primer trimestre del ejercicio 2009 parte de una cantidad a compensar procedente de 2008; en ese trimestre se omite el registro de una factura con IVA repercutido de 22.196,11 euros, resultando la autoliquidación a compensar, cuando lo que procedía era un ingreso de 17.187,55 euros. En el 4º trimestre de 2010 se solicita una devolución de 5.008,56 euros (que se devuelve). Ambas cifras suman los 22.196,11 euros de IVA repercutido no registrado en 2009. Esos hechos significan la comisión de dos infracciones: artículos 191.1 LGT (dejar de ingresar en el 1er Trim/2009) y 193.1 LGT (obtener devoluciones indebidamente en el $4^{\circ}$ Trim/2010); siendo calificadas por la Inspección, ambas infracciones, como muy graves por la utilización de medios fraudulentos (anomalías sustanciales en la contabilidad o libros registros), siendo la mecánica liquidatoria la que traslada parte del efecto de la falta de registro de la factura en $2009 \mathrm{al} 4^{\circ} \mathrm{Trim} / 2010$. De acuerdo con las circunstancias de este caso, es la omisión del registro de la factura en el 1er trim/2009 (medio fraudulento), la que provoca, también la infracción de 2010, por lo que procede igualmente la calificación de muy grave la infracción por la devolución indebidamente derivada obtenida en la autoliquidación del $4^{\circ}$ trim/2010 (RTEAC 21.1.2016).

156 Vulnera la administración la LGT al aplicar conjuntamente la sanción por dejar de ingresar y por obtener indebidamente devoluciones, cuando expresamente no lo permite (STSJ Canarias, Las Palmas de Gran Canaria, Sala de lo ContenciosoAdministrativo, Sec. 1. $\left.{ }^{\mathrm{a}}, 3.7 .2009\right)$.

157 Se posiciona así la legislación utilizando el momento del vencimiento de la obligación tributaria, a diferencia del momento de su exigibilidad. BAYONA DE PEROGORGO, J.J.; SOLER ROCH,M.T.: Materiales de Derecho Financiero, Compás, Alicante, 2010, pág. 310. 
tranjero, se regula en el apartado 2 de la disposición adicional decimoctava de la $\mathrm{LGT}^{158}$, estando constituido el tipo por no presentar en plazo y presentar de forma incompleta, inexacta o con datos falsos las declaraciones informativas sobre bienes y derechos situados en el extranjero, si bien también se tipifica la presentación de las mismas por medios distintos a los electrónicos, informáticos y telemáticos en aquellos supuestos en que hubiera obligación de hacerlo por dichos medios. Las anteriores infracciones serán muy graves e incompatibles con las establecidas en los artículos 198 y 199 y su incumplimiento, ya afecte a cuentas en entidades de crédito, a títulos, activos, valores, derechos, seguros y rentas o a bienes inmuebles y derechos sobre los mismos situados en el extranjero se sanciona con una multa pecuniaria fija de 5.000 euros por cada dato o conjunto

158 Como interpretación de dicha disposición, debemos reproducir la contestación a la Consulta Vinculante 1434-17, de 6.6.2017, que, por lo que nos atañe conviene reproducir en parte: una interpretación que resulte coherente con la norma vigente aplicable en el contexto específico que nos ocupa, integradora de la finalidad y espíritu que guían el conjunto formado por el artículo 27 y la disposición adicional decimoctava de la LGT así como por la disposición adicional primera de la Ley 7/2012 y el artículo 39.2 de la LIRPF, lleva a la conclusión de la admisibilidad de que el obligado tributario pueda regularizar voluntariamente la ganancia patrimonial no justificada a que se refiere el artículo 39.2. Dicha coherencia exige, por otra parte, y de nuevo tomando como referencia ineludible la especialidad que se configura en el artículo 39.2 de la LIRPF, y muy concretamente por lo que ahora toca, en su párrafo primero, que la regularización voluntaria del incumplimiento que está en el fondo del precepto solo produzca los efectos jurídicos que le son propios, en ese contexto normativo específico, si se declara la ganancia patrimonial no justificada mediante la presentación de una autoliquidación extemporánea por el IRPF correspondiente al ejercicio más antiguo entre los no prescritos susceptible de regularización en el momento de la presentación de la citada autoliquidación complementaria, salvo que, conforme a lo dispuesto en la disposición adicional segunda de la Ley 7/2012, corresponda imputar la ganancia patrimonial no justificada a un período posterior. En todo caso, debe recordarse que no existirá ganancia patrimonial no justificada por la parte de los bienes o derechos que hubieran sido adquiridos tanto con rentas declaradas en plazo como con rentas declaradas mediante la presentación, dentro del plazo de prescripción, de una autoliquidación complementaria extemporánea sin requerimiento previo. La regularización voluntaria de la obligación tributaria material principal a través de una autoliquidación extemporánea en los términos expuestos, y particularmente en las condiciones señaladas en el párrafo anterior, permitiría, por aplicación de lo dispuesto en el artículo 27 de la LGT, la no aplicación de la sanción regulada en la disposición adicional primera de la Ley 7/2012, aplicándose el recargo por extemporaneidad que corresponda de acuerdo con el citado artículo 27 de la LGT. Por último hay que precisar que, si bien la interpretación normativa que realiza este Centro de Directivo ha sido referida al artículo 39.2 de la LIRPF, la misma resulta extrapolable en relación con lo dispuesto en el artículo 121.6 de la Ley 27/2014, de 27 de noviembre, del Impuesto sobre Sociedades (artículo 134.6 del Texto Refundido de la Ley del Impuesto sobre Sociedades, aprobado por el Real Decreto Legislativo 4/2004, de 5 de marzo, introducido por la reiterada Ley 7/2012 con análogo objetivo). 
de datos ${ }^{159}$ referidos a un mismo bien o derecho que hubiera debido incluirse en la declaración o hubiera sido aportado de forma incompleta, inexacta o falsa, con un mínimo de 10.000 euros, por lo que la sanción es desproporcional cuando el incumplimiento de la obligación de informar sólo afecte a un bien o derecho. Al ser compatible esta infracción con la infracción por dejar de ingresar derivada del incremento no justificado de patrimonio o de la presunción de rentas, se plantea un problema de proporcionalidad, pues como afirma Falcón y Tella ${ }^{160}$ resulta completamente desproporcionado, tanto en lo que se refiere a las sanciones del apartado 2 de la disposición adicional decimoctava de la $\mathrm{LGT}^{161}$ como en relación con las sanciones del 150 por cien de la renta presunta, que ni siquiera se declara incompatible con las anteriores. Dicha compatibilidad nos merece los siguientes comentarios: 1. La calificación legal de ambas infracciones de "muy grave" presupone que las conductas del presunto infractor son dolosas, por ello, si el sujeto sancionado acredita que sólo incurrió en culpa o negligencia deben anularse las sanciones impuestas, más bien, si el instructor del expediente no prueba el dolo del sujeto infractor no podrá imponer sanción alguna, a menos que contravenga los principios de culpabilidad y proporcionalidad, por ejemplo, presentar el modelo 720 fuera de plazo sólo podrá ser sancionado si se acredita por la Hacienda pública que el contribuyente incurrió en dolo, de la misma forma que no se podrá sancionar por el incremento de patrimonio no justificado o por la renta presunta, aunque el presunto sujeto infractor haya incurrido en culpa o negligencia. 2. En lo atinente a la sanción por dejar de ingresar, la imprescriptibilidad y la presunción iuris et de iure tendrían poca eficacia en el ámbito del derecho penal porque, primero, los delitos prescriben en función de la pena que lleven aparejada -10 años, cuando la pena máxima señalada por la ley sea prisión por más de 5 años y que no exceda de 10 (CP Art. 131.1)-, y segundo, la prueba de presunciones no desvirtúa la presunción de inocencia.

159 Concepto desarrollado por el apartado 7 del artículo 42 ter del Real Decreto 1065/2007.

160 FALCÓN Y TELLA, R.: “El modelo 720(I): especial referencia a la contabilidad de las personas físicas y a las sociedades sin personalidad”, Quincena Fiscal, no 11/2013.

161 La omisión de algún elemento no esencial de la declaración, pero que la haga incompleta no debería ser calificado como un comportamiento muy grave si el dato omitido no tiene especial relevancia tributaria. PEDREIRA MENENDEZ, J.:"La obligación de información sobre bienes y derechos situados en el extranjero", Quincena Fiscal, n 4/2013. 
La citada ineficacia también se trasladará al ámbito sancionador tributario, pues como afirma Simón Acosta ${ }^{162}$ las ganancias de patrimonio no justificadas y las rentas presuntas se imputan temporalmente a un período impositivo en que todavía no son aplicables las consecuencias jurídicas en ellos previstas, en similares términos, Rozas Valdés ${ }^{163}$ afirma que estamos ante un grado de retroactividad máxima de la ley tributaria -afecta a situaciones jurídicas pretéritas ya consolidadas- que el Tribunal Constitucional podría considerar contrario a las exigencias propias del principio de seguridad jurídica, por cuanto la original creatividad con la que el redactor de la norma ha pretendido que las cosas no son lo que son, sino lo que la Administración quiere que sean. 3. La duplicidad de sanciones y la elevada cuantía de las mismas, junto con su tributación a tipos marginales, es contraria a la sentencia del Tribunal de Justicia de la Unión Europea de 16 de julio de 2015, ya citada, por lo que se abre una importantísima nueva vía de control de la potestad sancionadora de la Hacienda pública, en su vertiente del principio de proporcionalidad, sin olvidar su carácter confiscatorio. Al respecto, la Comisión Europea ha iniciado un procedimiento de infracción a España por incumplimiento del Derecho Comunitario, ante las denuncias recibidas sobre este régimen sancionador específico, desproporcionado e imprescriptible.

\section{Conclusiones}

- Debemos de considerar a la infracción consistente en dejar de ingresar la deuda tributaria que debiera resultar de una autoliquidación, como infracción de resultado que causa perjuicio económico a la recaudación de la Hacienda Pública.

- La comisión -por omisión- de esta infracción se produce en caso de falta de ingreso de la totalidad o parte de la deuda tributaria que debería resultar de una correcta autoliquidación del tributo dentro de los plazos reglamentariamente establecidos.

— La fecha de ingreso del sujeto pasivo es aquélla en la que ingresa en la entidad colaboradora, independientemente de que

162 SIMÓN ACOSTA, E.: "Declaración de bienes en el extranjero: un piélago de irracionalidad e inconstitucionalidad", Actualidad Jurídica Aranzadi, no 898/2015.

163 ROZAS VALDÉS, J.A.: "El régimen tributario y sancionador específico del patrimonio ubicado en el extranjero", Revista Técnica Tributaria, n 109/2015.

(C) UNED. Revista de Derecho UNED, núm. 26, 2020 
se haya abonado inmediatamente en la cuenta abierta por la Administración acreedora.

- El plazo de prescripción de la responsabilidad derivada de la infracción tributaria presuntamente cometida se iniciará a partir del día siguiente al que finalice el plazo para autoliquidar la deuda.

- No es posible sancionar por la mera referencia al resultado, sin motivar específicamente de donde se colige la existencia de culpabilidad. La infracción exige de la apreciación de la culpabilidad en la conducta del sujeto infractor, sin perjuicio que el sujeto infractor pueda esgrimir que ha efectuado una interpretación razonable de la norma, aunque esta pudiera resultar errónea, lo que deberá ponderarse caso a caso.

- Respecto del ejercicio de la carga probatoria, sólo cuando la Administración ha razonado, en términos precisos y suficientes, en qué extremos basa la existencia de culpabilidad, procede exigir al acusado que pruebe la existencia de una causa excluyente de la responsabilidad.

- Quedan exonerados de sanción por la infracción cometida cuando se regularice la situación mediante la presentación -regularizatoria- de declaración o autoliquidación extemporánea sin requerimiento previo de la Administración tributaria o cuando se presente correctamente la correspondiente autoliquidación en plazo con resultado a ingresar sin realizar el ingreso de todo o parte de la deuda que de la misma resulta.

- La regularización voluntaria con ingreso del artículo 27 LGT entendemos que no excluye la infracción, que siempre existirá por mor del artículo $27.2^{\circ} \mathrm{LGT}$, sino la sanción.

- En los casos de incoación de procedimiento sancionador sin regularización previa a la notificación de la incoación de alguno de los procedimientos a que refiere el artículo 27.1.1 ${ }^{\circ} \mathrm{LGT}$, podrá aprovecharse de dicha circunstancia el sujeto infractor para exonerarse de responsabilidad por infracción tributaria, extinguiéndola.

- La regularización encubierta del artículo 191.6 de la LGT concede un cierto beneficio al infractor cual es considerar leve la infracción, pero no exime de modo íntegro de la responsabilidad infractora. 
- Con la finalidad de evitar un enriquecimiento injusto a la Administración, se impide la exigencia al retenedor de las retenciones no aplicadas en aquellos casos en los que se haya producido ya una regularización por parte del perceptor de las rentas en su declaración anual. Para poder admitir una eventual exigencia administrativa de las retenciones al retenedor se impone a la Administración la carga de la prueba de que ese doble pago no se ha producido, no considerándose como válida una mera actuación pasiva de aquélla en virtud de la cual se limite únicamente a considerar que ese doble pago o cobro no se ha producido.

- El incumplimiento de ingresar pagos a cuenta, en la vía administrativa, no constituye infracción tributaria, pese a estar correctamente sancionado, sin embargo, dicho incumplimiento sí es susceptible de constituir delito contra la Hacienda Pública, cuando el retenedor haya incurrido en dolo y la cuota defraudada supere los $120.000 €$, ex artículo 305 del Código Penal.

- En relación a los pagos fraccionados si una persona que no realiza los pagos fraccionados (art. 23.1 LGT) dentro de los plazos que tiene establecidos para hacerlo, es evidente que si luego no se los deduce cuando presenta la declaración final o recapitulativa de todo el período, significa que los está ingresando en ese momento, en tanto en cuanto no se los está deduciendo. Se trataría, a nuestro juicio, de un ingreso extemporáneo realizado sin requerimiento previo, al que debe aplicársele el recargo del artículo 27 de la LGT.

- Opta el legislador por subsumir la infracción consistente en obtener indebidamente devoluciones en la infracción consistente en dejar de ingresar en plazo la deuda que debiera haber resultado de la autoliquidación, otorgándoles un tratamiento único.

- Acontece la «regularización voluntaria encubierta» cuando no se cumple alguno de estos dos requisitos, que se identifique expresamente el período impositivo de la liquidación a que se refiere y que contenga únicamente los datos relativos a ese período.

- Los únicos pagos fraccionados que pueden suponer la comisión de una infracción de dejar de ingresar son aquellos que no se ingresan dentro de sus plazos reglamentarios y que, antes de realizarse la liquidación definitiva, final o recapitulativa. En el caso de que ni se realicen los pagos fraccionados ni se presente 
la declaración definitiva o final del período, no ingresándose, por tanto, cantidad alguna en ningún momento, habría que entender que se ha producido la infracción del artículo 191 LGT.

- Se agravará la infracción cuando además exista, según el artículo 4.1 del RGRST, ocultación de datos a la Administración tributaria, que se dará cuando se produzcan las circunstancias previstas en el artículo 184.2 de la Ley 58/2003, de 17 de diciembre, General Tributaria, aún cuando la Administración tributaria pudiera conocer la realidad de las operaciones o los datos omitidos por declaraciones de terceros, por requerimientos de información o por el examen de la contabilidad, libros o registros y demás documentación del propio sujeto infractor.

- Existirá ocultación en todo caso, cuando se haya dejado de presentar la declaración -aún cuando estos datos obren ya en poder de la Administración- y también cuando se haya presentado una declaración con datos omitidos o falseados en una cuantía tal que la deuda derivada de la ocultación sea superior al 10 por 100 del total de la deuda dejada de ingresar. La LGT ha dejado claro que puede existir infracción sin ocultación, es decir, que la ocultación no forma parte del tipo infractor.

- No cabe considerar ausencia, en todo o en parte, de contabilidad cuando no afecte a la exacción del tributo, siempre que pueda realizarse en virtud de los documentos aportados por el propio obligado, de modo que dicha circunstancia vendrá ya contenida en la propia infracción consistente en dejar de ingresar la totalidad o parte de la deuda tributaria, siendo lo procedente calificar la infracción como de omisión por la presentación inexacta.

- La infracción base requiere de ocultación para su afirmación, de ahí, que no podrá volverse a apreciar dicho aspecto como elemento que califique tal infracción.

- Debe considerarse que, en aquellas conductas en las que se ha ingresado menos de lo realmente debido a anomalías en la contabilidad, por ejemplo haberse contabilizado en el libro registro una cifra inferior de ventas, deberá entenderse que se ha cometido la infracción en el momento de la presentación de la declaración, y no en el momento en que se contabilizó de forma incorrecta. 